University of Louisville

ThinkIR: The University of Louisville's Institutional Repository

Electronic Theses and Dissertations

$12-2020$

\title{
Student perceptions of personalized learning in a rural school district.
}

Kathryn M. House

University of Louisville

Follow this and additional works at: https://ir.library.louisville.edu/etd

Part of the Curriculum and Instruction Commons

\section{Recommended Citation}

House, Kathryn M., "Student perceptions of personalized learning in a rural school district." (2020). Electronic Theses and Dissertations. Paper 3566.

https://doi.org/10.18297/etd/3566

This Doctoral Dissertation is brought to you for free and open access by ThinkIR: The University of Louisville's Institutional Repository. It has been accepted for inclusion in Electronic Theses and Dissertations by an authorized administrator of ThinkIR: The University of Louisville's Institutional Repository. This title appears here courtesy of the author, who has retained all other copyrights. For more information, please contact thinkir@louisville.edu. 


\title{
STUDENT PERCEPTIONS OF PERSONALIZED LEARNING IN A RURAL SCHOOL DISTRICT
}

\author{
Kathy House \\ B.S., Indiana University, 1987 \\ M.Ed., Indiana State, 2000 \\ Ed.S., University of Louisville, 2012
}

\author{
A Dissertation \\ Submitted to the Faculty of the \\ College of Education and Human Development of the \\ University of Louisville \\ in Partial Fulfillment of the Requirements \\ for the Degree of
}

Doctor of Education in Educational Leadership and Organization Development

Department of Educational Leadership, Evaluation, and Organizational Development University of Louisville Louisville, Kentucky

December 2020 
Copyright 2020 by Kathy House

All Rights Reserved 



\title{
STUDENT PERCEPTIONS OF PERSONALIZED LEARNING IN A RURAL SCHOOL DISTRICT
}

\author{
By
}

\author{
Kathy House \\ B.S., Indiana University, 1987 \\ M.Ed., Indiana State, 2000 \\ Ed.S., University of Louisville, 2012
}

A Dissertation Approved on

October 26, 2020

by the following Dissertation Committee:

\begin{tabular}{c}
\hline Dissertation Chair \\
W. Kyle Ingle, Ph.D. \\
\hline Deborah Powers, Ed.D. \\
\hline
\end{tabular}

B. Keith Davis, Ed.D.

Douglas Stevens, Ph.D. 


\section{DEDICATION}

This dissertation is dedicated, in part; to the students I have served across my 32year career in education. I almost feel as though I owe an apology to the students in the beginning of my career, as I have learned so much and can now reflect on the many ways in which I failed to meet their needs. From the beginning of my career, I have held on to the belief, "If you believe, you can achieve". I have also put great value on my continued growth professionally in order to better meet the needs of my students.

This dissertation is also dedicated to three generations of educators in my family. I am proud to serve this profession in the footsteps of my grandmother, mother, and aunt; and concurrently with four of my first cousins. 


\section{ACKNOWLEDGEMENTS}

I would like to thank Dr. Deborah Powers for her constant support, guidance, and time. You have served as a mentor and cheerleader when I needed it. Thank you to Dr. Kyle Ingle for his ability to push me through his critical and thoughtful feedback that enabled me to convey my study in a manner that rose above what I ever thought possible. Dr. Doug Stevens for going out of his way to provide insight into the process of the structured ethical reflection, as well as a systematic and analytic process in which to analyze my qualitative data. This enabled me to delve deep into my data and to "see" what it was telling me. Finally, to Dr. Keith Davis, for providing me the opportunity to see myself as a leader and believing in me to hire me as a principal. That decision, led me on the trajectory to achieve this process.

I am also so appreciative of my Cohort family at the University of Louisville. We started on this journey in January of 2018 full of enthusiasm and optimism. We prevailed through statistics together, and while we have different timelines for completion, we have served as cheerleaders and great support to each other. I could not have done it without you!

Lastly, but most importantly, I would like to thank my family. My husband Jay, daughters Morgan and Elizabeth, son Mack, and grandson Beau. You have been my 
biggest cheerleaders and have put up with the many trials and tribulations of this process.

Thank you for believing in me! 


\section{ABSTRACT \\ STUDENT PERCEPTIONS OF PERSONALIZED LEARNING IN A RURAL SCHOOL DISTRICT \\ Kathy House}

October 26, 2020

This case study explored student perceptions of the implementation of personalized learning as a means of supporting student engagement and improved student outcomes. A review of research revealed a mismatch between the current instructional pedagogy utilized and the needs identified by the workforce. The world has evolved rapidly while education has slowly evolved, creating an ever-increasing relevance gap for students. We have transitioned to a global society and innovations in technology have led the way. Today's workforce requires students to have soft skills and competencies to be able to think critically, problem solve, develop resiliency, be innovative and creative, communicate effectively, collaborate effectively, and lead for change. These postsecondary skills require educators to think differently about the practices utilized in schools to prepare students for jobs that do not yet exist.

The purpose of personalized learning is to empower students and to offer a student-centered environment designed to meet the varying needs of today's learners. While the body of research on personalized learning continues to grow, there is a lack of research on the perceptions and roles students play in the implementation process 
In order to understand the importance of student agency, voice, and choice in the student experience, this case study explored student perceptions of personalized learning.

I drew upon data collected from three sources: a student survey, student interviews, and documents pertaining to district- and school-level curriculum and instruction. The interviews provided insight into each student's unique perspective on their experience throughout the implementation process of personalized learning. As I reviewed the comments aligned with the selective codes and reflected as to how they answered the research questions, the transition students have experienced from the traditional to the personalized learning approach is evident.

This study shows that successful implementation of personalized learning is heavily dependent on the capacity of the teachers involved in the implementation process. Students indicated the need to address potential implementation issues; most notably, the inconsistencies and differences among teachers throughout the implementation process. This points directly to implications for practice to mitigate these differences and to foster a more inclusive and productive learning environment for all students. Oftentimes we do not give students the credit they deserve for understanding the impact of the classroom and school environment on their learning process. Students are extremely intuitive as demonstrated through their responses, and this study reveals the importance of including their voice in the process of improving the learning experience for all students. 


\section{TABLE OF CONTENTS}

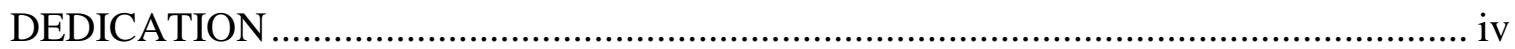

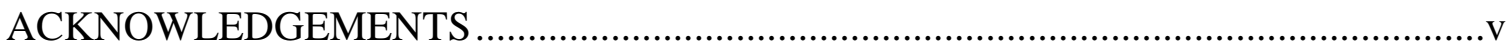

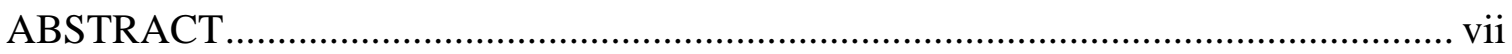

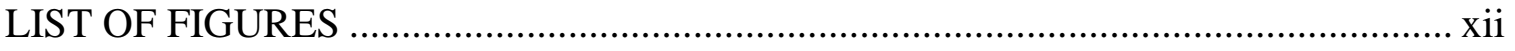

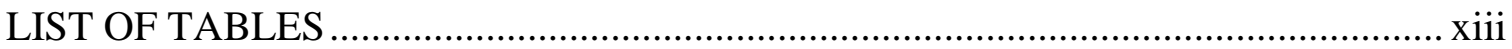

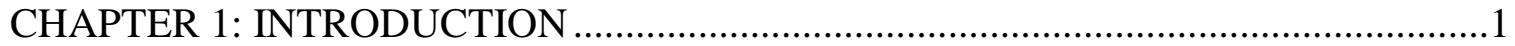

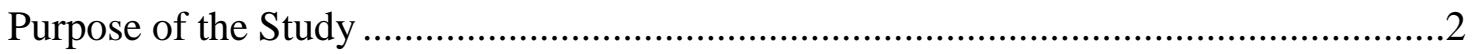

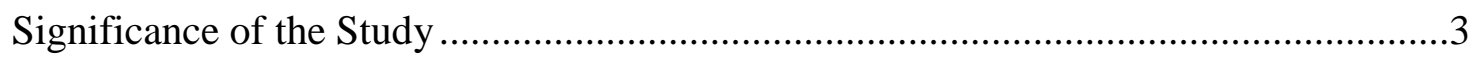

Theoretical Underpinnings and the Selection of Methodology ..................................5

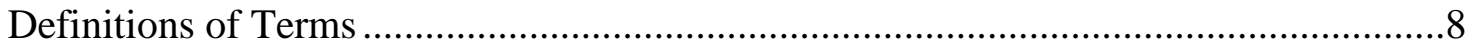

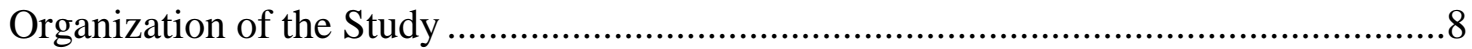

CHAPTER 2: LITERATURE REVIEW …...............................................................

A Brief Historical Primer of the U.S. Educational System......................................11

The Changing Role of the Teacher and the Student .................................................15

Student Engagement and the Role of Student Agency ...........................................17

Competency Based Learning ..............................................................................19

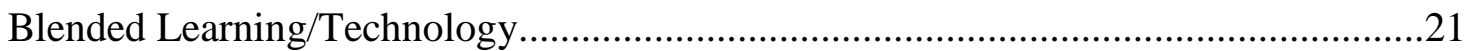

Personalized Learning Defined-Multiple Perspectives ..........................................24

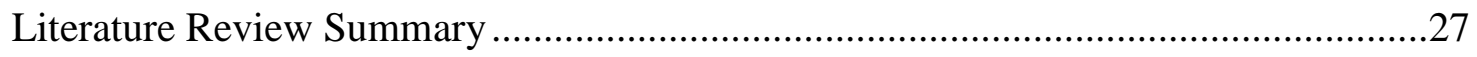

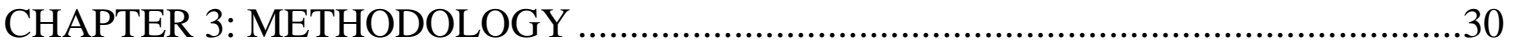

Research Methods and Design—Qualitative Case Study .........................................31

Strengths and Limitations of Qualitative Case Studies..............................................32

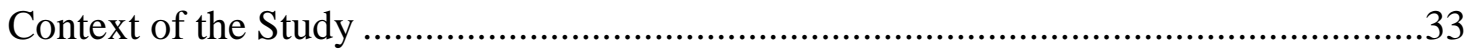

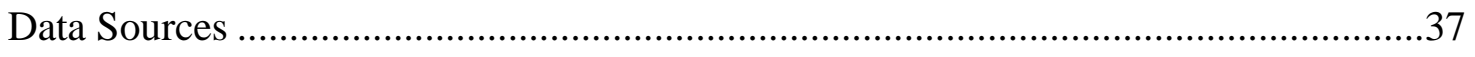

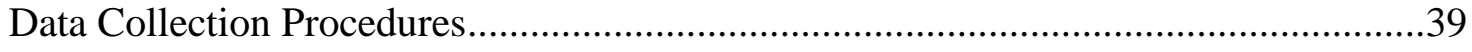

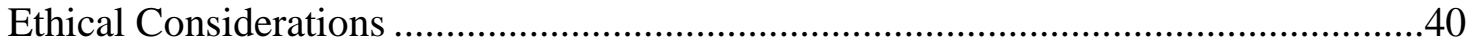




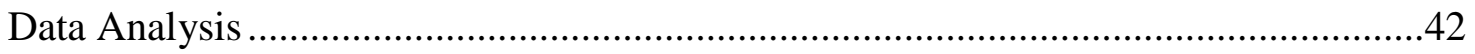

Process for Exploring Researcher Positionality .......................................................43

Strategies for Ensuring Credibility, Transferability, Dependability, and

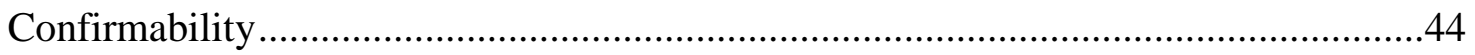

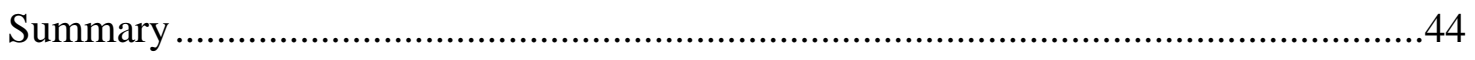

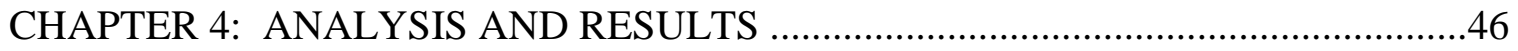

An Exploration of Researcher Positionality .........................................................47

An Overview of Data Sources and Analytical Strategies ........................................49

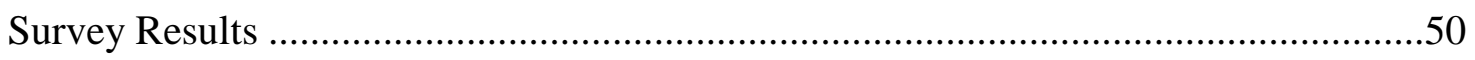

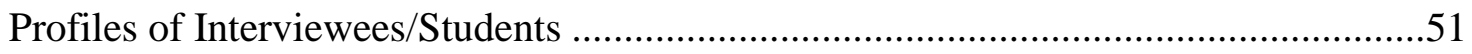

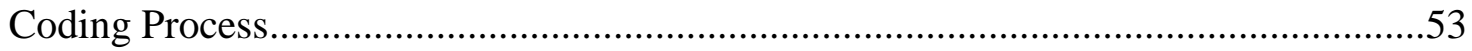

Student Perceptions of Personalized Learning and the Student Experience..................54

Student Perceptions of Their Role in Personalized Learning .....................................60

Student Perceptions of Teachers in Personalized Learning ......................................67

Student Perceptions of Peers in Personalized Learning ...........................................74

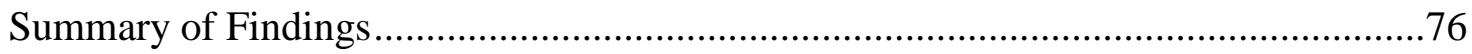

CHAPTER 5: SUMMARY OF FINDINGS AND IMPLICATIONS ...........................78

RQ 1: Student Perceptions of Personalized Learning and their Overall Student

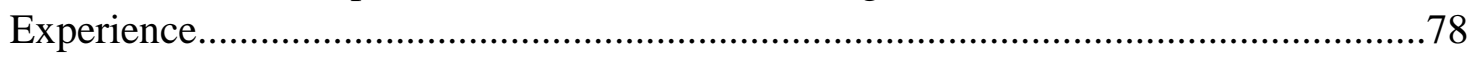

RQ 2: Student Perceptions of Changes in their Role in the Learning Experience ........81

RQ 3: Student Perceptions of the Teacher in the Personalized Learning Initiative.......83

RQ 4: Student Perceptions of their Classmates in the Personalized Learning

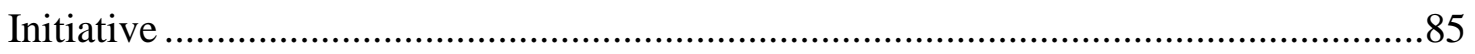

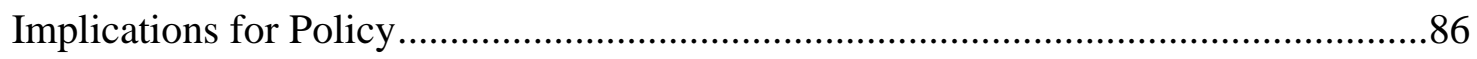

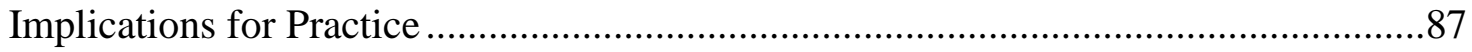

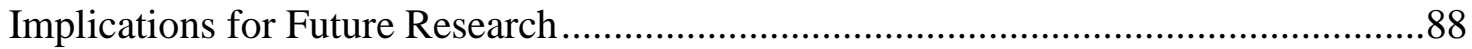

REFERENCES ............................................................

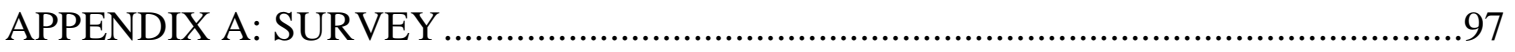

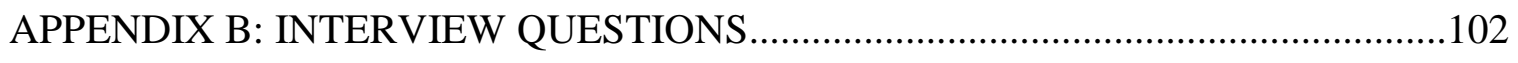

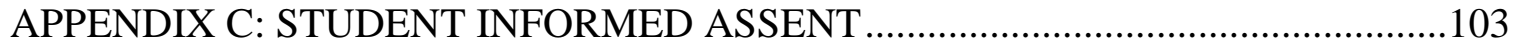


APPENDIX D: PARENT/GUARDIAN INFORMED CONSENT 105

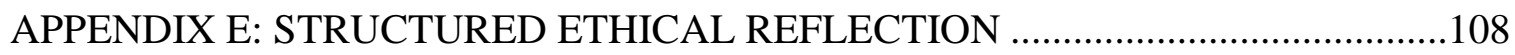

APPENDIX F: STRATEGIC PLAN/GRADUATE PROFILE ...................................109

APPENDIX G: WALKTHROUGH DOCUMENTS .............................112

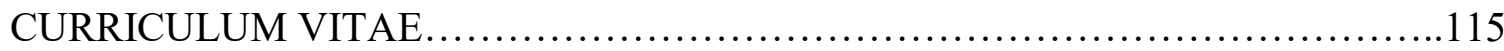




\section{LIST OF FIGURES}

Figure 1. Yin's (2018) Typology of Case Study Designs .............................................32

Figure 2. Yin's (2018) Design Versus Data Collection .................................................39 


\section{LIST OF TABLES}

Table 1. Enrollment Trends, Trimble County School District and Trimble County Junior/Senior High School, 2016-2017 to 2020-2021 ..................................................34

Table 2. Demographics, Trimble County Junior/Senior High School (2018-2019).........34

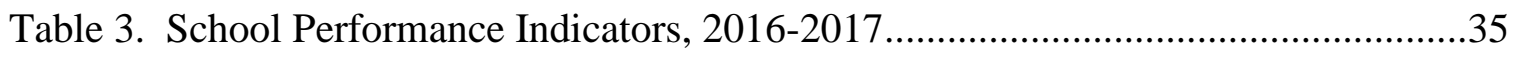

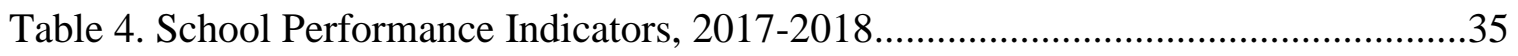

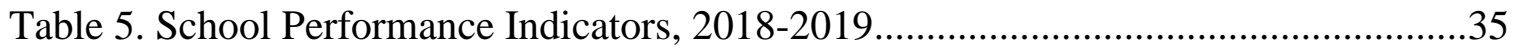

Table 6. Data Sources Aligned to Research Question ................................................50

Table 7. Student Survey Top Four Responses ..........................................................51

Table 8. Demographics of Student Interviewees ............................................................52

Table 9. Demographics of Individual Students Interviewed ......................................52

Table 10. Selective Codes Alignment to Research Questions ..........................................54

Table 11. Strategies to Achieve Academic Excellence Aligned to Selective Codes........66

Table 12. Walkthrough Tools Aligned to Selective Codes............................................73 


\section{CHAPTER 1: INTRODUCTION}

Education policy and politics scholars in the United States noted the historical dominance of local policy actors, such as school boards, superintendents, principals, local businesses, and mayors in shaping education policy and practice (Shipps, 2006; Stone, Henig, Jones, \& Pierannunzi, 2001). However, state and federal governments challenged the power of local education actors in education politics and policies, eventually dominating educational policymaking. Federal education policies, most notably, the No Child Left Behind Act of 2001 (NCLB) and the Every Student Succeeds Act of 2015 (ESSA) dramatically affected the delivery of public education at the state, district, and classroom levels. President Obama signed the Every Student Succeeds Act (ESSA) on December 10, 2015. Like NCLB before it, ESSA serves as the most recent reauthorization of the 50-year-old Elementary and Secondary Education Act (ESEA), evidence of the federal government's longstanding commitment to equal opportunity for all students. Additionally, the American Recovery and Reinvestment Act of 2009 (ARRA) provided additional incentives to U.S. states and districts for implementing reforms desired by the federal government.

In spite of the expanded role of federal and state government in education, instructional practices and the structure of many schools in the United States have changed relatively little over the last century. While there have been a number of changes and reforms, including the addition of charter schools and career academies, many classrooms remain traditional in nature. Indeed the emphasis on standards, assessment, and accountability in federal and state policy have reinforced the emphasis on the independent absorption of information by students with a focus on what Bloom (1956) would have classified as the lower levels of his taxonomy of learning 
goals - knowledge and comprehension levels. The greater emphasis on basic literacy and numeracy standards, assessment, and accountability led to teachers devoting more classroom time to tested subjects and employing strategies that teach to the test (Dee, Jacob, \& Schwartz, 2013; Murnane \& Papay, 2010).

When one thinks about how society and the needs of the workforce have changed, stakeholders begin to question the public education system and its delivery. One proposed reform is through the pedagogy of personalized learning. The purpose of personalized learning is to empower students and to offer a student-centered environment designed to meet the varying needs of today's learners. Taylor and Parsons (2011) provide research evidence that engaging students in the learning process increases their attention and focus, motivates them to practice higher-level critical thinking skills, and promotes meaningful learning experiences. Instructors who adopt a student-centered approach to instruction increase opportunities for student engagement, which then helps everyone more successfully, achieve the learning objectives. Today's workforce requires students to have soft skills and competencies to be able to think critically to problem solve, have resiliency, be innovative and creative, communicate and collaborate effectively, and lead for change. These post-secondary skills require educators to think differently about the practices we utilize to prepare students for jobs that do not yet exist. In order to meet the needs of what political, business, and cultural leaders from across the globe are referring to as the fourth industrial revolution (World Economic Forum, 2016), it is incumbent on educators to transform the school experience for today's youth.

\section{Purpose of the Study}

The purpose of this case study was to explore the implementation of personalized learning in a rural secondary school and the perceptions of the students who experienced this 
instructional strategy. The context for this study was Trimble County Junior/Senior High School, the only secondary school in the Trimble County School District. I selected this school and district purposively, as it implemented personalized learning in 2018. There are four research questions guiding this study with the first serving as an overarching driving question and the subsequent three delving into the impact on the student experience.

RQ 1: What are student perceptions of personalized learning and their overall student experience?

RQ 2: How have student perceptions of their role in their own learning experiences changed because of the personalized learning initiative?

RQ 3: How did student perceptions of the role of the teacher in their own learning experiences change because of the personalized learning initiative?

RQ 4: How did student perceptions of the role of their classmates in their own learning experiences change because of the personalized learning initiative?

\section{Significance of the Study}

Schools and districts throughout the United States are increasingly turning to personalized learning as a way to meet the diverse interests, needs, abilities, and aspirations of their students, and view it as a promising mechanism for raising academic achievement (Bingham, Pane, Steiner, \& Hamilton, 2018); Sykes, Decker, Verbrugge, \& Ryan, 2014). Prior research of this pedagogical approach revealed nuances of key terms used in K-12 education related to personalized learning, blended learning, and competency-based education.

Furthermore, extant research sought to understand how these ideas integrate in order to transform into new learning models that are student-centered. Qualitative studies explored parental 
influence on academic motivation and understanding the conditions that may promote optimal motivation for students. Students prosper when the home environment supports academics and shared beliefs and attitudes regarding school (Verna, 2007). Qualitative studies have also explored the impetus for change in instructional pedagogy and practices (The New Teacher Network, 2018). Quantitative studies examined student perceptions of their instructors and the relationships between personalized learning and student achievement (Zeiser, Scholz, \& Cirks, 2018). As an increasing number of schools explore personalized learning, there is an urgent need for empirical research in the area of student perception and their experience as a student. This qualitative case study aims to understand the student experience shared in a survey and follow up interviews in order to inform practitioners involved in this potentially transformational instructional pedagogy. The school itself, as well as educators and curriculum developers who need to increase understanding of the student perceptions of personalized learning to facilitate student engagement, can use this case study to explore the opportunity to increase student agency, voice, and engagement in the learning process.

Within the literature, there is a specific gap in the research in regard to the student perspective and perceptions of the experience and what it does or does not do to improve the learning process and their engagement in that process (Fielding, 2006; Netcoh, 2017a, 2017b). Netcoh's research studies (2017a, 2017b) represent some of the few studies that explore student perceptions of personalized learning. He states that, "Given this study's findings are based on one middle school team's experiences, however, additional research should be conducted on the provision of choice within personalized learning environments to further investigate the complexities, challenges, and opportunities associated with this practice" (Netcoh, 2017b, p. 391). This is what will set this study apart from previous studies. The 
findings from my study may help schools and teachers embarking on a similar change process to engage the reflections of the student's experience in the design and implementation process in order to align practice with outcome goals. My study seeks to explore student perspectives and put students' voices at the forefront.

According to the process model of curriculum development, the purpose of education should not be to fill students with objective knowledge, but to develop students' abilities to process information in ways that enhance understanding (Stenhouse, 1985). Educators must challenge themselves and archaic educational policies to redefine and reimagine the student experience. Consequently, professional practice in education must adapt to ever-changing situations. The practitioner is therefore well suited to generate his or her own expert knowledge.

\section{Theoretical Underpinnings and the Selection of Methodology}

Social constructivism serves as the underlying epistemology and interpretive framework for this study of the implementation of personalized learning. Piaget and Vygotsky were early proponents of this theory. Constructivism evolved because of the dissatisfaction with the instructional practices of rote memorization, regurgitation of facts, and the division of knowledge into different subjects (Dixon-Kraus, 1996). These methods resulted in learners who were not necessarily able to apply what they had learned to real life situations and scenarios (Senge, 2000). Teachers taught it, but the learning was not transferrable. Piaget described meaning making as a process of attaining equilibrium through assimilation and accommodation. In contrast, Vygotsky emphasized the effects of social interaction and focused on dialogue. Social constructivism thus embraces a dynamic interaction between and among teachers, learners and tasks, where learners can create their own understanding because of their interaction with others 
(Sternberg \& Williams, 1998). The learning process requires that the learner actively participate in creative activities, self-organization and the ability to link new information with schema to create connections. Fostering students' abilities to develop an understanding of concepts by building on existing knowledge, through inquiry teaching methods that are relevant and meaningful, is critical to increase student engagement. Bruner (1973) was an early proponent of discovery-based or inquiry-based learning. Students interact with the world by exploring and manipulating objects, as well as by wrestling with questions. Zone of proximal development (ZPD) is another component of the social constructivist theory that aligns with personalized learning (Sternberg \& Williams, 1998). This refers to the zone in which learning can most effectively take place, as it falls between what a student can do independently and new material used to challenge them. Reeves, Herrington, and Oliver (2002) highlight the importance of authentic educational activities embedded within online learning to the mix of more recent applications of constructivist theory. Woo and Reeves (2007) conclude that meaningful interaction should include responding, negotiating internally and socially, arguing against points, adding to evolving ideas, and offering alternative perspectives with one another while solving some authentic tasks.

Social constructivism, often described as interpretivism, is a paradigm or holistic view, (Denzin \& Lincoln 2011). Researchers utilizing this philosophy look for the complexity of views rather than narrow meanings (Creswell, 2018). In this study, I am seeking to understand the viewpoints and perceptions of students and their experience with personalized learning. It is my goal to listen to their individual responses to reveal patterns and interpret the complexity of their views. It is not about trying to solve a problem, but to understand how students feel about personalized learning and why. How does the pedagogy of personalized learning foster their 
growth and development as a learner constructing meaning of the world around them? The research questions and interview questions are broad and general so participants can construct meaning of the situation and the researcher can interpret the meanings the students have about personalized learning (Brown, Sorrell, McClaren, \& Creswell, 2006).

Grounded theory serves as a supporting framework that is foundational to this research study. The underpinning of grounded theory is that the collection of data and its analysis are concurrent. Because grounded theory methods study processes, these methods enable researchers to study the development, maintenance, and change of individual and interpersonal processes. It is a convergence of positivist methods and interpretive methods, both of which are found in the constructivist epistemology. Interpretive methods attempt to describe, explain, and understand the lived experiences of a group of people. The researcher seeks to learn how they construct their experience through their actions, intentions, beliefs, and feelings (Charmaz, 1996). In this case, the emergent themes and patterns that evolve during the data collection and analysis help to shape and lead the direction of the research.

Within the Junior/Senior High School that serves as the context of this qualitative case study are approximately 500 students. A constructivist epistemology and grounded theory approach supported the goal of this research study, which was to explore the perspectives and realities of students who experience personalized learning. I analyzed implementation of instructional practices that actively engage the students in the learning process, whereby they have the agency and voice to determine the pace and path that meets their individual learning needs with the support of mentors and teachers. 


\section{Definitions of Terms}

I used the following terms in the context of this study:

Agency: student voice and choice on level of standards/lesson and some control over how they learn (Patrick, Kennedy, \& Powell, 2013).

Blended Learning: is a combination of face-to-face learning experiences and online learning platforms, content, and tools for personalizing instruction (Patrick, Kennedy, \& Powell, 2013).

Competency-based learning: enables students to progress based on mastery rather than seat time; the competencies include specific, transferable, and measurable learning objectives; assess students in meaningful ways that ask students to apply knowledge and skills; and students receive specific targeted feedback on their progress across a continuum (Sturgis \& Casey, 2018).

Personalized Learning: is an instructional strategy that takes a holistic view of the individual, skill levels, interests, strengths and challenges, and prior knowledge. The learner understands how they learn and is motivated to own and drive their learning (Bray, 2015)

Student Voice and Choice: the foundations of a democratic classroom wherein the deep structures and widely held assumptions that learning equals the transmission of information from the holders of the knowledge (the teachers) to the empty vessels (students) no longer exist (Morrison, 2008). The development of a collaborative partnership between the teacher and the learner and among the learners (Biddulph, 2011).

\section{Organization of the Study}

I organized my study as follows: Chapter 1 includes the introduction, purpose, statement of research questions, rationale for the study, scope of the study, definition of terms, methods, data sources, and organizational summary of this study. Chapter 2 begins with a comprehensive 
review of the relevant literature. Chapter 3 provides an in-depth description of the qualitative case study methodology used to collect and analyze the data. Chapter 4 presents the findings of my study. Finally, Chapter 5 summarizes the findings of my study, and offers implications for policy, practice, and future research. 


\section{CHAPTER 2: LITERATURE REVIEW}

In this study, I explored student perceptions of personalized learning and their overall student experience. I sought to understand how student perceptions of their role in their own learning experiences have changed (if at all) because of the personalized learning initiative. Additionally, I examined how student perceptions of teachers and their fellow classmates influence their learning experiences. There are four research questions guiding this study with the first serving as an overarching driving question and the subsequent three delving into the impact on the student experience.

RQ 1: What are student perceptions of personalized learning and their overall student experience?

RQ 2: How have student perceptions of their role in their own learning experiences changed because of the personalized learning initiative?

RQ 3: How did student perceptions of the role of the teacher in their own learning experiences change because of the personalized learning initiative?

RQ 4: How did student perceptions of the role of their classmates in their own learning experiences change because of the personalized learning initiative?

In this chapter, I provide a comprehensive review of the relevant literature in order to provide some historical context of the need for and development of personalized learning as an instructional strategy. I begin the literature review with a brief historical primer on the U.S. educational system. I then review the extant literature on personalized learning, including the variation in definitions and its association with student outcomes. I then focus on the extant research that explores student perceptions and student voice. The chapter ends with a summary that captures the predominant themes of the extant research in terms of finding and methods used 
to arrive at these findings. Most notably, I end this summary with a clear warrant from the research literature, justifying the need for this study.

\section{A Brief Historical Primer of the U.S. Educational System}

Very little has changed in our education system over the course of the last one hundred years; however, during that same time frame we have experienced a plethora of changes in the world around us. We have transitioned to a global society and innovations in technology have led the way. Originally, the U.S. system of public education sought to prepare students for a life of repetitive, industrialized work. Over time, the number of manual and routine jobs has steadily declined within the United States in favor of more complex, non-routine forms of employment; jobs that required effective social and emotional skills (Laughlin, 2017). In addition, our education system seeks to educate the masses (Trow, 1999). The first outcome of this system is to impart knowledge to children to ensure that they can become productive members of society. Another outcome of this system is the sorting of students for jobs in the workforce.

Across urban, suburban, and rural settings, researchers note a common problem of practice: the lack of students engaging in purposeful and active learning. Taylor and Parsons (2011) found that engaging students in the learning process increases their attention and focus, motivates them to practice higher-level critical thinking skills and promotes meaningful learning experiences. Instructors who adopt a student-centered approach to instruction increase opportunities for student engagement, which then helps everyone more successfully, achieve the learning objectives. Today's workforce requires students to have soft skills and competencies to be able to think critically to problem solve, have resiliency, be innovative and creative, communicate and collaborate effectively, and lead for change. The need for these post- 
secondary skills require educators to think differently about the practices utilized to prepare our students for jobs of the future. The massive shifts of technology and globalization that disrupt current trends in the workplace have already begun. In many industries and countries, some of the most in-demand jobs were not in existence five or 10 years ago — and the pace of change will only accelerate. According to the World Economic Forum in its 2016 report, $65 \%$ of children entering primary school today will ultimately end up working in completely new job types that do not yet exist.

Instructional practices and the structure of many schools across the United States have changed very little over the last century. Classroom instruction is still mostly led by teachers who tell students what to know, how to know it, what to think about it, and how to regurgitate it on a test. The needs of the workforce have changed dramatically in the same period. There exists a gap between the outcomes of schools and the needs of the $21^{\text {st }}$ century workforce (World Economic Forum, 2016). One proposed way to change that experience is through the pedagogy of personalized learning. The purpose of personalized learning is to empower students and to offer a student-centered environment designed to meet with varying needs of today's learners.

According to Department of Commerce, National Economic Council (2012), among high school graduates who attend college, $20 \%$ have the need to take remedial courses and students with this requirement are less likely to graduate with a bachelor's degree. The report also identifies an inadequate K-12 education as a cause to the number of students in the US obtaining a college degree to slip compared to its international counterparts. This speaks to the need for a redesign of our K-12 programming. Our students are coming to school with many barriers to learning in their invisible backpack, and according to The SHARE Team (2020), if we do not change the way we do business, we will continue to lag behind in this world of innovation. 
The New Teacher Project (TNTP) has been a voice for changing the educational outcomes for students and schools across the US since 1997. TNTP conducted a study, (The New Teacher Network, 2018) digging into the results that our current K-12 system of schooling is producing. It found that while more students are going to college than ever before, fewer are succeeding once they get there with over $40 \%$ having to take remedial courses once enrolled. One of the most astonishing findings indicated that in the nearly 1,000 lessons observed, across five diverse K-12 school systems, students were working on activities related to class 88 percent of the time. They met the demands of their assignments 71 percent of the time, and more than half brought home A's and B's. Yet students only demonstrated mastery of grade-level standards on their assignments, a benchmark for being on track for the lives most of them want as adults, 17 percent of the time. This disparity is magnified if the student belongs to a minority group or has a disability. This is yet another indication that the current system is not meeting the needs of all students. The results of the study support the need to include the identified four components required to be present in order to increase student success. The components include: consistent opportunities to work on grade level assignments, strong instruction where the students do the heavy lifting and most of the thinking, deep engagement in what they are learning, and teachers who hold high expectations and believe that students can meet grade level standards (The New Teacher Network, 2018).

Sturgis and Casey (2018) identified ten flaws in the traditional U.S. educational system. First, the traditional system is focused on a narrow set of academic outcomes emphasizing academic skills, memorization and comprehension of content. Second, the traditional system is built on a fixed mindset - the notion that people's abilities "are carved in stone". Third, the system relies upon a bureaucratic, hierarchical system that perpetuates traditional roles, cultural 
norms and power dynamics that values compliance and does not support inclusivity and cultural responsiveness. Fourth, the traditional system allows high variability in how educators determine proficiency in traditional settings. Fifth, the traditional system articulates opaque learning objectives and performance expectations with limited information for students about the learning cycle. Sixth, the traditional system uses academic grading practices that can often send mixed messages and misleading signals about what students know by reflecting a mix of factors, including behavior, assignment completion and getting a passing grade on tests, not student learning. Seventh, the traditional system is time-based moving all students through the same content and courses at the same pace. Eighth, the traditional system is organized to efficiently cover the curriculum based on age and depends on extrinsic motivation. Ninth, the traditional system targets supports to students when their academic or behavioral needs are identified as significantly above or below the norm (i.e. special education, gifted). Finally, the traditional system emphasizes assessment for summative purposes to verify what students know. The design of the system treats all students the same, but is that equitable. On the other side, the instructional pedagogy of personalized learning addresses each of these flaws.

While accountability systems have exposed the inequities in education, they have done little to reduce inequitable outcomes for marginalized populations. The traditional system, built on a narrow set of outcomes that emphasize academic skills and not the development of the whole child, is simply not set up to achieve the outcomes set out for it. In this way, the fixed mindset that ranks and sorts foundationally built the traditional system, instead of the core belief that all students can achieve at high levels with the right supports. It is also set up on Carnegie units that require seat time and does not take into account that all students learn differently and 
have different relative strengths. It is a one-size-fits-all system and when you look deeply at the nationwide data, it simply does not add up to success for our students.

\section{The Changing Role of the Teacher and the Student}

Prior to the advent of state standards, assessment, and accountability systems, teachers historically held substantial power and control over the curriculum and its delivery in their classrooms. Arnot and Reay (2007) examined the 'Young People's' Geographies' (YPG) finding that student opportunity for voice in school expanded beyond student council, clubs and sports. The curriculum embedded student voice and choice. Biddulph (2011) explores the outcomes, which sought to establish dialogue between students, geography teachers, academic geographers, and teacher educators to inform the curriculum. In addition, the study explored ways in which students and teachers can collaboratively use the lived experiences of students to embed within the curriculum. Lastly, the researchers sought to develop pedagogies that enable students to use those experiences to build understanding, thus shifting the heavy lifting toward the students. One key finding was the importance of the role the teacher plays in serving as a mentor and providing opportunities for students to build efficacy. The study also acknowledged the extent of the shift required in the system in order for this to facilitate long-term changes to the educational system.

Covey (2014) states that student empowerment starts from a powerful premise - that every child possesses unique strengths and has the ability to lead. Analysis of triangulated data to determine the specific strengths and weaknesses of students in order to uncover their individual entry point for accessing curriculum fosters empowerment. This level of customization enables the teacher to target instruction based on student need, whether that is to scaffold instruction or extend it. 
Scholars also utilized quantitative methodologies to gain greater understanding about personalized learning and its association with student achievement. Wolters and Pintrich (1998), using a within-subject correlational design, examined student motivation through the lens of three identified motivational factors: self-efficacy, task value, and level of task anxiety. The research delved into the relationship between a student's level of self-regulation and motivation. Findings suggest that students who are able to self-regulate are able to control their actions to attain learning goals that they define for themselves. In other words, they can talk the talk of the learning process as well as walk the walk.

Furtak and Kunter (2012) suggest the role of the learner and the role of the teacher have shifted. To determine the effect of cognitive and procedural autonomy-supportive teaching, the study design included $2 \times 2$ repeated measures factorial experimental design with an appended baseline test/retest group. There were four treatment conditions built within the study that combined two levels of procedural autonomy (hands-off activities vs. hands-on activities) and cognitive autonomy (controlling vs. supportive) teaching approaches. In the traditional classroom, the teacher holds all of the responsibility for authority and delivery of instruction. In the $21^{\text {" }}$ Century classroom, however, the teacher is less of an absolute authority and serves more as a guide who provides scaffolding for students. These learners have more autonomy, are expected to be more actively engaged, and are now more responsible for their own learning process. Although autonomy-supportive teaching links with increased student performance, this contention is yet to be explored in an experimental study. However, factors for further consideration point to perceptions of the students and their teachers shift after implementation.

Waldrip et al. (2014) examined the outcomes of students in Bendigo, Victoria who participated in personalized learning that: differentiates instruction through development of 
personalized learning plans, utilizes teaching strategies that promote independence and selfmotivation, and develops students' social and emotional well-being. Using a within-subject correlational design, the study assessed mean level differences in students' task value, selfefficacy, test anxiety, cognitive strategy use, regulatory strategy use, and classroom academic performance by gender and across the subject areas of mathematics, social studies, and English. In addition, assessments using multivariate regressions measured the relationships among motivational, strategy use, and performance measures. These scholars field-tested a set of 66 questions to evaluate student perceptions regarding personalized learning. Students rated each item on a 5-point Likert scale. The questions linked intentionally to the dimensions and variables involved with implementation of a personalized learning plan. This questionnaire may provide a picture of the impact of personalized learning on outcome variables. Because of the intentional development of the tool and the design approach employed, the resulting reliability and validity of the results may provide intuition regarding the impact on students. This study points to the value of obtaining student input regarding their perceptions of their experience in a personalized learning classroom.

\section{Student Engagement and the Role of Student Agency}

As previously stated, there are many dimensions surrounding the educational practice of personalized learning: student agency, the role of the learner, and student voice all play an integral role engaging the learner. The U.S. Department of Education defines agency as learning through student-centered activities that are meaningful and relevant to student's lives (National Forum on Education Statistics, 2019). An empirical study of personalized learning through a qualitative exploration has pointed out understanding the importance of student agency. Deed et al. (2014) investigated how teachers and students characterize agency with the implementation of 
personalized learning. The study found that a balance between allowing students to self-manage their own developing adaptive agency and the co-regulation of this development by educators is crucial for student success. A recent qualitative study by Netcoh (2017b), explored how students and teachers perceive choice as a motivator in a personalized classroom experience. A key finding from this study was that the amount of choice and openness of choice shapes the kind of relationships that teachers have with their students.

Martin defined agency as "the capability of individual human beings to make choices and act on these choices in a way that makes a difference in their lives" (2004, p. 135). According to Lindgren and McDaniel (2012), agency and choice is generally elicited through interface and environment design. This is a constructivist theory in that learning and knowledge are built through the processes of one's actions within their environment, and in this case, that is the classroom. Agency then, is giving students the power and control to self-regulate and become drivers of their learning.

The teacher and the classroom culture are keys to the success of implementation of personalized learning (Redding, 2013). The teacher's ability to use his or her influence to further learning depends on pedagogy, but more importantly from the personal relationship with each student and the class as a whole. Self-efficacy influences motivation, learning, and achievement. If a student believes that the learning task is of value and that it is in fact attainable, then they will persevere. This expectancy theory adds the level of opportunity cost to the motivation equation. The work of Carol Dweck (2007) on growth mindset aligns with this philosophy. She goes even further to say the mindset of the teacher about the student's potential has a tremendous impact on outcomes. 
Learning is something that should actively involve students, not a passive act done to students (Casey \& Sturgis, 2018). When students have agency, they can find purpose in learning and are able to persevere through challenges. This autonomy in learning promotes motivation, as students are empowered to take ownership in the learning process. Educators need to promote agency through coaching, provide clear measurable outcomes, and offer targeted specific feedback that guides the student on their learning journey. This shift from compliance to empowerment is transformative for students and teachers alike. Agency is not simply about choice, as choice is only one practice that supports building agency.

Student agency is one component of personalized learning that empowers students to exert their voice and take a more active role in the learning process. That alone, however, does not constitute personalizing learning. Personalized learning also encompasses changing the manner of assessing students' proficiency or mastery.

\section{Competency Based Learning}

Competency based learning does not equal personalized learning; nor is the reverse true. They are complements to each other and support student-centered learning. Sturgis and Casey (2018) developed a five-part working definition in partnership with the field at the Competencybased Education Summit hosted by iNACOL and Council of Chief State School Officers (CCSSO): 1. Students advance upon demonstrated mastery. 2. Competencies include explicit, measurable, transferable learning objectives that empower students. 3. Assessment is meaningful and a positive learning experience for students. 4. Students receive rapid, differentiated support based on their individual learning needs. 5. Learning outcomes emphasize competencies that include application and creation of knowledge along with the development of important skills and dispositions. 
Competency-based education (CBE), referred to as mastery-based, proficiency-based or performance-based education, ensures all students develop the success skills they will need for college, career and life. This results in a paradigm shift from the time-centered approach to education that is present in traditional schools. In the past, and still in many schools today, learning is segmented into time frames; whether that be a period bell to transition to the next class, the length of a unit with an exam at the end, a grading period, or a school year, time is the factor related to completion of learning. With competency-based education, mastery of skills defines where a student falls on the continuum of learning. In a proficiency system, failure or poor performance may be part of the student's learning curve, but it is not an outcome (Casey \& Sturgis 2018).

Competency education operates on the premise that learning operates on a continuum and teachers need to meet students where they are academically, socially, and emotionally in order to move them forward. This provides all students with an entry point to access grade appropriate content and standards. In this way, competency education is an equalizer for all students. The student population (Casey \& Sturgis, 2018) informs all pedagogy, student supports and resource allocation. This is where personalized learning and competency-based education coexist. Competency-based education assumes that we will meet students where they are and personalized learning optimizes instructional strategies to support students on their learning journey. Personalized learning helps to build the mindset and habits of success students need to become self-directed learners and engage in productive struggle (Casey \& Sturgis, 2018).

In a CBE setting, learning targets (competencies) are explicitly communicated with students and based on a rigorous set of expectations aliRgned with college and career readiness outcomes. Students demonstrate mastery of the standards in order to progress and advance 
academically. Decreasing emphasis on seat time results in increased flexibility for students regarding when and where they complete their work and greater opportunities to earn credit through activities, projects, online coursework, and internships completed outside of the traditional school setting and schedule (Haynes et al., 2016). Assessment for learning as opposed to assessment of learning is also a focus with CBE, along with the importance of feedback to provide students the support they need to master the competencies. Assessment, unlike in the traditional setting, takes on many formats instead of all students being assessed in the same manner and at the same time. In fact, in many instances, technology is a tool utilized to customize instruction and track student proficiency (Haynes, et al., 2016).

Educators and policy makers continue to struggle with the challenge of matching curriculum and pedagogy with the needs for skills and competencies by employers. Postsecondary institutions are grappling with a similar challenge to better align outcomes with industry needs (Hagan-Short \& Addison, 2019). The solution was to develop a credential in CBE format offering personalized progression, while maintaining individual courses that were transferable. The concept of an adaptive delivery system allowed for individualization while maintaining quality control. The community colleges engaged in this study continue to work through the process of developing a more comprehensive program. This information supports the need for change in the field of K-12 education in order to prepare students for post-secondary education and/or the work force directly.

\section{Blended Learning/Technology}

Students today are different in many respects, in part due to the global society in which we live and the technological advances of the $21^{\text {st }}$ century. Today's students are digital natives (a person born or brought up during the age of digital technology), whereas those that teach them 
are, for the most part, digital immigrants (typically born prior to the 1980s, and were not raised in a digital environment). This has changed the way students take in and process information. Technology has rewired the brains of our students (Jukes, 2007). We used to live in a low-tech world with face-to-face communication and our imaginations developed images as opposed to on a screen. According to Jukes (2007), 82\% of American children play video games on a regular basis - an average of 8.2 hours a week. As a result, over $70 \%$ of the dollars spent by children and teenagers on toys are for electronic games. These digital natives learn differently and the traditional pedagogy may not be enough to keep them engaged and motivated to learn. Digital natives have become very sophisticated thinkers, which many digital immigrants find hard to believe. There is an emerging world where critical thinking, problem solving, and a deep level of information fluency is increasingly more important than content recall by itself (Pink, 2005).

There has been some negative media attention recently with regard to personalized learning and the use of technology. The alliance between education policymakers and billionaire technologists could undermine the role of teachers and the public sphere- has only become more relevant (Kim, 2019). While the premise of personalized learning is to create a school and classroom environment that provides open, flexible teaching strategies, increases students' agency over their own learning, and addresses the needs of the whole child, it is not solely online learning (Greene, 2019). Parents and community members have expressed concerns that teachers are not teaching and that computers are replacing human interaction. Personalized learning has become synonymous with the use of technology and that is a huge misconception. The fact is, that technology is a tool to support personalization, but is not personalization in and of itself (Netcoh, 2017a). 
Blended learning is defined as "any time a student learns, at least in part, at a supervised brick-and-mortar location away from home and, at least in part, through online delivery with some element of student control over time, place, path, and/or pace. The modalities along each student's learning path within a course or subject are connected to provide an integrated learning experience" (Christensen, Horn, \& Staker, 2013, p. 7). The four models within blended learning: rotation, flex, ala-carte, and the enriched virtual model offer choices and flexibility based on resources and context. In the rotation model, students rotate on a fixed schedule or at the teacher's discretion between learning modalities, at least one of which is online learning. In the flex model, students move on an individually customized, fluid schedule among learning modalities (of which, online learning is the backbone), and the teacher of record is on-site. The A La Carte model is one in which students take one or more courses entirely online with an online teacher of record and at the same time continue to have brick-and-mortar educational experiences. Finally, the enriched virtual model offers students a combination of attending faceto-face classes in the brick and mortar building, as well as learning remotely using online delivery of content and instruction. These models offer students greater flexibility and control over their learning and involves a shift in the instructional pedagogy to one that optimizes student learning. It enables resources and tools to drive the learning process. These tools also enable teachers to more effectively provide real-time feedback and use data at their fingertips to support student learning. This student-centered approach also provides opportunities for inclusion and access to grade appropriate content for ALL students. Technology can serve as a lever to support personalized learning.

Blended learning and the use of technology, particularly one-to-one initiatives are seen as disruptive innovations in education, when it is really a hybrid as it seeks to improve the 
instructional setting - not merely replace it - by using sustainable strategies (Christensen, Staker \& Horn, 2013). The Station Rotation, Lab Rotation, and Flipped Classroom models, as previously described, introduce a hybrid solution that marries the traditional classroom with online learning. Many critics however, view blended learning in its disruptive form as a replacement for the traditional brick and mortar structure. In some cases, opponents are seeking legislation or school board policies to make online learning go away.

\section{Personalized Learning Defined-Multiple Perspectives}

Personalized learning represents an approach to education that increases students' opportunities to drive their learning. Many educators surveyed by iNACOL understand how personalization can transform learning and describe it as a promising strategy to close achievement gaps, increase student engagement, and prepare students, as they become selfdirected, lifelong learners by meeting students' individual needs (Patrick, Kennedy, \& Powell, 2013). While no single definition of personalized learning exists, the many definitions from leading experts share common general principles that include student voice and choice, customization to each student's strengths and needs, student agency, and flexibility of instruction.

Many definitions of personalized learning exist which conflate it with differentiated learning; however, they are not the same. Patrick, Kennedy, and Powell (2013) offered one definition that states that personalized learning is tailoring learning for each student's strengths,

needs and interests - including enabling student voice and choice in what, how, when and where they learn — to provide flexibility and supports to ensure mastery of the highest standards possible. This definition clearly sets it apart from differentiation as it outlines that personalized learning is student centered and empowers the student to take ownership. It also offers that 
differentiation is actually a component of personalized learning; along with student agency, ondemand instructional supports, flexible pacing, individual student profiles, frequent feedback, opportunities for deeper learning and problem solving, standards based, flexibility in location, performance based, and project based. Traditional education offers a more one-size-fits all feel with students navigating through the same curriculum and activities at the same level and pace.

Sota (2016) expands on the idea offered above to include the student being an active agent in the decision-making process. She defines instruction as being a combination of instructional episodes that include types and features of learning activities, where the learner engages in these activities, the pace of instruction, the amount of instruction and practice, the instructional goals or objectives, and the standards and tools of measurement to achieve those goals and objectives. In the traditional classroom, the teacher controls all of these fixed episodes. On the other end of the spectrum, these are completely self-directed. It is important, according to Sota (2016), that in order to maximize the positive effects of learner choice, that teachers and students co-design instruction where the teacher coaches the student and fosters the growth of self-regulating skills.

Johnson (2004) offers a definition that targets instructional implications requiring a change in focus of assessment for learning instead assessment of learning to identify individual strengths and weaknesses. Building the competence and confidence of students through individualized learning, with every student enjoying some level of curricular choice. Personalized learning provides students with opportunities for in-depth, intensive teaching and learning, combined with flexible deployment of support staff, and finally the community, local institutions and social services supporting schools to drive forward progress in the classroom. The underlying premise is that teachers must take into account where a student is on the learning 
continuum as well as where their learning preferences lie in order to develop opportunities that will increase success for that student. He also posits that in a world of increasing geographical mobility and cultural mixing, the work of schools in producing cohesion within mixed communities becomes ever more important.

The basic premise of personalized learning is that each student is unique and learns in different ways. Nandigam, Tirumala, and Baghaei (2014) offer that personalized learning may stem from Howard Gardner's multiple intelligences and concur with the belief of many that it is consistent with constructivist learning theories. Their definition proposes that this environment provides all available resources for learning, including teachers, parents, peers, technology, time, and learning spaces, and flexibly to meet individual student learning needs. They also offer that there exists a continuum on which implementation occurs.

Implementation of personalized learning looks different in different places and there are many misconceptions about the purpose and goals of moving in the direction of this innovative instructional practice. Beliefs about the methods and what students experience in this type of learning environment vary greatly. For example, some schools adhere to a prescribed formula, and others allow the initiative to grow organically (Wolf, 2010). The symposium identified five essential elements of personalized learning (Wolf, 2010). Flexible learning extends beyond the traditional environment to include online learning, blended learning, opportunities in the community, and instruction offered by a variety of experts. The role of the teacher is redefined and broadened beyond just deliverer of instruction, but includes facilitator of learning and mentor. Project-based and authentic learning opportunities can help increase the relevance of learning and improve students' ability to apply knowledge and use critical thinking skills. A student driven learning path is synonymous with personalized learning, and provides 
opportunities that consider interests, abilities, and a whole child approach. It requires a shift from all students doing the same work at the same time to an approach wherein the student accesses standards at a time and manner, which meets their needs.

\section{Literature Review Summary}

The literature review revealed the need for transformation in schools as the workforce has demonstrated a need for employees of the future to hold a different skillset than those of the past. The landscape of jobs is ever changing and students in the current K-12 system are preparing for jobs that may not yet exist. There is a need for students to exit secondary education with a mastery of competencies that will carry them into a global economy redefined through technology and innovation.

Personalized learning is not an easy concept to define, and implementation in a multitude of ways is evident from the research reviewed. Across definitions, some patterns and themes emerge. This approach is more learner centered compared to traditional approaches to schooling. It is clearly not a one size fits all model, as students have voice and choice in the process and product empowering students to take ownership over their learning. In this environment there is greater flexibility in pace and place, as opposed to the more structured Carnegie units that place emphasis on seat time. To that same point, mastery of competencies is the focus of progression. The basic premise of personalized learning is that each student is unique and learns in different ways.

There are many factors to consider with the implementation of this innovative pedagogy. The role of the student and the teacher shift upon implementation. Instead of the teacher delivering the same instruction to a full class in a single event, the teacher is able to customize learning to meet the individual needs of the learner. Customization creates opportunities to 
personalize content, path, pace, and/or product depending upon the needs of the student.

Students are also more empowered to take control and ownership of their learning through their active agency and input through voice and choice.

Another shift is the focus on mastery learning as opposed to satisfactory completion of coursework within a specified period. A competency based education system expects students to demonstrate mastery of the standards in order to progress and advance academically. It relies on the guiding premise of meeting students where they are academically, socially, emotionally in order to move them forward. This shift further fosters a student-centered learning environment. It is no longer teacher-centered, but about student mastery of learning.

The last major shift is the method of instructional delivery with the implementation of personalized learning. In the traditional system, the teacher holds the power and is in complete control of delivery of instruction. Personalized learning delivers instruction through a blended model. This incorporates face-to-face time paired with digital delivery of instruction. It is through technology that teachers are able to differentiate and individualize to meet students where they are like never before. There are many misconceptions that the technology is doing the teaching, but that is not the case. Students are immersed in the use of resources and tools through technology that allow them to make meaning, infer, discover, and inquire about content related topics with the guidance and support of their classroom teacher.

In this literature review, I focused on the idea that changes in the U.S. workforce require an educational transformation. One of the ways to transform our educational system is to implement innovative approaches that empower students to take a more active role in the learning process; thereby owning their learning. The literature provides perspectives to understand personalized learning and other instructional pedagogy associated with this 
innovative instructional practice. The findings of this study may help schools embarking in a similar change process to engage the reflections of the student's experience in the design and implementation process in order to align practice with outcome goals.

Chapter 3 outlines the research methodology and design, including the purpose, design, data collection and data analysis procedures. The chapter also includes a discussion of the study's limitations, credibility, and ethical issues. 


\section{CHAPTER 3: METHODOLOGY}

In this study, I explored student perceptions of personalized learning and their overall student experience. I sought to understand how student perceptions of their role in their own learning experiences have changed (if at all) because of the personalized learning initiative. Additionally, I examined how student perceptions of teachers and their fellow classmates in their learning experiences. There are four research questions guiding this study with the first serving as an overarching driving question and the subsequent three delving into the impact on the student experience.

RQ 1: What are student perceptions of personalized learning and their overall student experience?

RQ 2: How have student perceptions of their role in their own learning experiences changed because of the personalized learning initiative?

RQ 3: How did student perceptions of the role of the teacher in their own learning experiences change because of the personalized learning initiative?

RQ 4: How did student perceptions of the role of their classmates in their own learning experiences change because of the personalized learning initiative?

The purpose of Chapter 3 is to justify and describe the research methodology for this qualitative case study. In particular, this chapter will delineate the research process that I used to answer the aforementioned research questions of student experiences with personalized learning. In terms of structure, I organized Chapter 3 as follows. First, I began by stating and rationalizing the selection of my research design (a qualitative case study) and the limitations of this analytical strategy. I then discussed context of the qualitative case study. I then discussed the various data sources and the corresponding data collection procedures that I used to obtain them. Given that 
secondary education students served as the informants for my study, I gave careful attention to the ethical considerations in collecting data from a protected class (minors). I also discussed the process by which I analyzed the data collected. As a scholar-practitioner undertaking research in the school district in which I am employed, I discussed the process by which I explored my positionality and relationship with the topic, students, school, and district in which the study will take place. Lastly, I discussed the strategies by which I will ensure credibility, transferability, dependability, and confirmability of the finding I generated.

\section{Research Methods and Design-Qualitative Case Study}

Creswell (2018) explains that the process of research flows from philosophical assumptions, to interpretive lens, and on to the procedures involved in studying social or human problems. The collection of data in the natural setting sensitive to the people and place under study is inductive to establish patterns and themes. This qualitative case study utilized a bound single case holistic research design (See Figure 1). Yin (2018) identified a focus on "how" and "why" questions tend to lean more toward explanatory research in nature and leads to the use of a case study. If the purpose of the study is to gain an understanding as to why something occurred, you would draw upon documentary information in addition to conducting interviews, and a case study approach would be appropriate. A case study entails direct observation of events under study and includes interviews with those involved currently or previously in the event. The underlying premise is that it tries to illuminate the why behind a decision(s), the implementation process, and results, which directly correlates to the purpose of my study. The interpretive lens through which I sought to understand the phenomena in my study is from a relativist point of view. The relativist aligns with the constructivist approach in an effort to capture multiple perspectives and their illumination of the topic of study. 
In this study, I intended to capture the perceptions of a cross-section of students to understand how the implementation of personalized learning has changed or not changed their student experience. I embarked on an exploration of the operational process of implementing personalized learning and the ensuing perceptions of the students involved. I was not wondering why or how it occurred; I was more interested in the line of inquiry of what happened during this potentially transformational process.

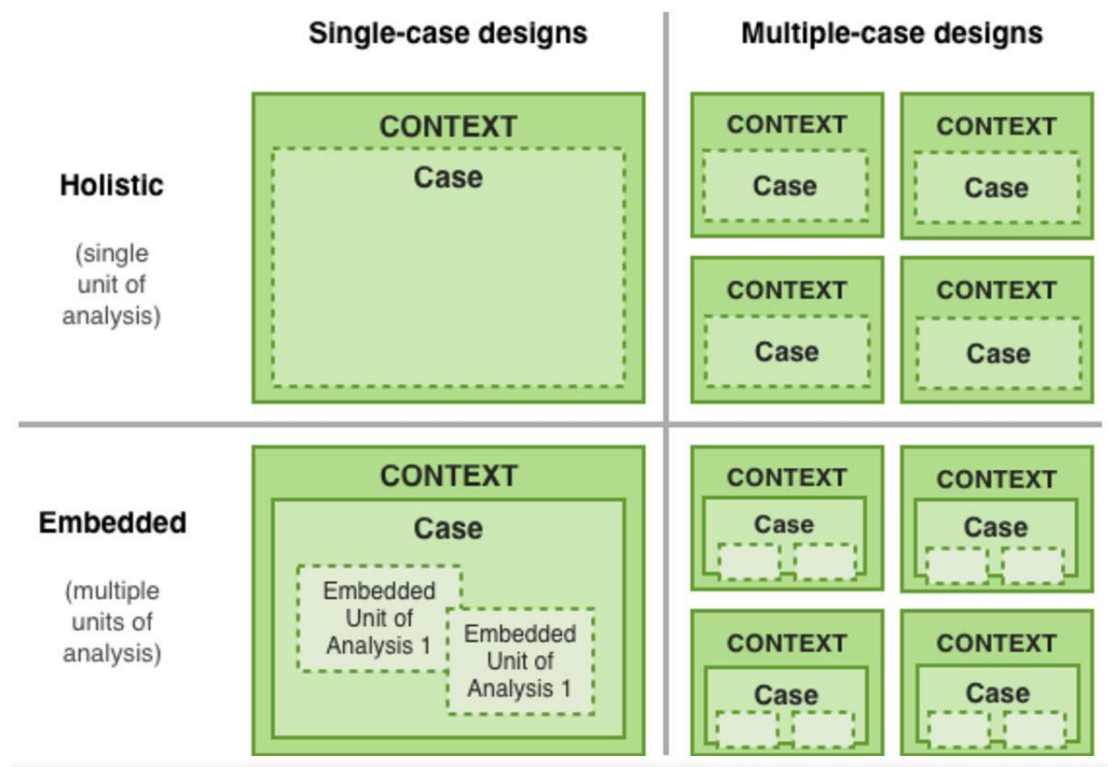

Figure 1. Yin's (2018) Typology of Case Study Designs

\section{Strengths and Limitations of Qualitative Case Studies}

While case study research is a distinctive mode of social science inquiry, there has been confusion conflating case studies with "fieldwork" (Yin, 2018). There is a distinctive need for case studies to gain understanding of complex social phenomena, as they enable the researcher to retain a holistic and real-world perspective. There are many academic disciplines and practicing professions that do not subscribe to the idea that case study work is only a preliminary mode used in other research methodology (Yin, 2018). Some in the field of research have expressed 
concerns regarding the level of rigor due to evidence of poor quality case study research that exists (Creswell, 2018).

Case study research is a valuable method when a researcher is developing an in-depth description and analysis of a case. The strength of a case study lies within the ability to provide an in-depth understanding of a case using multiple sources of data, such as interviews, observations, documents, and artifacts (Creswell, 2018).

\section{Context of the Study}

In this study, I undertook a qualitative case study in a rural Kentucky secondary school that began implementing personalized learning in 2017. School report card data and past performance on state student assessments suggest that the current system was not meeting the needs of Trimble County School District (TCSD) students. Although Trimble County Junior/Senior High School emerged from PLA (persistently low-performing) accountability status at the beginning of the 2016-2017 school year and while both graduation rates and overall test scores have improved, students still underperform in the state's reading, math, and overall college readiness measures. The middle school and high school merged physically at that point and officially closed at the end of the 2017-2018 school year to re-open as a consolidated Trimble County Junior/Senior High School for the 2018-2019 school year due to historic declining enrollment. During the 2017-2018 accountability cycle, the state department of education identified the middle school as a TSI (targeted support and improvement) school due to poor standardized test scores of students receiving free/reduced lunch. TCSD has experienced a continuous declining enrollment (See Table 1), and has limited diversity among its student racial demographics (See Table 2). 
In terms of school demographics and program enrollments, (See Tables 1 and 2).

Accountability outcomes since exiting TSI status have been stagnant (See Tables 3, 4 and 5).

As a result, TCSD leaders at the school- and district-level engaged in a collaborative process to redesign the way school structures and delivers the curriculum and instruction with the goal to reimagine and personalize learning (student agency with: pace, path, place, and voice) for students and to support parents as TCSD prepares learners for radically different futures.

Table 1. Enrollment Trends, Trimble County School District and Trimble County Junior/Senior High School, 2016-2017 to 2020-2021

\begin{tabular}{lcccccc}
\hline School & $\begin{array}{c}\text { Actual 2016- } \\
17\end{array}$ & $\begin{array}{c}\text { Actual } \\
2017-18\end{array}$ & $\begin{array}{c}\text { Actual } \\
2018-19\end{array}$ & $\begin{array}{c}\text { Projected } \\
2020-21\end{array}$ & Change & \% Change \\
\hline JR/SR & 585 & 567 & 553 & 530 & $(23)$ & $-4 \%$ \\
HS & & & & & & \\
\hline District & 1257 & 1185 & 1180 & 1114 & $(66)$ & $-5 \%$
\end{tabular}

Table 2. Demographics, Trimble County Junior/Senior High School (2018-2019)

\begin{tabular}{|l|r|r|}
\hline \multicolumn{1}{|c|}{ Demographic } & N & \% \\
\hline School \% White & 499 & 95 \\
\hline School \% African-American & 3 & .5 \\
\hline School \% Hispanic & 13 & 2 \\
\hline School \% Asian & 3 & .5 \\
\hline School \% Native American & 1 & .2 \\
\hline School \% Hawaiian/Pacific Islander & 2 & .3 \\
\hline School \% Multiracial & 5 & 1 \\
\hline School \% Male & 272 & 52 \\
\hline School \% Female & 254 & 48 \\
\hline School \% Free/Reduced Lunch & 292 & 55.5 \\
\hline School \% ELL & 5 & 1 \\
\hline School \% ECE & 46 & 9 \\
\hline School \% Gifted & 114 & 22 \\
\hline
\end{tabular}


Table 3. School Performance Indicators, 2016-2017

\begin{tabular}{rlrrrrr}
\hline $\begin{array}{c}\text { Grade } \\
\text { Levels }\end{array}$ & Content Area & Novice & Apprentice & Proficient & Distinguished & $\begin{array}{c}\text { Proficient/ } \\
\text { Distinguished }\end{array}$ \\
\hline \multirow{4}{*}{$7-8$} & Reading & 26.4 & 21.8 & 36.3 & 15.5 & 51.8 \\
& Mathematics & 30.6 & 42.5 & 20.2 & 6.7 & 26.9 \\
& Science & - & - & - & - & - \\
& Social Studies & 14 & 32.3 & 37.6 & 16.1 & 53.8 \\
& Writing & 15.1 & 40.9 & 34.4 & 9.7 & 44.1 \\
\hline \multirow{4}{*}{$9-12$} & Reading & 41.7 & 9.3 & 40.7 & 8.3 & 49.1 \\
& Mathematics & 31.8 & 35.3 & 27.1 & 5.9 & 32.9 \\
& Science & 34.7 & 45.3 & 20 & 0 & 20 \\
& Writing & 22.4 & 32.9 & 38.2 & 6.6 & 44.7 \\
\hline
\end{tabular}

Table 4. School Performance Indicators, 2017-2018

\begin{tabular}{|c|c|c|c|c|c|c|}
\hline $\begin{array}{l}\text { Grade } \\
\text { Levels }\end{array}$ & Content Area & Novice & Apprentice & Proficient & Distinguished & $\begin{array}{c}\text { Proficient/ } \\
\text { Distinguished }\end{array}$ \\
\hline \multirow{5}{*}{$7-8$} & Reading & 26.0 & 21.9 & 35.4 & 16.7 & 52.1 \\
\hline & Mathematics & 24.0 & 48.6 & 21.2 & 6.3 & 27.4 \\
\hline & Science & 18.0 & 62.0 & 18.0 & 2.0 & 20.0 \\
\hline & Social Studies & 16.7 & 30.2 & 44.8 & 8.3 & 53.1 \\
\hline & Writing & 12.5 & 49.0 & 33.3 & 5.2 & 38.5 \\
\hline \multirow{4}{*}{$9-12$} & Reading & 31.7 & 23.2 & 31.7 & 13.4 & 45.1 \\
\hline & Mathematics & 28.6 & 39.3 & 32.1 & 0.0 & 32.1 \\
\hline & Science & 28.0 & 52.4 & 18.3 & 1.2 & 19.5 \\
\hline & Writing & 18.1 & 36.1 & 36.1 & 9.6 & 45.8 \\
\hline
\end{tabular}

Table 5. School Performance Indicators, 2018-2019

\begin{tabular}{rlrrrrr}
\hline $\begin{array}{c}\text { Grade } \\
\text { Levels }\end{array}$ & Content Area & Novice & Apprentice & Proficient & Distinguished & $\begin{array}{c}\text { Proficient/ } \\
\text { Distinguished }\end{array}$ \\
\hline \multirow{4}{*}{$7-8$} & Reading & 25.3 & 22.1 & 35.8 & 16.8 & 52.6 \\
& Mathematics & 24.7 & 49.5 & 21.1 & 4.7 & 25.8 \\
& Science & 30.4 & 47.8 & 21.7 & 0 & 21.7 \\
& Social Studies & 12.2 & 44.9 & 35.7 & 7.1 & 42.9 \\
& Writing & 26.5 & 53.1 & 15.3 & 5.1 & 20.4 \\
\hline \multirow{4}{*}{$9-12$} & Reading & 30.3 & 23.7 & 34.2 & 11.8 & 46.1 \\
& Mathematics & 38.7 & 30.7 & 30.7 & 0 & 30.7 \\
& Science & 31.1 & 45.9 & 23 & 0 & 23 \\
& Writing & 18.9 & 47.3 & 27 & 6.8 & 33.8 \\
\hline
\end{tabular}


The district shares the same common goals of many other systems, such as increasing student achievement, closing gaps, and preparing students for college and career readiness (Ingle, Greenwell, \& Woods, In press), and therefore the findings may be useful to other districts exploring the potential implementation of personalized learning. I have selected this site, as it strategically embraced the instructional practice of personalized learning. Because this study focuses on the implementation phase, the school chosen is only in its third year of implementation and has gone through several iterations through a combination of internal staff reflection and external feedback from outside partners. While that has streamlined many procedures and processes, it has not revealed the level of student buy-in and voice regarding their perceptions of their experience and impact is yet to be determined. Students at the secondary school level struggle with engagement due to social emotional factors related to this age group. In response, the district selected personalized learning as a core instructional intervention.

Students in grades 7 through 12 are participating in a personalized learning model, of which competency based learning is foundational, through the Summit Learning Platform for all core content classes (English language arts, math, science, and history). Developed in 2004, the Summit Learning Platform offers schools and districts a customizable, standards-aligned curriculum for grades 4 through 12 in core subjects, including customizable hands-on projects, teaching and learning resources, and assessments (Summit Learning, n.d.). Summit components include self-paced, mastery learning of focus areas, performance based assessment through project based learning, and goal setting. The embedded student dashboard provides teachers the opportunity to offer specific real time feedback and insight into student understanding that enables teachers to meet students where they are on a given skill/standard. There are four core competencies embedded within each course: cognitive skills (interdisciplinary competencies- 
how we use what we know), content knowledge (common core standards), habits of success, and sense of purpose (long-term goals). The district monitors student achievement through mastery of focus areas and performance based assessment projects within each unit of study. Through the evaluation of Performance Based Assessments (PBAs), students are provided feedback based on a cognitive skills rubric that includes 36 skills spiraled across grade levels. For each skill, a student must score a six on a zero through eight scale in order to demonstrate college and career readiness. Student progress is a continuum of competency in a skill appropriate for their developmental level of growth. Grades are on a rolling basis and not final until the course is completed and mastery has been achieved. Google classroom and Edgenuity are additional tools utilized in electives, Career and Technical Education (CTE) pathways, and other required courses to personalize learning. All teachers implementing personalized learning are offering students voice and choice in their pace, path, and/or product to demonstrate mastery of a skill or standard.

\section{Data Sources}

I drew upon data collected from three sources: a student survey, student interviews, and documents pertaining to district- and school-level curriculum and instruction. I collected data initially using the Climate and Culture Middle and High School Student Survey 2019-2020 (See Appendix A). The survey tool ${ }^{1}$ collected data from multiple stakeholders for the purposes of analysis and informing decisions in pursuit of continuous improvement in schools and districts. This survey provided an overall view of student perceptions regarding the climate and culture and their experience as a student and will serve as a springboard to the more personal level

\footnotetext{
${ }^{1}$ The survey was developed by Cognia (formally known as Advanc-Ed), an organization of educators providing accreditation and certification services internationally.
} 
during the interview stage. The survey measures student engagement through student responses to items about their learning experiences. The survey consists of 20 items categorized into three components or domains of engagement: behavioral, cognitive and emotional Fredricks, Blumenfeld, \& Paris (2004). Behavioral engagement refers to a student's efforts in the classroom, while cognitive engagement examines a student's investment in learning, and emotional engagement measures a student's emotions or feelings about the classroom and school, in general. AdvancEd conducted a pilot of the survey across three states and included a sample consisted of 7,100 elementary, 6,880 middle, and 6,514 high school students with 20,494 students across demographic groups.

I collected additional data through the process of in-person, semi-structured interviews (See Appendix A for the interview protocol). I selected a purposive sample of 12 students from across grades 7 through 12 in either their second or third year of experience with the personalized learning approach. Furthermore, I selected students purposively to ensure diverse representation across subpopulations, specifically by gender, socio-economic status, students identified with disabilities and course ability groups. The interview protocol consisted of 12 questions (See Appendix B), seeking to uncover rich descriptive data on the personal experiences of participants, (Glesne, 2016). Each interview lasted approximately 25-40 minutes in length. I recorded and transcribed the data from the semi-structured interviews verbatim.

Finally, I analyzed school and district documents in order to identify the policies and practices set forth by the district in relation to personalized learning. As this is a case study about individual student perceptions of their experiences with personalized learning, these documents served as a means of triangulating data from other sources (survey and interview data). 
DATA COLLECTION SOURCE

\begin{tabular}{|c|c|c|c|c|}
\hline \multirow{3}{*}{ â. } & & From an Individual & From an Organization & \multirow{2}{*}{$\begin{array}{l}\text { Study Conclusions } \\
\text { If case study is an } \\
\text { individual }\end{array}$} \\
\hline & $\begin{array}{l}\text { About an } \\
\text { individual }\end{array}$ & $\begin{array}{l}\text { Individual behavior } \\
\text { Individual attitudes } \\
\text { Individual perceptions }\end{array}$ & $\begin{array}{l}\text { Archival records } \\
\text { Other reported behavior, } \\
\text { Attitudes, and perceptions }\end{array}$ & \\
\hline & $\begin{array}{l}\text { About an } \\
\text { Organization }\end{array}$ & $\begin{array}{l}\text { How organization works } \\
\text { Why organization works }\end{array}$ & $\begin{array}{l}\text { Personnel policies } \\
\text { Organization outcomes }\end{array}$ & \\
\hline
\end{tabular}

Figure 2. Yin's (2018) Design Versus Data Collection

\section{Data Collection Procedures}

I used secondary survey data collected by the school district as part of their ongoing program evaluation activities. Students' grades 7-12 individually complete the 20-question online survey on their Chromebooks. Survey participation was voluntary and anonymous. The data report was available through the eProve Survey platform.

I utilized existing survey data. I provided students information about participating in the interviews, including student informed consent information (See Appendix C). As these students are a protected class (minors), I also provided informed consent information to the participating students' parents or guardians (See Appendix D). I recruited participants who fit the characteristics I had specified and gauge their interest in participating in the interviews.

Students who expressed interest in participating in interviews received consent forms, approved by the University of Louisville Institutional Review Board, and were instructed to speak with their parents/guardians about study participation. Only students who returned consent forms that they and their parents signed were eligible to participate in the study. Students and parents were free to talk with me if they had any questions about participation in the research.

Finally, I collected documents for analysis. I collected curriculum documents, continuous improvement plan-TC Strategic Plan, graduate profile, walkthrough documents, and the school's 
master schedule to gain insight into the practices and policies that support (or not) student responses given in the surveys and in the interviews. These documents also provided additional context to the individualized learning intervention used within the school and district.

\section{Ethical Considerations}

Qualitative research sees study participants as critical partners in the process of the research. My research aims to understand a phenomenon (student perceptions of individualized learning). My goal is to utilize the findings to inform positive change. Conducting research in complex ever-changing environments may define action research. Researchers such as myself must be mindful of the values inherent in the process. What actions will result in the greatest good for the greatest number? The reason I point this out is because it relates to the work I am engaged in studying, as well as living. I adhere to the philosophy that where we put our energy and focus is evidence of what we value.

Completing a structured ethical reflection (See Appendix E) gave me a new lens from which to view my research work. I chose the values of trust, equality, open-mindedness, adaptability, respect, transparency, and integrity because they are at the core of my beliefs as an educator and as a leader. Equity and adaptability are values of utmost importance, as a former special education teacher and ingrained in my everyday actions in my work with my students and colleagues. I served as an advocate for the needs of my students. These two values are foundational in my current work leading my district to personalize learning for all students no matter their abilities. As I transitioned through my various roles, I added respect and integrity to the forefront of my value system. In order to continue to serve students, I learned to respect differing opinions and viewpoints while remaining true to my purpose. As I moved into the role of leader, the last three values transparency, trust and open mindedness became pillars in order to 
gain momentum and buy-in from my staff. Through the reflection of my growth as an educator, I was able to choose values to focus on during my research. The process of identifying these values and relating them to the work in which I am engaged has served as a roadmap to ensure ethical choices are made through each phase of the research process. As I conducted the research within the school system in which I work, this -was of utmost importance. I needed to honor the voices of the students I interview so I can truly gain insight into their experience as a student.

I constructed a letter explaining the purpose and scope of the study for both the student and parents (See Appendices C and D, respectively). I sent those to the parents of the potential student informants. I made follow-up phone calls to each parent to ensure their receipt of the letter. Parent consent forms explained the purpose and intention of the study as well as any potential risks or benefits. I obtained parent consent forms before engaging with their children for participation.

In accordance with the Institutional Review Board (IRB), I informed the student informants and their parents about the research process, the study's purposes, and any potential risk and benefits. I required all participants and parents to review and sign assent forms before any data are collected. Since minors serve as informants of this study and are considered vulnerable subjects, special protocols were followed. According to the Federal Policy for the Protection of Human Subjects, (2001) "children are considered vulnerable, in part because of the legal limitations on their autonomy, but also because of their presumed reduced capacity to understand and fully participate in the informed consent process" (p.17). To ensure the student participants are fully knowledgeable of the research objectives of this study, they received an informed consent form assent form (see Appendix C). These provided a clear explanation of 
what the study sought to achieve, the purpose for which the study was being conducted, their role in the study, and the utilization of the findings. The document informed the participant of their right to discontinue involvement at any time without any repercussion should they ever feel harmed by the process. Students and participants were able to withdraw from the study at any time or choose not to answer any question that they do not feel comfortable answering or do not want to answer.

\section{Data Analysis}

The process of data analysis was about "playing" with the data to illuminate trends, patterns and insights that emerge as the researcher manipulates the data (Yin, 2018). To facilitate this process, a researcher may employ several strategies. Available strategies include utilizing arrays, matrices, and visual displays, tabulating frequencies, and sequencing information. These strategies aid the researcher to cycle through the data collected.

Survey. Using existing survey results from previously administered eProve Surveys; I undertook a descriptive analysis of the data. The report generated through eProve Surveys provides bar graphs as visualizations of the data. Additionally, I also provide visualizations in the form of tables depicting the most frequent words selected by students to determine overall data trends. The tables and visualizations helped me to determine the words students most frequently used to answer each question. This survey captured the overall perceptions of all students' grades 7 through 12 regarding their perceptions of the climate and culture of the school.

Interviews. The next phase of data analysis consisted of the coding of interview transcripts. Through coding, or labeling to assign symbolic meaning to the descriptive, inferential information, (Miles, Huberman, Saldana 2014). I reviewed the transcripts using a process outlined by Saldana (2016), first at the elemental level and assign data to chunks (open 
codes) providing descriptive labels to summarize the findings. I used words or short phrases often offered by the participants, therefore utilizing an inductive process, as they emerged from data collection. In the second cycle, I developed axial codes to uncover relationships among the descriptive codes from the first cycle. In the third cycle, I utilized selective codes to elicit core values expressed by students during the interviews. I used a matrix display in an Excel Spreadsheet for the process.

Document Analysis. Additionally, analysis of documents pertaining to curriculum, instruction, continuous improvement planning and policies provided further context regarding implementation of personalized learning. A process of reading through the specified texts annotating margin notes was used to form initial codes. The codes were then be analyzed for emergence of themes or patterns and finally represented visually to develop naturalistic generalizations of what is learned (Creswell, 2018).

\section{Process for Exploring Researcher Positionality}

As Chief Academic Officer in a district, I am in a position to understand the actions of students prior to implementation of personalized learning. Milner (2007) provides a useful and oft-cited methodological framework by which a researcher may examine his or her own positionality. Milner's framework consists of four components - researching the self, researching the self in relation to others, engaging in reflection, and shifting from self to system. Researching the self requires researchers to examine their own racial and cultural experiences and perspectives critically. Researching the self in relation to others demands that researchers explore their own racial and cultural experiences and perspectives with those of others, specifically those that serve as the informants and context for their research. Reflection requires that the researcher think critically about how the diversity of life experiences may inform how various actors 
interpret a variety of situations. Finally, shifting from self to system demands that the researcher examine his or her own personal perspectives within the larger societal contexts. In so doing, the research seeks to avoid pitfalls that may adversely affect the findings of a study and how these findings may shape actions.

\section{Strategies for Ensuring Credibility, Transferability, Dependability, and Confirmability}

The level of trustworthiness and validity is reliant on what the researcher hears through the survey and interviews. During the process of conducting my structured ethical reflection (see Appendix E), the first value this researcher selected was trust. To that end, I carefully considered all viewpoints, which is critically important when conducting research in a bounded case within the researcher works. During construction of the research questions, I was mindful to keep them open ended to ensure lack of bias. During the planning and recruitment phases of the process, I clearly explained the purpose and utilization of the information to ensure that participants are informed. It is also important to adhere to the outlined process and ensure accurate representation of participant voices and that the data collected remains foundational to subsequent actions. The coding process that utilized will help to support the validity of the work presented. Credibility in qualitative research corresponds to internal validity in quantitative approaches (Morrow, 2005). The credibility of my research involved member checking to verify the accuracy of statements made during the interview. As previously stated, I electronically recorded and transcribe the interviews verbatim.

\section{Summary}

The goal of this chapter was to outline the research methods that I will use to answer the aforementioned research questions. A discussion of the research methods/design, context of the 
study, procedures, data collection and analysis, and the positionality of the researcher serve to frame the facilitation of the study. The social constructivist theory serves as the theoretical framework that grounds this research as was identified in chapter one. My lens is to uncover how the pedagogy of personalized learning fosters student growth and development as a learner constructing meaning of the world around them. Chapter 4 will provide an in-depth analysis of the results and the implementation of research methods and design outlined in this chapter. 


\section{CHAPTER 4: ANALYSIS AND RESULTS}

In this study, I explored student perceptions of personalized learning and their overall student experience. Additionally, I examined student perceptions of teachers and their fellow classmates in their learning experiences. There are four research questions, which guided this study with the first serving as an overarching driving question and the subsequent three delving into the impact on the student experience. They are as follows:

RQ 1: What are student perceptions of personalized learning and their overall student experience?

RQ 2: How have student perceptions of their role in their own learning experiences changed because of the personalized learning initiative?

RQ 3: How did student perceptions of the role of the teacher in their own learning experiences change because of the personalized learning initiative?

RQ 4: How did student perceptions of the role of their classmates in their own learning experiences change because of the personalized learning initiative?

In this chapter, I present the findings of my study. I organized Chapter 4 as follows. I first began with an exploration of my positionality as a scholar practitioner examining student perceptions and conditions of a program that administer. I utilized a Structured Ethical Reflection (SER) framework to structure the examination of my researcher positionality as outlined in Chapter 3. The next section provides an overview of the results through tables and discussion of the analysis process. There are seven tables included to highlight information presented within the text of this paper. Table 6 outlines the data sources utilized to answer each of the four research questions that define this research. Table 7 highlights the top four responses 
to each of the survey questions presented to students in each of the last two years. Table 8 and Table 9 provide details regarding the demographics of the students interviewed during the study. Table 10 offers an alignment of the selective codes uncovered in relation to each of the four research questions. Table 11 suggests an alignment of the first two documents reviewed: TCPS Strategic Plan and Graduate Profile to the Selective Codes. Table 12 demonstrates the triangulation between the selective codes (core values aligned with the literature) and the walkthrough tools utilized by the district.

I then structured my analysis of findings around the aforementioned research questions, making sure to identify the specific data sources (student survey, student interviews, and documents pertaining to district- and school-level curriculum/instruction) used to answer each research question. This chapter ends with a summary of the findings.

\section{An Exploration of Researcher Positionality}

As I explore my positionality as a researcher, I utilized the four components of Milner's (2007) framework discussed in chapter 3. I first researched myself to uncover how I came to position myself in the field of education and ultimately in a position to conduct this research. A life and career altering experience occurred during my high school experience when a close family friend ended up on the bottom of a rugby tackle, resulting in a broken neck and a life forever changed. The incident led me to wonder about his future, his education, and his ability to create a life for himself like the rest of us. The exposure to this experience and my curiosity around it enabled me to become aware of a law affecting millions of students with varying disabilities P.L. 94-142. I decided that helping them achieve their goals was what I needed to do. I served students with disabilities for the 15 years following my college graduation both in the school setting and through homebound instruction. I spent the next ten years expanding my 
proverbial classroom serving as an instructional coach, and building administrator at the middle school level. Up until now, my career focus has been in service of meeting students where they were and building supports that would enable them to achieve their greatest success. However, as my career began to change and develop, I became aware of the concept of personalized learning as an instructional pedagogy for all students four years ago when I moved to a role as an instructional leader at the district level.

The second component of Milner's framework suggested that a researcher reflect on self in relation to others. To this end, I reflected on my position and relationship to those I studied. Working for the last four years in the public school district in which this study is conducted, I am in a position to understand the actions of students prior to implementation of personalized learning. My first year in the district, we operated under a very traditional school structure. During that year, we embarked on a learning journey about personalized learning. The visits, observations, and interviews regarding the implementation process and predicted outcomes with the personalized learning approach have allowed me to embed personalized learning approaches into my daily work and I am keenly aware of potential bias with this study. The underlying premise of personalized learning in broad terms is to empower the learner to have an active voice in the learning process; therefore, the design of this study utilizes that voice by gaining insight into student perception in order to guide future practice. This design intends to mirror the instructional pedagogy it seeks to explore.

In order to achieve that parallel, I undertook a structured ethical reflection process at the outset of this process to assist in ensuring credibility, transferability, dependability, and confirmability. Through this process of the Structured Ethical Reflection (SER), I engaged in a reflection and the values that I hold. In turn, this process enabled me to shift my reflection from 
myself to the system itself. The SER provides researchers with a process for identifying core values and examining the ways in which these principles are embodied in research and pedagogical practice, (Stevens, Brydon-Miller, \& Raider-Roth 2016). Qualitative research sees study participants as critical partners in the process of the research. My research aimed to understand a phenomenon (student perceptions of individualized learning). Researchers such as myself must be mindful of the values inherent in the process. Completing a structured ethical reflection (See Appendix E) gave me a new lens from which to view my research work. This enabled the continual analyzation of any potential bias to ensure I was accurately representing student voice and adhering to the values they represented throughout the process. The goal of this study was to listen and gain an understanding of the perceptions of students that will drive further work supporting teachers as they provide relevant opportunities for their students.

\section{An Overview of Data Sources and Analytical Strategies}

I drew upon data collected from three sources: a student survey, student interviews, and documents pertaining to district- and school-level curriculum and instruction. I used secondary survey data as the initial source. I undertook a descriptive analysis of the survey data; first reviewing the bar graphs provided through eProve that illuminated the words chosen with the highest frequency as students responded to survey questions. I then created a table to analyze the patterns revealed.

I collected additional data through the process of in-person, semi-structured interviews (See Appendix A for the interview protocol). The next phase of data analysis consisted of the coding of interview transcripts. I reviewed the transcripts using a process outlined by Saldana (2016), first at the elemental level and assign data to chunks (open codes) providing descriptive labels to summarize the findings. I used words or short phrases often offered by the participants, 
therefore utilizing an inductive process, as they emerged from data collection. During the second cycle, I developed axial codes to uncover relationships among the descriptive codes from the first cycle. In the third cycle, I utilized selective codes to elicit core values expressed by students during the interviews. I used a matrix display in an Excel Spreadsheet for the process.

I collected curriculum documents, continuous improvement plan-TC Strategic Plan, graduate profile, walkthrough documents, and the school's master schedule to gain insight into the practices and policies that support (or not) student responses given in the surveys and in the interviews. These documents also provided additional context to the individualized learning intervention used within the school and district.

Table 6. Data Sources Aligned to Research Question

\begin{tabular}{lcccc}
\hline \multicolumn{1}{c}{ Data Source } & $\begin{array}{c}\text { Research } \\
\text { Question \#1 }\end{array}$ & $\begin{array}{c}\text { Research } \\
\text { Question \#2 }\end{array}$ & $\begin{array}{c}\text { Research } \\
\text { Question \#3 }\end{array}$ & $\begin{array}{c}\text { Research } \\
\text { Question \#4 }\end{array}$ \\
\hline $\begin{array}{l}\text { Student Climate and } \\
\text { Culture Survey }\end{array}$ & $\mathrm{X}$ & $\mathrm{X}$ & $\mathrm{X}$ & \\
\hline Student Interviews & $\mathrm{X}$ & $\mathrm{X}$ & $\mathrm{X}$ & $\mathrm{X}$ \\
\hline $\begin{array}{l}\text { Documents Pertaining to } \\
\text { Curriculum/Instruction }\end{array}$ & & $\mathrm{X}$ & $\mathrm{X}$ & \\
\hline
\end{tabular}

\section{Survey Results}

I collected data initially using the Climate and Culture Middle and High School Student Survey 2018-2019 and 2019-2020 (See Appendix A). This survey data provided an overall view of student perceptions regarding climate and culture and their experience as a student. The survey measured student engagement through student responses to items about their learning experiences. The survey consisted of 20 items categorized into three components or domains of engagement: behavioral, cognitive and emotional (Fredricks et al., 2004). 361of 525 students (69\%) responded to the survey in 18-19; and 169 of 530 of students (32\%) responded to the 
survey in 19-20. After graphing the response results, I identified the top four responses to each question as indicated in Table 7.

\section{Table 7. Student Survey Top Four Responses}

\begin{tabular}{|c|c|c|}
\hline $\begin{array}{l}\quad \text { Survey Question: } \\
\text { Which four of the following } \\
\text { words or phrases best } \\
\text { describes... }\end{array}$ & Jr/Sr High School 2018-19 & Jr/Sr High School 2019-20 \\
\hline $\begin{array}{l}\text { The expectations for you as a } \\
\text { student? }\end{array}$ & $\begin{array}{l}\text { I am learning- } 63 \\
\text { I should ask a teacher- } 52 \\
\text { I understand- } 49 \\
\text { I am expected to be good at some } \\
\text { things- } 43\end{array}$ & $\begin{array}{l}\text { I am learning- } 55 \\
\text { I should as a teacher- } 53 \\
\text { I am expected to be good at some } \\
\text { things- } 52 \\
\text { I am busy- } 44\end{array}$ \\
\hline $\begin{array}{l}\text { The things your teachers say to } \\
\text { you while at school? }\end{array}$ & $\begin{array}{l}\text { Explain it-54 } \\
\text { You will be working on-55 } \\
\text { We will be working on-52 } \\
\text { What are you doing-38 } \\
\end{array}$ & $\begin{array}{l}\text { Explain it-58 } \\
\text { We will be working on-50 } \\
\text { You will be working on-50 } \\
\text { What are you doing-50 }\end{array}$ \\
\hline $\begin{array}{l}\text { How you feel when trying to } \\
\text { complete your assignments } \\
\text { while at school? }\end{array}$ & $\begin{array}{l}\text { Pressured-54 } \\
\text { Rushed-53 } \\
\text { Tense-48 } \\
\text { Hurried-46 } \\
\end{array}$ & $\begin{array}{l}\text { Pressured-62 } \\
\text { Rushed-55 } \\
\text { Never enough time-49 } \\
\text { Tense-47 } \\
\end{array}$ \\
\hline $\begin{array}{l}\text { What you think of your } \\
\text { teachers? }\end{array}$ & $\begin{array}{l}\text { Honest-53 } \\
\text { Caring-53 } \\
\text { Fun-36 } \\
\text { Interesting }\end{array}$ & $\begin{array}{l}\text { Honest-49 } \\
\text { Caring-46 } \\
\text { Fun-35 } \\
\text { Active-31 }\end{array}$ \\
\hline $\begin{array}{l}\text { The things you most often do } \\
\text { while in class? }\end{array}$ & $\begin{array}{l}\text { Take tests-61 } \\
\text { Work alone-49 } \\
\text { Listen to teachers-45 } \\
\text { Think-39 } \\
\end{array}$ & $\begin{array}{l}\text { Take tests-58 } \\
\text { Works alone-54 } \\
\text { Listen to teachers-52 } \\
\text { Think-40 }\end{array}$ \\
\hline $\begin{array}{l}\text { The interactions you have with } \\
\text { adults at your school? }\end{array}$ & $\begin{array}{l}\text { Respectful-61 } \\
\text { Helpful-49 } \\
\text { Supportive-46 } \\
\text { Trusting-46 }\end{array}$ & $\begin{array}{l}\text { Respectful-56 } \\
\text { Brief-50 } \\
\text { Helpful-44 } \\
\text { Supportive-40 }\end{array}$ \\
\hline How you feel while at school & $\begin{array}{l}\text { Bored-56 } \\
\text { Tired-55 } \\
\text { Confused-46 } \\
\text { Challenged-35 }\end{array}$ & $\begin{array}{l}\text { Tired-64 } \\
\text { Bored-60 } \\
\text { Pressured-48 } \\
\text { Challenged-44 }\end{array}$ \\
\hline $\begin{array}{l}\text { The physical space in which } \\
\text { you spend most of your time at } \\
\text { school? }\end{array}$ & $\begin{array}{l}\text { Plain-51 } \\
\text { Stressful-49 } \\
\text { Comfortable-45 } \\
\text { Chaotic-38 }\end{array}$ & $\begin{array}{l}\text { Stressful-63 } \\
\text { Plain-49 } \\
\text { Chaotic-49 } \\
\text { Comfortable-34 }\end{array}$ \\
\hline
\end{tabular}

\section{Profiles of Interviewees/Students}

All twelve of the students participating in the interview portion attend Trimble County Junior/Senior High School. I selected a purposive sample of 12 students across grades 7 through 
12. Furthermore, I selected students to ensure diverse representation across subpopulations; specifically by gender, socio-economic status, and students identified with disabilities. I looked at the proportional percentage of the population of a given subgroup and invited students accordingly as shown in Table 8 . The breakdown of the individual students interviewed is included in Table 9.

Table 8. Demographics of Student Interviewees

\begin{tabular}{lccccc}
\hline & Grade level & Gender & $\begin{array}{c}\text { Lunch } \\
\text { status }\end{array}$ & $\begin{array}{c}\text { Special } \\
\text { Education }\end{array}$ & Racial Diversity \\
\hline \multirow{3}{*}{ General } & $07-17 \%$ & M-52\% & F/R-55\% & IEP-13\% & $\begin{array}{c}95 \% \text { White (non-Hispanic) } \\
\text { Population }\end{array}$ \\
& $08-19 \%$ & F-48\% & & & $0.8 \%$ Hispanic or Latino \\
& $10-16 \%$ & & & & $1.3 \%$ Other \\
& $11-14 \%$ & & & & \\
\hline \multirow{5}{*}{ Student } & $12-14 \%$ & & & & \\
Sample & $07-17 \%$ & M-50\% & F/R-42\% & IEP-8\% & $100 \%$ White (non-Hispanic) \\
& $08-17 \%$ & F-50\% & & & \\
& $09-25 \%$ & & & & \\
& $10-17 \%$ & & & &
\end{tabular}

Table 9. Demographics of Individual Students Interviewed

\begin{tabular}{lcccccc}
\hline & Referred to as & Grade & Gender & $\begin{array}{c}\text { Lunch } \\
\text { status }\end{array}$ & $\begin{array}{c}\text { Special } \\
\text { Education }\end{array}$ & $\begin{array}{c}\text { Racial } \\
\text { Diversity }\end{array}$ \\
\hline Student 1 & AT & 7 & F & FR & No & White \\
\hline Student 2 & CT & 8 & M & X & No & White \\
\hline Student 3 & MK & 11 & F & X & No & White \\
\hline Student 4 & RW & 12 & M & FR & No & White \\
\hline Student 5 & LM & 9 & M & X & Yes & White \\
\hline Student 6 & AB & 9 & F & FR & No & White \\
\hline Student 7 & MB & 10 & F & X & No & White \\
\hline Student 8 & PH & 9 & F & FR & No & White \\
\hline Student 9 & JL & 8 & M & R & No & White \\
\hline Student 10 & GG & 7 & M & X & No & White \\
\hline Student 11 & PW & 11 & M & X & No & White \\
\hline Student 12 & CV & 10 & F & X & No & White \\
\hline
\end{tabular}

Notes: F = Female; $\mathrm{M}=$ Male; FR = Free/Reduced Meals Recipient; $\mathrm{R}=$ Reduced Meals Recipient 


\section{Coding Process}

The interviews provided insight into each student's unique perspective on their experience throughout the implementation process of personalized learning. Each subsequent section of this chapter reveals their perspectives through patterns derived through the inductive coding process aligned to each of the four research questions. The coding process began through input of line-by-line statements gathered through the interview process and subsequently sorted by alignment with each research question. The first level of coding, open code, elicited tentative labels for chunks of data. Open coding in grounded theory method is the analytic process by which concepts (codes) to the observed data and phenomenon are attached during qualitative data analysis. It is one of the 'procedures' for working with text as characterized by Strauss and Corbin (1990). Open coding aims at developing substantial codes describing, naming or classifying the phenomenon under consideration. These open codes revealed the thoughts and feelings represented by students in their responses to the 12 interview questions. This level of classification enabled me to uncover relationships among the open codes through the second cycle to elicit axial codes.

During the second cycle of coding, I used deductive and inductive reasoning looking for relationship identification between descriptive open codes to elicit axial codes. Axial Coding describes a category's properties and dimensions and explores how the categories and subcategories relate to each other, Saldana (2016). In essence, I sought to identify central (i.e., axis) phenomena in the data. Links emerged between the first cycle of codes in which the researcher saw patterns develop across the data. At this point, the data revealed 39 central relationships among codes with 13 outliers not yet linked. 
I determined that a third cycle of coding was necessary to focus the relationships revealed during cycle two. I embarked on a selective coding phase, sought patterns linked to a core variable or value related to research reviewed in the literature review. Table 10 displays the links that became apparent during this process.

Table 10. Selective Codes Alignment to Research Questions

\begin{tabular}{|c|c|c|c|c|c|}
\hline $\begin{array}{c}\text { Core Value } \\
\text { (Selective Code) } \\
\text { aligned with the } \\
\text { literature }\end{array}$ & $\begin{array}{c}\text { Research } \\
\text { Question } \\
\quad \# 1 \\
\text { Frequency }\end{array}$ & $\begin{array}{l}\text { Research } \\
\text { Question } \\
\quad \# 2 \\
\text { Frequency }\end{array}$ & $\begin{array}{l}\text { Research } \\
\text { Question } \\
\quad \# 3 \\
\text { Frequency }\end{array}$ & $\begin{array}{c}\text { Research } \\
\text { Question } \\
\quad \# 4 \\
\text { Frequency }\end{array}$ & $\begin{array}{c}\text { Frequency } \\
\text { Across all } \\
\text { Research } \\
\text { Questions }\end{array}$ \\
\hline Agency & 22 & 24 & 9 & 4 & 59 \\
\hline Self-Efficacy & 6 & 12 & 1 & 0 & 22 \\
\hline Self-direction & 9 & 13 & 5 & 7 & 34 \\
\hline $\begin{array}{l}\text { Purposeful } \\
\text { Feedback for } \\
\text { mastery of } \\
\text { learning }\end{array}$ & 0 & 16 & 1 & 0 & 18 \\
\hline $\begin{array}{l}\text { Teacher } \\
\text { Centered }\end{array}$ & 8 & 27 & 12 & 4 & 51 \\
\hline $\begin{array}{l}\text { Teacher } \\
\text { Facilitated }\end{array}$ & 3 & 4 & 12 & 6 & 25 \\
\hline $\begin{array}{l}\text { Student } \\
\text { Centered }\end{array}$ & 0 & 4 & 12 & 3 & 19 \\
\hline $\begin{array}{l}\text { School } \\
\text { Connectedness }\end{array}$ & 11 & 6 & 25 & 7 & 49 \\
\hline $\begin{array}{l}\text { Implementation } \\
\text { Issue }\end{array}$ & 6 & 47 & 22 & 0 & 78 \\
\hline
\end{tabular}

\section{Student Perceptions of Personalized Learning and the Student Experience}

Questions 3, 7, and 8 of the student survey align to the first research question and provide insight into the overall student experience. These responses indicate that students may be feeling overwhelmed, as they chose the words pressured, rushed, and tense to describe how they feel when completing work. They further responded to feeling tired, bored, challenged and confused while at school. The shift to students carrying the heavy load for learning may be a contributing 
factor to these feelings. Further clarification of student perception is evident in the analysis of responses during student interviews.

The selective code or value of agency appeared 22 times in student statements across student interviews in relation to this research question. As previously described in the literature review, Student agency refers to learning through activities that are meaningful and relevant to learners, driven by their interests, and often self-initiated with appropriate guidance from teachers. To put it simply, student agency gives students voice and often, choice, in how they learn. Students are able to develop an independent, proactive approach to their studies. AT stated, "I love school, love Summit because I am independent, and like to do it myself". She described her day as a student with the following response, "We go to mentor and meet. Do work we are behind on or what we need to do. In science, we do a lot of projects. ELA a lot of projects. Good at FA (focus area) and went through them quickly. SS loved and got too move to 8th grade." CT expressed that he was self-motivated to get the work done. RW offered that he became a better student during his four years at TCJSHS. He went on to explain that he had deadlines but could work at his own pace, which helped him a lot to get things done. LM shared "I learn better if it is something I am interested in. I am better to work on my own." He went on to say, "each year has gotten better because I figured out I could get ahead. It is a good improvement." MB stated, "I am a really fast learner so a lot of the things come easy. I enjoy the program because I can work at my pace, which is fast." GG said, "Most of the days I worked on FA were workshop days. I like those days a lot. I could get more FA done. Most of it was work on your own."

The commonalities among these statements are shared sentiments regarding the ability to have choice in pace and path through personalized learning. CV expanded with, "School was 
fun, you were tired by the end of the day, six classes where you actually have to do stuff...heavier work load." She has developed a more independent positive approach to learning and spoke to the load shift from teacher to student. Some students expressed that this shift in agency was not an easy one. CV also spoke about the transition, "I am more of a hands-on learner; it has been harder with Summit because it is not as hands on as I was used to. I started it 8th grade year, that was hard because nobody knew how it worked." A few students also spoke to the relevancy piece of agency. JL replied, "I like history because I have always been interested in it as long as I can remember. Best grade I have." LM shared, "Work on the farm and I am a hard worker. I think if I don't see the relevance I have a harder time." In order to achieve agency, students must have the belief in themselves as a successful learner.

Self-efficacy is a person's sense of being able to deal effectively with a particular task, while agency is the capacity to coordinate learning skills, motivation and emotions to reach a goal. A student with a strong sense of self-efficacy has the greater capability to exert agency over their learning. I make note of this as a result a pattern noted during the coding process that reveled a frequency of six statements linked to self-efficacy in relation to this research question. The statements made by students elevated the importance of self-efficacy in reaching the level of agency associated with their experience as a student. PH stated, "I am a mix of learning styles it depends on the subject. In English, I need to write or highlight. What works best at the moment." Through this statement, she reveals an awareness of her needs as a learner and her sense of being able to deal with a particular task. In the same manner, JL revealed his understanding of himself as a learner through this statement, "I learn better when I read". He also reveals his uncertainty about his efficacy with personalized learning, "It was easier before because there was more structured time." GG expresses his confidence with his experience as a learner, "I am a good 
learner. I listen. I like hearing things mostly. I catch onto most things quickly.” PW acknowledged his learning style in relation to his experience as a learning through his statement, "Using my hands is how I learn best...just using my hands. 'I also watch and listen, but pair it with another strategy." These students all demonstrate their level of self-efficacy, which in turn influences their experience as a student. A student needs an awareness of who they are as a learner and a sense of their ability to tackle a task in order to develop agency.

Likewise, a student needs to develop the capacity to self-direct the learning process in order to reach a level of agency that empowers the student (Kallick \& Zmuda, 2016). The concept of self-direction appeared nine times across student responses. AB described her experience with personalized learning as "more of a self-taught thing". Although her perception of that experience was not one that was positive as revealed by her statement, "Pretty much on a computer the whole. Some teachers do not even speak to you". LM described the process that led to self-directed learning in that there was a release of responsibility. "During personalized learning time (PLT), the teacher announces group help time and calls small groups over or individual. The rest of the class is working independently". CT echoed this with her statement; "I take notes from resources on playlists or work on focus areas (FA) or projects. M/F is selfdirected T-TH teacher directed." Many of the student statements surrounding self-directedness pointed to the shifting role of the teacher and the student in the learning process.

My review of the extant literature revealed research surrounding the changing roles of the teacher and the student. These changes are revealed as the students responded to questions about their experience as a student. These findings are discussed to greater depth as associated with research questions two and three, but there are some important findings to note regarding 
the effect on the student experience as well. Students articulated a distinction between teacher centered and teacher facilitated instruction.

Coding revealed a pattern relating to teacher-centered instruction nine times in responses related to this research question. Their statements illuminated the challenges with the transition from their more traditional experience in the classroom to a more personalized experience. LM demonstrated this through his statement, "The first year I hated it because I was used to the whole class taught together and I fell behind". AB highlighted the differences in the transition process, "Depends on the teacher. Some teachers will tell you know what the project is about, the focus areas that come with it, and they tell you the deadline. With other teachers you rely on yourself." GG pointed out that in his experience there remains a certain amount of teacher centered instruction, "Project days were pretty structured. Teachers talked about what we were going to do and what was happening in a project and how to do the checkpoints." PW highlighted how teachers may also have some challenges transitioning to this new experience for students, "US history was a struggle. She would go through the power point, lecture for 20-30 minutes, and then say OK begin and she would sit down. Then people would talk. She would say you are not listening and she would quit. Project should have taken 1-2 weeks it took us 6 months. From beginning of the year we were behind."

Three statements linked to the transition to teacher facilitated learning in relation to their experience as a student. MB explained the process some of his teachers use to frontload and launch a project. That process enables students, through facilitation of the teacher throughout, to have agency, self-efficacy, and self-directedness. "Most teachers are pretty good about teaching the projects up front, which changed a lot from last year." He went on to say, "Some days the teacher is up and teaching and some we work on our own on projects or on computers working 
on FA's". These statements illustrate the balance teachers are trying to achieve between solely teacher-centered instruction and student-centered instruction. Their level of success with this affects the overall student experience.

Students also revealed, through their responses, the importance of the feeling of school connectedness in relation to their experience as a student. This value showed itself 11 times through the coding process for this research question. CT shared, "I like school. It is an easy place to learn. I am comfortable with most of the teachers there." RW conveyed he felt supported; "Teachers always went above and beyond". LM expressed his thoughts about school this way, "I like learning and the clubs and groups that the school has. Not much, I do not like." CV added, "I like school because of the social aspect and the teachers are super supportive." She also indicated that it was not perfect, "Now everyone is more comfortable, but it is still not ideal for all.” These statements indicate the relationship between how a student feels about school and their experience as a student.

Six additional student statements share the sentiment expressed by $\mathrm{CV}$ pointing to a pattern that reveals potential implementation issues. MB pointed out the struggle with the transition concerning what teachers do and how it affects his experience, "In 18-19 teachers did not teach projects and just told kids what to do they thought Summit taught for them. Some teachers think they do not have to teach. 19-20 was better, but is it due to different teachers or a school as a whole." He also pointed out inconsistencies that affect an equitable experience for all students, "Teachers help certain students and do not help others. One student took a FA 24 times and another got help after a smaller attempt number." PH indicated that the experience depended on the classroom and the teacher, "In English pretty much always on computer reading or writing. Science pretty much on computer the whole time every day, but we did not have a 
consistent teacher. In 4th period, I switched classes' mid-year, I did Spanish online first semester and second semester not on computer at all. In drama the only time we got on the computer was watching play backs and analyzing. In math, $\mathrm{C}$ would take us through everything. It was more guidance." These statements highlight implementation differences that affect individual student experiences.

\section{Student Perceptions of Their Role in Personalized Learning}

Questions one and five of the student survey align with the second research question and highlight student perceptions of their role in the learning process. The first question addressed whether the student is active or passive, as well as whether the teacher or the student owns the learning. Students indicated through their most frequent selection of words that they have a greater responsibility for their learning and are active learners. The responses to the second question support the answers to the first through the most frequent statements that students hear their teachers say. Students pointed out that they most often engage in such tasks as taking tests, working alone, listening to teachers, and thinking. While direct instruction by teachers serves as part of the implementation of personalized learning three out of the four top student responses, show student actions and initiative, as opposed to teacher directed.

The selective code or value of agency was evident in 24 student responses to interview questions aligned with this research question. Across responses students shared the guidance they received from teachers to support their growth and development of their agency over their learning. Some of the open codes that led to this selective code included feeling empowered, feeling supported, feeling in control, choice, self-paced, and the student's role. AT talked about the resources within the Summit platform. "Teachers now explain what we have to do and we take the content and learn for ourselves. You can always ask for help. I like this much better. 
Love that we are able to switch have more choice and voice." CT expanded on this, "I am doing more work now. I did not learn much when teachers stood up and told us. We can ask teachers for help and they will walk us through.” RW spoke of his feeling of control this way, "Absolutely best sense of where I stood. I had control of if I did good or not. It's all there right in front of you If you fail it is your fault." LM also shared the feeling of control, "In math I was three weeks ahead and English a month behind. More of a solid school day and could work on what I needed. I have more freedom and choice to do what I need to do.” MS expressed his sense of responsibility that was not as evident prior to personalized learning, "I don't like to stay with my class and tend to go ahead. I learn on my own that is more my responsibility." PH saw this as a real positive; "you can get ahead and plan out what you want to do on specific days. You can track what you are doing better and improve your grade."

The importance of the concept of self-efficacy appeared across 12 statements as students detailed their perception of their role in the learning process with the implementation of personalized learning. AT shared, "Teachers gave samples, but I did it my own way.” AB discussed her confidence in her decisions about learning, "Personally prefer reading not videos. I focus on my learning style and then use videos if I absolutely need them." PH discussed her level of self-efficacy as dependent on the class, "I feel like I am learning more in some classes." $\mathrm{JL}$ recognized the change in the perceived level of difficulty and the impact on his level of confidence, "Before Summit it was a bunch of simpler stuff and paper pencil. It is harder to study now." GG shared the sentiment of student nine, "Some things I feel I am learning more and some less." The previous student responses during interviews characterize the changing role of the student in relation to their level of self-efficacy. CV summarized this nicely in her statement, "Everybody had certain standards and we tried to reach those to impress them and 
now we are trying to impress ourselves." There appears to be a strong connection between the level of self-efficacy the students feel and the level of agency they perceive.

Another pattern that emerged in relation to research question two surrounded the notion of self-directed learning and their role as a student. Students pointed to this aspect across 13 interview question responses. JL expressed it this way, "There is more work load on the students. Before teachers walked you through the steps and helped with the process on papers." MB took that idea a little further stating, "Part of Summit is learning to teach yourself to use your background knowledge." MK also noted the shift to more self-directed learning, "We have to get our work done our teachers cannot do everything for us. You have to at least try to do the work and learn." AT talked about her increased role in the learning process, "You have to learn how to take notes and study to pass focus areas. Have to study more than you did before. I learned how to do that on my own." According to these statements, students have taken a more active role in the learning process than was their previous experience.

Another shift with the implementation of personalized learning surrounds the manner in which students and families gain insight into their progress in school. Purposeful feedback appeared 16 times across student responses. LM described it this way, "I feel like I understand where I stand in class based on feedback based on the score and explanation, as opposed to just a grade and they tell you how to fix it." RW expanded this idea, "With projects the feedback is most helpful, the teachers will tell you what you missed and point out what I need to do and direct me to resources. I like to have the rubric in front of me because it told me exactly what I needed to do." CT elaborated further saying, "Request feedback on a checkpoint and teachers will explain what we did wrong and how we can fix it. I get more individualized support.” However, while students appear to have a clearer picture of their level of mastery of learning, it 
has not been without challenges. Students shared many inconsistencies. AT explained, "Depends on how good the feedback is. The more explanation the better just fix it does not work." JL pointed out the success level of the feedback as being teacher dependent, "Some teachers use the rubric. Some just do the colors (red, yellow, green) and some give more specific feedback." However, in all cases, whether a pro or a con, notice that students have a greater insight regarding their progress and their ownership in doing something with the feedback. The grade is no longer an end-point for the student; therefore the student responsibility and ownership for learning has increased.

Students also illuminated the shift from a teacher-centered (27) environment to a studentcentered (four) environment on their role in the learning process. AT shared her school experience before personalized learning, "The teacher showed everything on SMART board and everything was done whole group. Teachers led all the work." She went on to say, "Before summit we depended on the teachers to give us all the information." CT echoed AT's remarks, "Teachers always in front talking to us. It was whole group versus individual. Whole group was ok but could not work ahead and some days I was bored and did not do anything.” MK described it this way, "Teachers were teaching, we did book work, took notes, did papers, wrote on the white board, and did slide shows." MB shared the same sentiment as his peers and identified his role this way, "Sit listen to teacher and raise hand. Everyone was doing the same thing. Teacher decided on the pace". PH repeated the pattern, "Everyone went at the same pace, there was nobody getting ahead." According to PW, "We did work sheets every day and it was very routine", there was redundancy in his role as a student. These students through their words demonstrate that they were passive learners and the teacher held the responsibility for the learning and carried the heavy load. 
Students described that the transition to a more student-centered, teacher-facilitated environment was challenging for all, as it was a dramatic shift. CV made a stark contrast. "Before I felt like the teachers were responsible for our education and if we understood or not. Not in a bad way, but a good way not if you do not get it oh well." She had this to say about the transition, "Students are placing blame on teachers for not doing things...kids do not want to blame themselves. We are not willing to accept that it is our fault." This exemplifies the struggle with the shift in ownership of learning. She also acknowledged that mentors helped with the transition, "Mentors help with that...what is your plan or deadline. Goal setting and planning." $\mathrm{PH}$ articulated the role shift as a comparison, "It was more teacher directed before. It is now more on the student in a way."

School connectedness, while not as prevalent as other patterns, evidenced itself across six student statements. School connectedness is the belief held by students that adults and peers in the school care about their learning as well as about them as individuals. Students are more likely to engage in healthy behaviors and succeed academically when they feel connected to school. Student's conveyed the importance this sense of connectedness plays in student's perceptions of their role as a learner. MK described the effects of a lack of connection, "I was made to feel like a nuisance. In some classes more so than others." However, in stark contrast, he also stated, "Felt valued by Ms. C- my cross country coach. We had a relationship, and she did not pick favorites." GG expressed the change that mentoring had on his connectedness to school, "I met with my mentor every other week to talk about what I needed to get done and if I was struggling with anything. I enjoyed mentoring." These statements exemplify the importance students place on knowing that someone cares about them and is there for them. 
The most frequent pattern across student responses, appearing 47 times, surrounded what students identified as implementation issues. Many of their frustrations with implementation surround the inconsistencies and the learning curve involved with many aspects of personalized learning. These inconsistencies led to uncertainty of their role as a student in the process. AB shared confusion about what she was to do based on the varying levels and timeliness of feedback, "Detail varies some just give red-yellow-green. Some go over the rubric before the project...they will tell you what they want- read through it- explain certain things if they do not make sense. Rubrics are there as a reminder." She went on to say, "On projects, when you get your feedback and grade, certain teachers give you three times to redo based on feedback. After the third time, some will want it done correctly." She further explained, "FA-depending on the teacher some require notes, others just require you to take it another day. Cannot take it twice in one day. Some teachers after certain number of test will give you a study guide or sit with you. If FA is behind a couple months they might do a workshop." She articulated the challenge of different teachers handling the process in different ways, which influenced the way in which she approached her role as a student.

I further explored documents related to curriculum and instruction that directly correlate with the student experience. The first document, TCPS Strategic Plan (Appendix F), identified Achieve Excellence in Academics as the first priority of the district. It identified the following goal statement: Students who earn a diploma from Trimble County Schools will be: selfmotivated, resilient and persevere through challenges, confident, innovative problem solvers, critical thinkers, effective communicators, goal-driven, leaders who are ready for post-secondary education/ careers, and service oriented citizens. 
Table 11. Strategies to Achieve Academic Excellence Aligned to Selective Codes

\begin{tabular}{|c|c|c|}
\hline $\begin{array}{c}\text { Core Value } \\
\text { (Selective Code) } \\
\text { Aligned with } \\
\text { Literature }\end{array}$ & $\begin{array}{c}\text { Strategic Plan- } \\
\text { Strategy to Achieve Academic Excellence }\end{array}$ & $\begin{array}{l}\text { Graduate Profile } \\
\text { Competency }\end{array}$ \\
\hline Agency & $\begin{array}{l}\text { All students will have the opportunity for } \\
\text { personalized learning. }\end{array}$ & $\begin{array}{l}\text { Think Critically to } \\
\text { Problem-Solve } \\
\text { Leadership to } \\
\text { Empower Change }\end{array}$ \\
\hline Self-Efficacy & $\begin{array}{l}\text { Staff and student's actions, language, and behaviors } \\
\text { will demonstrate a growth mindset. }\end{array}$ & $\begin{array}{l}\text { Resilience to } \\
\text { Persevere }\end{array}$ \\
\hline Self-direction & $\mathrm{XX}$ & $\begin{array}{l}\text { Motivate to Take } \\
\text { Initiative }\end{array}$ \\
\hline $\begin{array}{l}\text { Purposeful } \\
\text { Feedback for } \\
\text { mastery of } \\
\text { learning }\end{array}$ & $\begin{array}{l}\text { All students will monitor their own learning using } \\
\text { rubrics and exemplars to review and revise their } \\
\text { work. } \\
\text { Teachers will provide targeted Instruction and } \\
\text { specific feedback based on relevant student data to } \\
\text { support students' academic growth. }\end{array}$ & $\begin{array}{l}\text { Be an Effective } \\
\text { Communicator and } \\
\text { Collaborator }\end{array}$ \\
\hline $\begin{array}{l}\text { Teacher } \\
\text { Centered }\end{array}$ & $\mathrm{XX}$ & $\mathrm{XX}$ \\
\hline $\begin{array}{l}\text { Teacher } \\
\text { Facilitated }\end{array}$ & $\begin{array}{l}\text { All students will have opportunities to engage in } \\
\text { academic dialogue to make meaning, determine } \\
\text { importance, and increase understanding. } \\
\text { All students will have collaborative opportunities } \\
\text { (project based learning) that will foster creativity } \\
\text { and develop problem-solving skills in real-world } \\
\text { situations. }\end{array}$ & $\begin{array}{l}\text { Be an Effective } \\
\text { Communicator and } \\
\text { Collaborator }\end{array}$ \\
\hline Student Centered & Classroom communities will be student centered. & $\mathrm{XX}$ \\
\hline $\begin{array}{l}\text { School } \\
\text { Connectedness }\end{array}$ & $\begin{array}{l}\text { All students will have a go-to adult (mentor) to set } \\
\text { personal and academic goals with on a weekly } \\
\text { basis. } \\
\text { Through community partnerships, students will } \\
\text { engage in service projects to enhance and embrace } \\
\text { their larger community. }\end{array}$ & $\begin{array}{l}\text { Excel in Service } \\
\text { Oriented Citizenship }\end{array}$ \\
\hline $\begin{array}{l}\text { Implementation } \\
\text { Issue }\end{array}$ & $\mathrm{XX}$ & $\mathrm{XX}$ \\
\hline
\end{tabular}

In reviewing this document, I was able to connect student statements directly to the outlined goals and strategies, as well as to the selective codes and values recognized during the coding process as outlined in table 11. The second document, TCPS Graduate Profile, found 
embedded within the Strategic Plan document further identified the expected outcome for students as a requirement for graduation that resulted from this work. Table 11 displays the connections found through triangulation of the data among the interview data and documents reviewed for the second research question. It is important to note that table 11 does not identify the implementation issues raised during student interviews. While the connections exist, the fidelity of implementation or lack thereof affects the student's perceptions of their role in the learning process.

\section{Student Perceptions of Teachers in Personalized Learning}

Responses to survey questions two, four, and six helped me to begin to unpack how students view their teachers and their role in the learning process. Students indicated through their word choices, that their teachers are honest, caring, fun, and active. They chose the words respectful, helpful and supportive to acknowledge their interactions with adults in their school. They also identified the following phrases their teachers used as most prevalent: explain it, what are you doing, you will be working on, and we will be working on. Less than $20 \%$ of students chose phrases that were directive or judgmental in nature. Student word selections indicate a classroom environment that actively involves students and that teachers in general have built a community for learners that is positive.

The concept of agency (nine statements) appeared less frequently in relation to student perceptions of their teachers with the implementation of personalized learning. The majority of the statements centered on the pacing aspect. AT offered, "I do not have to wait on others to complete work". CT added, "You can go ahead when you are ready". LM addressed the choice in path, "Now I can use different resources to understand". MB talked about the load shift from the teacher to the student, "A lot more research is required and we have to use our brains a lot 
more". These statements reflect the student's view that agency plays in the shifting role of the teacher. The sense of agency empowers them to take more ownership in the learning process.

While self-efficacy only appeared one time during the student interviews regarding the role of the teacher, the quote speaks to the empowerment the students expressed. CT shared, "I am definitely learning more now". The sentiments of agency from above, coupled with this statement of self-efficacy point to the shift from a teacher controlled learning process to a student controlled and more self-directed learning process.

Student responses further expand on the power of self-directed learning. RW professed, "Summit helped prepare me for JCTC where for the most part you are out on your own. College they just give it to you." PH added, "Now there is more independence". JL echoed this sentiment, "Days working on focus areas it is more independent work". These statements further reflects the changing role of the teacher in the learning process. As independence increased, teacher reliance decreased.

The shift from a teacher-centered environment (12 statements) to a teacher-facilitated environment (12 statements) revealed itself in student responses to questions regarding the role of the teacher. RW purported, there was more lecture before Summit. I do better without so much lecture. I would get sleepy hard to focus." MK alleged, "Teachers just told you what to do". PH felt that notion was not necessarily a bad thing, "There was more communication in how you would do something. Teacher would walk you through things more." MB added, "A lot more actual teaching. The teacher got to choose the way that they taught and what they teach." These reports highlight the control and centeredness on the teacher's role in the learning process and who previously carried the learning load. GG alludes that this may not have always been viewed in a positive light, "We mostly did work together and if we didn't finish we had to 
go to office hours. We had to do everything together and it was annoying because I was always ahead." PW concluded, "We did a lot of sitting in SS. She would do her PowerPoint and that was it." CV described it this way, "Before teachers were more in charge. Everyone did everything at the same time."

Students have clearly noticed the shifting teacher role. RW noted, "I think Summit helps the teachers too because they know what they need to teach and everything the student does." JL distinguished the difference stating, "They now have a profile and details about what they are doing and they have more information about how to help students. Get more one-on-one help than before." He added, "On project days we work on checkpoints and teachers guide." A clear depiction of the difference in the role of the teacher. MB outlined what that guidance looked like, "Most get up in front of smartboard with a project up and go through the checkpoint, what is going on in checkpoint, and information need to know or need to research to complete the checkpoint." He also spoke about targeted support that teachers now provide, "Some bring up FA and directly teach if many students are struggling. Some teachers do this with every FA and that is really helpful."

Students illuminated student-centeredness as a further shift in teacher practices with a frequency of 12 . The term student-centered learning refers to a wide variety of learning experiences, instructional approaches, and academic-support strategies intended to address the distinct learning needs, interests, aspirations, or cultural backgrounds of individual students and groups of students. RW highlighted this with his statement, "Teachers offer a lot of help and lean you toward what resources to look at. More one-on-one time with Summit than before." LM articulated exactly what this might look like, "Red-yellow-green. These students can do this; these students are behind- grouping based on what was needed." He added that students also 
serve in this support role, "Mr. S would let me help other students who might be behind. Other kids understand more and can help those who struggle." This indicates the increased awareness of individual student learning needs and providing support in a variety of ways. He continues to add to this idea, "It is more catered to each student and their needs." AB indicated, "Some teach small groups or meet with individual students." JL indicated this as a positive, "It has gotten a lot better. Before Summit, teachers could not help you as much." Student responses indicated students value the support they receive and the focus of learning meets their individual needs.

The most frequent value, school connectedness, appeared 25 times across student statements. AT linked student-centeredness and school connectedness in her statement, "One-on one attention has increased and more comfortable asking questions because I know them better." CT offered, "Closer with mentor teacher than any other teacher. That is my go to person. Mentoring is a pretty big advantage." RW described mentoring in further detail, "Every M or F have mentor groups and meet with them individually 1-2 times per month. They check in about grades and they stayed on you to help you get stuff done." AB offered that even with its challenges, that mentoring had a real benefit, "During mentoring she struggled with tech, but teacher would call each up individually and pull up grades and do goal setting and she would track progress." She added, "I have a few teachers that I know I can talk to. Mentoring is the biggest change, it gives you the opportunity to be close to a teacher; someone really knowing what you need and support you in keeping up with things and prioritizing." MB said that mentoring is not only about one-on-one support, "We have discussions with our whole mentor group and talk about what is going on in school." PH put it this way, "A few teachers who are very good can interact easily easy to talk to; they care about their job and students and will do anything to help. More teachers care about the job and know how to interact with kids than 
teachers who do not show they care. There are a few top notch and we need more of these." In essence, mentoring has helped to foster stronger relationships with teachers. JL describes the power of caring, "Mr. W was easy to talk to and hands on. He helps a lot of kids and he cares." If there was ever a shot at there being a magic bullet in education, relationships-relationshipsrelationships. This notion resounded across student statements regarding the role of the teacher.

Students were transparent about what they would like to see changed with the implementation of personalized learning. Implementation issues rose to the surface 22 times in terms of the role of the teacher. $\mathrm{AB}$ began a resounding pattern that evolved, "It depends on the teacher. Some have favorites and some you do not get along with and some you connect with.” MB agreed, "Depends on the teacher. Some pick favorites." This extends beyond the core classroom to mentoring as well, "Second hand I hear mentors do not actually mentor, they sit and the kids just work on their own. It has been 3 months since I met with my mentor. It should be a helpful tool and a lot of kids are missing that because of who their mentor is." PW pointed out a more concerning scene, "The teacher sits in the corner on the phone." He added, "Mr. B started off great, but then it faded as he realized some kids did not care and he made assumptions." $\mathrm{He}$ concluded speaking about the power of the reciprocity of energy from teacher to student and back, "When it is a good class and a good teacher it seemed more involved and alive. The teacher interacted as a group and conversations were with multiple people; and ideas would flow." However, CV described what happens when that is lacking, "They sit there quietly which makes you scared of them. Depends on the teacher some I had before. Some are more open than others are. It depends on the teacher, some would walk around and others sit at their desk and make you come to them during self-directed learning time." She continued very transparently expressing her feelings, "Some did a really good job that you understood; some it was like a job 
to them they were not having fun. It did not feel like they were doing something they enjoyed, like they are just paid and then leave and some didn't do much." Students clearly reflected on the inconsistencies with implementation, the impact of which will be further discussed in Chapter 5.

I further explored documents related to curriculum and instruction that directly correlate with the student perceptions of the teacher's role. The curriculum policy set forth by the school's Site Based Decision Making Council (SBDM), approved Summit as the learning platform serving as the basis for curriculum and instruction. The district utilizes walkthrough tools to monitor effectiveness of teacher practices and implementation of instructional practices. The tools utilized align with the Effective Learning Environments Observation Tool (ELEOT ${ }^{2}$ ) tool designed by Cognia (Appendix G). The purpose of this tool is to help you identify and document observable evidence of classroom environments that are conducive to student learning. In conjunction with the ELEOT, the district walkthrough tool is also aligned with the Summit Look For's ${ }^{3}$ (platform discussed in the context section of this paper) walkthrough document. Table 12 demonstrates the triangulation between the selective codes (core values aligned with the literature) and the walkthrough tools utilized by the district.

\footnotetext{
2 The walkthrough tool was developed by Cognia (formally known as Advanc-Ed), an organization of educators providing accreditation and certification services internationally.

${ }^{3}$ These look-fors and strategies help educators and their coaches take the most appropriate actions - before, during, and after instruction - so all students thrive in the Summit Learning Program.
} 
Table 12. Walkthrough Tools Aligned to Selective Codes

\begin{tabular}{|c|c|c|}
\hline $\begin{array}{c}\text { Core Value } \\
\text { (Selective Code) } \\
\text { Aligned with } \\
\text { Literature }\end{array}$ & ELEOT Domain & Summit Look For's \\
\hline Agency & $\begin{array}{l}\text { High Expectations Learning } \\
\text { Environment }\end{array}$ & Collaboration \\
\hline Self-Efficacy & $\begin{array}{l}\text { High Expectations and Supportive } \\
\text { Learning Environment }\end{array}$ & Customization \\
\hline Self-direction & Digital Learning Environment & $\begin{array}{c}\text { Rigor } \\
\text { Purposefulness }\end{array}$ \\
\hline $\begin{array}{l}\text { Purposeful } \\
\text { Feedback for } \\
\text { mastery of } \\
\text { learning }\end{array}$ & $\begin{array}{c}\text { Progress Monitoring and Feedback } \\
\text { Environment }\end{array}$ & Purposefulness \\
\hline $\begin{array}{l}\text { Teacher } \\
\text { Centered }\end{array}$ & $\mathrm{XX}$ & $\mathrm{XX}$ \\
\hline $\begin{array}{l}\text { Teacher } \\
\text { Facilitated }\end{array}$ & Supportive Learning Environment & Collaboration \\
\hline $\begin{array}{l}\text { Student } \\
\text { Centered }\end{array}$ & Active Learning Environment & $\begin{array}{c}\text { Customization } \\
\text { Relevance }\end{array}$ \\
\hline $\begin{array}{l}\text { School } \\
\text { Connectedness }\end{array}$ & Equitable Learning Environment & Community \\
\hline $\begin{array}{l}\text { Implementation } \\
\text { Issue }\end{array}$ & XX & $\mathrm{XX}$ \\
\hline
\end{tabular}

As noted during the discussion of evidence for research question two, these additional documents support the goal of the district to achieve academic excellence through personalized learning; however, students report numerous implementation issues during the interview process that affect the student experience. This selective code revealed itself 22 times across student statements as previously indicated. While the intentions and the plan appear to be in place, there exist implementation issues, the impact of which will be further discussed in chapter 5. 


\section{Student Perceptions of Peers in Personalized Learning}

My final research question explores student perceptions of the role of their classmates in the learning process. While the survey did not directly address this question, the analysis of interview responses provided insight to this research question. The survey results provide an initial view of the climate and culture of the school and a foundational understanding of students' perspective of their school experience.

Students reflected more deeply when speaking of their perceptions of themselves as learners and the role of their teachers in the process. Their responses in terms of their peers showed minimal differences between the more traditional environment and the personalized learning environment. They presented an overall sense that there were no significant changes in terms of peer relations, interactions, or involvement in their learning experience with the implementation of personalized learning.

The value of agency did present itself four times across student responses. AT shared, "I like doing things on my own." RW expressed, "My friend group likes it. They are more selfpaced kind of people. Some people do not like it because they like to be directed, but everything is there that you need." In terms of student perceptions of peers, students talked mostly about whether their peers liked the personalized learning approach as opposed to whether or not the approach changed their perceptions about the environment.

Self-efficacy did not appear as a selective code or value for this research question. However, self-directed was noted in terms of the impact on peer interactions within the classroom environment. MK indicated that on days or class periods when students were independently working on projects or focus areas, there was limited interaction with peers. $\mathrm{AB}$ shared there were some opportunities for partner work on both project days and focus area days. 
JL put it this way, "There is less interaction than before. Everyone is doing different things." GG lamented the fact that peer interactions were more limited during class, "Used to do a lot of group work other than math. I love group work because we can help each other. I would like to see more of this,"

While students expressed some negative feelings about the change, at the same time when they reflected on previous opportunities in the traditional classroom, they found more similarities than differences. The statements that aligned with the selective code, teacher centered, painted a similar picture to the scenarios previously described. CV said, "We did not have time to talk because the teacher was always talking." PH conveyed, "Every once in a while teachers would let students work together. JL offered, "There was paperwork that we were all doing at the same time so a lot was completed together." RW articulated, "During lecture, there wasn't as much time for interaction or small group work. We listened to the teacher and then we did our work. Sometimes there was a group project. It depended on the class and the teacher." As students further unpacked their experience through the set of interview questions aligned with research question four, the concept of teacher facilitated became a shift in the conversation. LM shared, "Most teachers give time to work with peers. On project days we can work in groups." PH presented a noticeable difference from her previous statement, "Depending on the subject, we get to work in small groups or with partners especially with projects." PW reflected and added, "There were times to talk, times for small group work and rearrange our desks, and for support through checkpoint rotations.” The contrast between the teacher-centered instruction in which the teacher led and guided through a systematic process and the teacher facilitated where the teacher's role becomes that of a facilitator and organizer providing resources and support to learners is notable in student statements. 
CT set the stage with his statement identifying the transition to a student-centered environment, "We used to do whole class now we do small groups. Now we are grouped by what we are working on or what we need help with." LM took this sentiment even further to say, "In each class we have in depth conversations about what we are learning and bounce ideas off each other. It is not just about taking notes." He expanded on this idea, "I get to talk about what I think, ask questions and process by having conversations with different people." It is interesting to note how student responses demonstrate this gradual release of responsibility process through their words and thoughts.

\section{Summary of Findings}

As I reviewed the comments aligned with the selective codes and reflected as to how they answered the research questions, the transition students have experienced from the traditional to the personalized learning approach is evident. As you look across the statements in each prior section and analyze what they said in relation to the selective code or value inductively and deductively concluded, you actually "see" the change process in action. The student statements surrounding agency reflect the dependence on self-efficacy and self-directedness in order to achieve agency. Their statements comparing and contrasting the teacher centered, teacher facilitated, and the sense of an increasingly student centered environment demonstrate the true transformation process that has occurred and obviously continue to occur. The students also voiced a clear understanding of the issues with implementation and offered some practical ideas for solutions.

Oftentimes we do not give students the credit they deserve for understanding the impact of the classroom and school environment on their learning process. This may in part be because in the traditional school structure, educators tend to place more emphasis on decisions that affect 
adults more so than the students themselves. However, students are extremely intuitive and demonstrated through their responses a keen understanding of the implementation issues during the transition process. Chapter 5 will provide a summary of findings in relation to implications. 


\section{CHAPTER 5: SUMMARY OF FINDINGS AND IMPLICATIONS}

In this study, I sought to answer four research questions. These were:

RQ 1: What are student perceptions of personalized learning and their overall student experience?

RQ 2: How have student perceptions of their role in their own learning experiences changed because of the personalized learning initiative?

RQ 3: How did student perceptions of the role of the teacher in their own learning experiences change because of the personalized learning initiative?

RQ 4: How did student perceptions of the role of their classmates in their own learning experiences change because of the personalized learning initiative?

In this chapter, I present a summary of the findings for each research question. I then discuss the implications of my findings for policy, practice, and future research.

\section{RQ 1: Student Perceptions of Personalized Learning and their Overall Student Experience}

The first research question I sought to explore revealed the student perceptions of the implementation of personalized learning on their overall experience as a student. It was interesting to see the juxtaposition across their responses to the Culture and Climate Survey and their responses to the interview questions aligned with this research question. In the survey, they indicated feeling overwhelmed through their word choices of pressured, rushed, tense, tired, challenged, and confused. This aligns with the shift from the teachers carrying the heavy load of learning to the students carrying the load. The interviews provided insight into the underpinnings of these feelings. 
Looking across the 12 interviews and coding of the responses, agency appeared as the most frequent selective code (core value). Student agency affords students voice, and often choice in how they learn (Deed, et al. 2014). Across student responses, they expressed a sense of empowerment. The words and phrases they used in their responses were positive in nature and provided the sense that they felt more control in the learning process. As shared in chapter 4, the juxtaposition was clear as CV expressed, "School is fun, you were tired by the end of the day, six classes where you really have to do stuff...heavier work load". Learning is hard work; however, these students expressed they are up for the task.

The following selective codes (core values) that revealed themselves through the coding process related to the tools that students need to acquire in order to achieve the level of agency that will support students in achieving a positive experience through implementation of personalized learning. Students pointed to self-efficacy and self-directedness as two such competencies they need in their proverbial tool kit. Their statements revealed an awareness of their needs as a learner and sense of being able to deal with a particular task, in addition to the ability to engage in the task on an independent level. Again, this reveals the juxtaposition to the feelings shared in the survey. If students have not developed self-efficacy and self-directedness, the active engagement and shift to increased student agency is a challenge.

Students also exposed their challenges with the transition from their more traditional experience in the classroom to a more personalized experience. The shift from teacher-centered to teacher-facilitated and student-centered has not been without its frustrations. Their statements illustrated the importance of balance in delivery modes and the effects on their experience as a student. The implementation issues pointed out by students highlighted inconsistencies that have affected an equitable experience for all students. In general, students alluded to the discrepancies 
in the release of responsibility to the student and the levels of support they were provided. Some teachers released students with little to no support and they were left with no guidance to build their capacity for self-efficacy and self-directedness. They also pointed to a certain level of favoritism that exists among some teachers in how much support they give and to whom.

There exists a new level of transparency with the implementation of personalized learning, which students may not have explicitly shared, but exists implicitly through their statements. The teacher no longer leads the whole class in instruction, students are not all doing the same things at the same time, and there now exists a feedback loop that enables students to reach mastery as opposed to seeking, or not, a certain grade. This level of an individualized approach illuminates things that were never before so easily revealed. This can elicit a positive result for the student experience, but only if there is a keen awareness on the part of the teacher. If the teacher blindly proceeds in the same manner of student interaction as before, they may unintentionally be, in fact, harming the student environment, as pointed out through student statements.

One way students shared to mitigate this is through school connectedness. This was the second most frequent selective code (core value) revealed through student responses. It highlighted the importance of relationships. When they spoke about relationships in response to this research question, they were not just referring to interpersonal relationships, but more about their relationship with the school itself as an entity. More importantly, how those feelings affected their overall experience. Those feelings about school tie directly back to the other selective codes (core values) discussed in this section. Overall, student responses to this research question revealed implications about practice that may foster a more inclusive and productive learning environment for all students. These will be explored later in this chapter. 


\section{RQ 2: Student Perceptions of Changes in their Role in the Learning Experience}

In contrast to the results from the first research question, as I translated the results from the survey and interview responses to my second research question, I uncovered a parallel. The survey revealed through most frequent word choice selections that students hold a greater responsibility for their learning and are more active learners than was the case in the more traditional setting. This highlights the shifting role of the student from a more passive learner under control of the teacher, to a more active learner who feels the weight of their role in the learning process.

Student responses across the interview questions aligned with this research question, supporting this notion. The selective code (core value) of agency appeared 24 times during the coding process in relation to this research question. The open codes related the feeling of empowerment, support, control, choice, and ownership were key concerning a student's sense of agency. They can now see the path for learning laid out in front of them for the entire year, whereas in the traditional classroom they were allowed to "see" only the portions of the curriculum and work that the teacher gave them at any given point of time. Students expressed how they are now able to individually pace and "get ahead" if they so choose.

Similarly, they expressed positive feelings about their self-efficacy in terms of having more control over the way in which they learn. Through their opportunities to engage with a playlist and to choose the learning mode that matches their preferred learning style. This opportunity enabled them to take increased ownership and an active role in the learning process. This further supported the transition of the perceived power a student feels as it pertains to personalized learning. In Chapter Four, one student summarized it this way, "Everybody had certain standards, and we tried to reach those to impress them and now we are trying to impress 
ourselves". A sense of self-direction was almost equally important to students and further supported the sense that students have taken a more active role in the learning process than was their previous experience.

Purposeful feedback, while not an aspect brought forward by students in response to the first research question, appeared 16 times across responses to their role in the learning process. Purposeful feedback, according to student responses, supports their ability to have agency and self-direction. One student succinctly summarized the role of feedback, "I feel like I understand where I stand in class based on feedback based on the score and explanation, as opposed to just a grade and they tell you how to fix it". Fellow students interviewed echoed this sentiment and expressed that individualized support empowers them to take a more active role in their learning. While purposeful feedback is a powerful tool as students take the helm, student responses highlighted implications for practice to increase its effectiveness. These will be discussed later in this chapter.

As was evident in the discussion of the first research question, students illuminated challenges with the shift from a teacher-centered environment to a student-centered environment. Students made it clear that in their previous role, they were passive learners and the teachers held the responsibility for the learning. They also made it clear that this shift presents a challenge, as they may not be willing to accept the responsibility that comes with this shift. Previously the failure or success of the outcomes of their learning fell on the teachers, and now with more student control they own their failures or successes. As found in the results of the first research question, students responded that school connectedness has a profound influence over their perceptions of their role as a learner. Students exemplified the importance placed on knowing 
that someone cares about them and is there for them as they navigate this new level of ownership.

Again, while students perceive increased empowerment and ownership with the implementation of personalized learning, they identified implementation issues that present barriers to these values successfully affecting their experience as a student. Many of their frustrations continue to surround the perceived inconsistencies with implementation that led to uncertainty of their true role in the learning process. In essence, in order for the student to be successful in this type of learning environment, their perceived role and their true role require alignment.

TCPS documents indicated a plan to mitigate the implementation issues through the strategic plan and graduate profile competencies that align with the selective codes (core values) presented across student statements. While those connections may exist, the fidelity of implementation or lack thereof affected student perceptions of their actual role in the learning process. I will explore these further in the implications for practice section of this chapter.

\section{RQ 3: Student Perceptions of the Teacher in the Personalized Learning Initiative}

One interesting outcome of the analysis of the responses to interview questions aligned to research questions two and three was the analogous nature of student perceptions of their role to their teacher's role in the personalized learning initiative. Student responses to the survey again presented the classroom environment with personalized learning as one that actively involves students. This was evident through the most frequent phrases used by their teachers. Statements like explain it, you will be working on, and we will be working on were the most frequently chosen from the selection offered to students. These phrases indicate the shift from the teacher 
controlled classroom. They perceive their teachers as serving in a more supportive role than was previously held.

Student interview responses provide a parallel picture of the changing role of the student and the teacher. As was revealed in the previous research question, there is a relationship between the perceived roles of the student and the teacher in the learning process. As the student's role increased, the teacher serves more as a supporting role as opposed to a leading role. As a result, the concept of agency appeared fewer times in terms of the student perception of the role of the teacher, than it did in terms of the role of the student. However, students did speak about independent pace and the shifting weight of the learning from teacher to student.

Student responses directly linked agency, self-efficacy, and self-directedness to the changing role of the teacher. As independence increased for the student, teacher reliance decreased. The caveat here though, is that students' success with this shift depended upon the level of capacity of self-efficacy and self-directedness the students perceived. Student statements set a clear distinction between what teachers actions consisted of prior to the implementation of personalized learning. Teachers were definitely in control. They controlled what was learned, when, and to an extent to what level as determined by the grades assigned to student work. Students completed the same work, in the same manner, uses the same resources. Students offered that with the implementation of personalized learning that teachers now have a profile and details about what students are learning and that they have more information to help students. Students also pointed out that they felt they were getting more individualized support as a result. Students also highlighted the feedback loop as a key to this support. Students attributed much of this to the implementation of mentoring and strengthened 
school connectedness. Those students that have a strong sense of school connectedness in turn have a more positive perspective on school in general.

That said, students were also quite quick to point out the implementation issues that have arisen which affect the success of the new role of the teacher in the learning process. One sentiment that was resoundingly clear was that it depended on the teacher. The level of transparency has dramatically increased for both the teacher and the student. With the implementation of the Summit Learning dashboard students, teachers, and parents can see everything, which not only increased communication and understanding of where a student stands, but also opens a window into exactly what a teacher is doing to provide support as well as how timely that support may or may not be. In order for students to be empowered and equipped for their increased role in the learning process, teachers must also be empowered and equipped for their changing role in the learning process. I will explore this further in the implications for practice section of this chapter.

\section{RQ 4: Student Perceptions of their Classmates in the Personalized Learning Initiative}

While the Culture and Climate Survey did not directly address this question, the analysis of interview responses provided insight into this research question. Student responses in terms of their peers showed minimal differences between the more traditional environment and the personalized learning environment. Students spoke more in terms of whether their peer group liked the change or not, as opposed to if it really made a difference in the perception. They highlighted the fact that with increased independence there was limited interaction with peers; however, they also pointed out that the same was true for the whole class instruction that occurred most frequently with the more traditional classroom. 
Students also emphasized that, despite what they had previously shared, they do have more time for small group interaction that enables them to have more in-depth conversations about what they are learning. They have time to talk about what they think, ask questions, and process by having conversations with different people. Interactions with peers were previously about completing an assignment or working on a group project. The difference that students pointed out was the end user benefit of the type of peer interaction as opposed to the interaction itself. The selective code (core value) of implementation issue did not arise in relation to student's perceptions about their peers with the implementation of personalized learning.

\section{Implications for Policy}

As one looks at regulations and policy in the Commonwealth of Kentucky, there are some barriers to full implementation of personalized learning. Seat time, Carnegie units, and testing requirements have a tendency to keep schools in the more traditional educational model. Several policies have paved the way for personalized learning to occur that promote more innovative practices. The new state graduation requirements, performance based credit, early graduation, dual credit, and alternative credit options are five such policies that support a more personalized learning environment.

When educators discuss the importance of authentic learning, deeper learning, competency based education, and student-centered learning, the goal is to move beyond content mastery as a goal of education. Most practitioners agree, but wonder how to execute and bring it to scale, given some of the archaic regulations and policies that remain on the books. The new Commissioner of Education in Kentucky stated recently in a meeting with the Kentucky Innovative Learning Network, "Transforming the student experience is the most important work we can do" (Glass 2020). The Kentucky Innovative Learning Network is a consortium of 
districts aimed at doing just that. This group of districts functions under the direction of the Division of Innovation at the Kentucky Department of Education. One of the charges for this group is to serve as policy change makers in terms of competency education and assessment, a personalized graduation system, and continuation of learning plans through partnerships and collaboration. The vision is to promote student centered learning. At the system level, this requires implementing curriculum planning practices, pedagogy and assessment methods that support a student-centric approach. In the classroom, teachers craft instruction and apply technology in a way the best serves each student's learning journey.

\section{Implications for Practice}

Students indicated the need to address potential implementation issues; most notably, the inconsistencies and differences among teachers throughout the implementation process. This points directly to implications for practice to mitigate these differences and to foster a more inclusive and productive learning environment for all students.

In order to achieve a personalized learning environment and consistency of implementation, leaders should consider teachers first, asking if they have the capacity to effectively plan for and implement instructional practices that promote student-centered learning. These reflections on practice include the concepts of rigor, customization, collaboration, purposefulness, relevance, and classroom community. Leaders also should consider providing continued support for educator growth through purposeful feedback and targeted professional development for adult learners. This feedback and professional development should support teachers in analyzing their practice down to the student task level. What is the task and the work we ask students to complete? Where does the cognitive lift lie within the task? Part of this process should provide teachers concrete ideas and exemplars to help them to see what it looks 
like. Leaders might also highlight practitioners who are doing it well and lift them up so these best practices can be accessible to all students.

The strategies outlined above may help to mitigate the most frequent implementation issue brought forward by the students, "it depends on the teacher". These are the inconsistencies that result affect the equity of a student experience. Ongoing support, coaching, and modeling may be integral to positively affect the student experience and empower students to build agency, self-efficacy, and self-direction.

\section{Implications for Future Research}

Part of the continuous improvement process for schools and districts is continually analyzing programming for its effectiveness in supporting the mission and vision of the system. This is particularly important when addressing innovation in a school system. Best practice calls on leaders to monitor the effectiveness, as well as the costs. Further research focused on conducting cost effectiveness and or cost benefit analyses of the implementation of personalized learning may help schools and districts considering implementing personalized learning to calculate cost and compare outcomes and benefits of this instructional pedagogy.

My study included only one school implementing personalized learning. Future researchers could expanded their analysis to include other districts and schools who have identified personalized learning as an instructional priority. Comparing student perceptions across a broader range of school and district contexts could provide greater insight as to the opportunities afforded to students that may increase their sense of agency, self-efficacy, school connectedness, use of purposeful feedback to improve mastery, and self-directedness that would lead to a more equitable experience for all students. 
An interesting parallel to this work to understand student perceptions of their experience with the implementation of personalized learning is unpacking teacher perceptions of their experience planning, preparing, and implementing practices that foster a student-centered environment. Along with that is gaining insight into the practices of administrators that support teachers to facilitate a non-traditional learning environment that provides opportunities for students to take the driver's seat in the learning process. Further research in this area, may help to mitigate the implementation issues that students brought forward during this study. 


\section{REFERENCES}

Arnot, M., and D. Reay. 2004. The framing of pedagogic encounters: Regulating the social order in classroom learning. In Reading Bernstein, researching Bernstein, ed. J. Muller, B. Davies, and A. Morais, 137-50. London and New York:

RoutledgeFalmer.

Biddulph, M. (2011). Articulating Student Voice And Facilitating Curriculum Agency. Curriculum Journal, 381-399.

Bingham, A. J., Pane, J. F., Steiner, E. D., \& Hamilton, L. S. (2018). Ahead of the Curve: Implementation Challenges in Personalized Learning. Educational Polciy, 454-489.

Bloom, B. S. (1956). Taxonomy of educational objectives. Boston: Allyn and Bacon.

Bray, B. (2015). Personalized Learning. Retrieved from barbarabray.net: http://barbarabray.net/personalized learning

Brown, J., Sorrell, J. H., McClaren, J., \& Creswell, J. W. (2006). Waiting for a liver transplant. Qualitative Health Research, 119-136.

Bruner, J. (1973). Going Beyond the Information Given. New York: Norton.

Casey, K., \& Sturgis, C. (2018). Levers and Logic Models: A Framework to guide research and design high-quality competency-based education systems. Vienna, VA: iNACOL.

Charmaz, K. (1996). The search for Meanings-Grounded Theory. In J. A. Smith, R. Harre, \& L. Van Langenhove (Eds.), Rethinking Methods in Psychology (pp.27-49). London: Sage Publications.

Christensen, C. M., Horn, M. B., \& Staker, H. (2013). Is K-12 Blended Learning Disruptive? An introduction to the theory of hybrids. Boston: Clayton Christensen Institute for Disruptive Innovation. 
Covey, S. R. (2014). The Leader in Me: How schools and parents around the world are inspiring greatness, one child at a time. London: Simon \& Shuster.

Creswell, J. W. (2018). Qualitative Inquiry \& Research Design: Choosing among five approaches. Thousand Oaks: SAGE.

Dee, T., Jacob, B, \& Schwartz, N. (2013). The effects of NCLB on school resources and practices. Educational Evaluation and Policy Analysis, 35(2), 252-279.

Deed, C., Cox, P., Dorman, J., Edwards, D., Farrelly, C., Keeffe, M., .. Y Yager, Z. (2014). Personalized learning in the open classroom: The mutuality of teacher and student agency. International Journal of Pedagogies and Learning, 9(1), 66-75.

Department of Commerce, National Economic Council. (2012). The Competitiveness and Innovative Capacity of the United States. Washington D.C.: U.S.

Denzin, N. K., Lincoln, Y.S. (2011). The SAGE Handbook of Qualitative Research. Sage.

Dixon-Kraus, L. (1996) Vygotsky in the Classroom: Mediated Literacy Instruction. WhitePlains, NY: Longman.

Dweck, C. (2006). Mindset: The New Psychology of Success. Ballantine.

Fielding, M. (2006). Leadership, personalization and high performance schooling: naming the new totalitarianism. School Leadership and Management, 26(4), 347-369.

Fredricks, J. A., Blumenfeld, P. C., \& Paris, A. H. (2004). School engagement: Potential of the concept, state of the evidence. Review of Educational Research, 74(1), 59-109.

Furtak, E., \& Kunter, M. (2012). Effects of autonomy-supportive teaching on student learning and motivation. Journal of Experimental Education, 80(3), 284-316. 
Glass, J. (2020, September 21). KYILN Meeting. Innovation Learning Network. https://education.ky.gov/school/innov/Pages/Innovation-Lab-Network.aspx

Glesne, C. (2016). Becoming Qualitative Researchers: An Introduction. Pearson.

Greene, P. (2019, May 2). Report: Can Personalized Learning Actually Deliver? Retrieved from forbes.com: https://www.forbes.com/sites/petergreene/2019/05/02/report-canpersonalized-learning-actually-deliver/\#411d87f32020

Hagan-Short, M., \& Addison, P. (2019). Competency-based education: Multiple approaches-a single institution. Retrieved from https://doi.org/10.1002/cbe2.1194

Haynes, E., Zeiser, K., Surr, W., Hauser, A., Clymer, L., Walston, J., . . Yang, R. (2016).

Looking Under the Hood of Competency-Based Education: The Relationship Between Competency-Based Education Practices and Students' Learning Skills, Behaviors, and Dispositions. Washington, D.C.: American Institutes for Research.

Ingle, W. K., Greenwell, T., \& Woods, J. (In press, 2020). Commonplace and common language: Kentucky's district mission statements. Journal of Educational Administration.

Johnson, M. (2004). Personalised Learning. New Economy, 11: 224-228. doi:10.1111/j.146841.2004.00370.x

Jukes, I. (2007, June). Understanding digital kids (Dks): Teaching \& learning in the new digital landscape. The Info Savvy Group. Retrieved from https://www.techlearning.com/resources/the-committed-sardine

Kallick, B., \& Zmuda, A. (2016). Students at the Center: Personalized Learning with Habits of Mind. Alexandria: ASCD. 
Kim, T. (2019, July 10). The Messy Reality of Personalized Learning. Retrieved from newyorker.com: https://www.newyorker.com/news/dispatch/the-messy-reality-ofpersonalized-learning

Laughlin, T. (2017). The world has changed, Why haven't our schools? Academy for SocialEmotional Learning in Schools. Retrieved from https://sel.cse.edu/the-world-haschanged-why-havent-our-schools/

Lindgren, R., \& McDaniel, R. (2012). Transforming online learning through narrative and student agency. Educational Technology \& Society, 15(4), 344-355

Martin, J. (2004). Self-regulated learning, social cognitive theory, and agency. Educational Psychologist, 39, 135-145.

Miles, M. B., Huberman, A.M, \& Saldana J. (2014). Qualitative data analysis: A methods sourcebook (3rd ed.). London: SAGE.

Milner, H. R. (2007). Race, Culture, and Researcher Positionality: Working Through Dangers Seen, Unseen, and Unforeseen. Educational Researcher, 388-400.

Morrison, K. A. (2008). Democratic Classrooms: Promises and Challenges of Student Voice and Choice, Part One. Educational Horizons, 57-58.

Morrow, S. L. (2005). Quality and trustworthiness in qualitative research in counseling psychology. Journal of counseling psychology, 52(2), 250.

Murnane, R. J., \& Papay, J. P. (2010). Teachers' views on No Child Left Behind: Support for the principles, concerns about the practices. Journal of Economic Perspectives, 24(3), 151166. 
Nandigam, D., Tirumala, S. S., \& Baghaei, N. (2014). Personalized learning: Current status and potential, 2014 IEEE Conference on e-Learning, e-Management and e-Services (IC3e), Hawthorn, VIC, 2014, pp. 111-116.

National Forum on Education Statistics. (2019). Forum Guide to Personalized Learning Data (NFES2019160). U.S. Department of Education. Washington, DC: National Center for Education Statistics.

Netcoh, S. (2017a). Students' experiences with personalized learning: An examination using selfdetermination theory (Doctoral dissertation). Burlington, VT: University of Vermont.

Netcoh, S. (2017b). Balancing freedom and limitations: A case study of choice provision in a personalized learning class. Teaching and Teacher Education, 66, 383-392.

Patrick, S., Kennedy, K., \& Powell, A. (2013). Mean what you say: Defining and integrating personalized, blended, and competency education. New York: iNACOL.

Pink, D. (2005). A Whole New Mind: Moving from the Information Age to the Conceptual Age. New York: Riverhead books.

Redding, S. (2013). Through the student's eyes: A perspective on personalized learning. Philadelphia, PA: Center on Innovations in Learning. Retrieved from www.centeril.org.

Reeves, T. C., Herrington, J., \& Oliver, R. (2002). Authentic activities and online learning. In A. Goody, J. Herrington, \& M. Northcote (Eds.), Quality conversations: Research and development in higher education, vol. 25 (pp. 562-567).

Saldana, J. (2016). The Coding Manual for Qualitative Researchers (3rd ed.). London: SAGE. 
Senge, P. (2000) Schools that Learn: A Fieldbook for Teachers, Administrators, Parents and Everyone Who Cares about Education (A Fifth Discipline Resource). London: Nicholas Brealey.

Shipps. D. (2006). School reform, corporate style: Chicago, 1880-2000. Lawrence, KS: University Press of Kansas.

Sota, M. S. (2016). Co-designing instruction with students. In M. Murphy, S. Redding, \& J Twyman (Eds.), Handbook on personalized learning for states, districts, and schools (pp. 57-71). Philadelphia, PA: Temple University, Center on Innovations in Learning. Retrieved from www.centeril.org

Stenhouse, L. (1985). Research as a Basis for Teaching: readings. Heinemann.

Sternberg, R. J. and Williams, W. M. (Eds) (1998) Intelligence, Instruction, and Assessment: Theory into Practice. Mahwah, NJ: Lawrence Erlbaum.

Stevens, D. M., Brydon-Miller, M., \& Raider-Roth, M. (2016). Structured Ethical Reflection in Practitioner Inquiry: Theory, Pedagogy, and Practice. The Educational Forum, 80:4, 430-443, DOI: 10.1080/00131725.2016.1206160.

Stone, C. N., Henig, J. R., Jones, B. D., Pierannunzi, C. (2001). Building civic capacity: The politics of reforming urban schools. Lawrence, KS: University Press of Kansas.

Strauss, A., \& Corbin, J. M. (1990). Basics of qualitative research: Grounded theory procedures and techniques. Sage Publications, Inc.

Sturgis, C. \& Casey, K. (2018). Quality principles for competency-based education. Vienna, VA: iNACOL.

Summit Learning. (n.d.) Bring Summit Learning to your school Retrieved from: https://www.summitlearning.org/join-us/program 
Sykes, A., Decker, C., Verbrugge, M. \& Ryan, K. (2014). Personalized learning in progress: Case studies of four Race to the Top district grantee's early implementation. Larium Evaluation Group, on behalf of United States Department of Education. https://rttd.grads360.org/services/PDCService.svc/GetPDCDocumentFile?fileId=7452 Taylor, L. \& Parsons, J. (2011). Improving Student Engagement. Current Issues in Education, 14(1). Retrieved from http://cie.asu.edu/

The New Teacher Network. (2018). The opportunity myth: What students can show us about how school is letting them down- and how to fix it. New York: TNTP.

The SHARE Team. (2020). The Invisible Backpack: Hidden Causes of Challenging Student Behaviors. Retrieved from https://blog.sharetolearn.com/leaders-link/the-invisible-backpack/

Trow, M. (1999). From Mass Higher Education to Universal Access: The American Advantage. Minerva: A Review of Science, Learning \& Policy, 37(4), 303-328. Retrieved from https://search-ebscohost-com.echo.louisville.edu/login.aspx ?direct= true $\& d b=$ a9h\&AN=11306673\&site=ehost-live

Verna, J. R. (2007). Effective Parental Influence: Academic home climate linked to children's achievement. Educational Research and Evaluation An International Journal on Theory and Practice, 501-519.

Waldrip, B., Cox, P., Deed, C., Dorman, J., Edwards, D., Farrelly, C., . . Yager, Z. (2014). Student perceptions of personalised learning: Development and validation of a questionnaire with regional secondary students. Learning Environments Research: An International Journal, 17(3), 355-370. doi:10.1007/s10984-014-9163-0 
Wolf, M. A. (November, 2010). Innovate to educate: System (re)design for personalized learning: A report from the 2010 symposium. Software \& Information Industry Association: Washinton D.C.

Wolters, C., \& Pintrich, P. (1998). Contextual differences in student motivation and self-regulated learning in mathematics, English, and social studies classrooms. Instructional Science: An International Journal of Learning and Cognition, 26(1-2), 27-47. doi:10.1023/A:1003035929216

Woo, Y., \& Reeves, T. (2007). Meaningful interaction in web-based learning: A social constructivist interpretation. Internet \& Higher Education, 10(1).

World Economic Forum. (2016). The future of jobs employment, skills and workforce strategy for the fourth industrial revolution. Geneva, Switzerland: Author.

Yin, R.K. (2018). Case Study Research and Applications: Design and Methods. Los Angeles:Sage

Zeiser, K., Scholz, C., \& Cirks, V. (2018). Maximizing student agency: Implementing and measuring student-centered learning practices. Boston: American Insitute for Research 


\section{APPENDIX A: SURVEY}

Which four of the following words or phrases best describe, in general, the expectations for you as a student at your school?

*Pick 4 answers

I am learning.

I am busy.

I understand.

I know.

I am able to explain.

I am able to memorize.

I should find it myself.

I should ask a teacher.

I am expected to be good at everything.

I am expected to be good at some things.

Which four of the following phrases best describe, in general, the kinds of things your teachers say to you while at school?

*Pick 4 answers

What are you doing?

What are you thinking?

We will be working on...

You will be working on...

You are learning...

You are being taught...

Explain it.

Repeat it.

You should do it this way.

You could do it this way.

You got it right!

You took the right approach.

I'm interested in your answer.

I'm interested in your approach.

Which four of the following words or phrases best describe, in general, how you feel when trying to complete your assignments while at school?

*Pick 4 answers

Rushed

Hectic

Calm

Hurried

Deliberate

Pressured 
Patient

Never enough time

Usually enough time

Relaxed

Tense

Which four of the following words best describe, in general, what you think of your teachers?

*Pick 4 answers

Real

Honest

Fun

Interesting

Inconsistent

Consistent

Caring

Active

Lazy

Curious

Uninterested

Mean

Fake

Unfair

Untrustworthy

Which four of the following words or phrases best describe, in general, the things you most often DO while in class at school?

*Pick 4 answers

Listen to teachers

Complete brief projects

Complete long projects

Write

Think

Memorize

Complete worksheets

Work with others

Work alone

Complete challenging work

Complete easy work

Make presentations

Write papers

Take tests

Give project demonstrations

Which four of the following words or phrases best describe, in general, your experiences in your classes? 
*Pick 4 answers

Consistent

Random

Orderly

Rowdy

Rushed

Calm

Normal

Weird

Positive interactions with others

Negative interactions with others

Working in groups

Working alone

Challenging

Easy

New ideas encouraged

Correct answers encouraged

Which four of the following words best describe, in general, the interactions you have with adults at your school?

*Pick 4 answers

Important

Brief

Trusting

Respectful

Supportive

Helpful

Useless

Distant

Relaxed

Tense

Which four of the following words best describe the physical spaces in which you spend most of your time at school?

*Pick 4 answers

Bright

Unique

Stressful

Flexible

Inviting

Plain

Chaotic

Stable

Comfortable 
Open

Closed

Neglected

Which four of the following words best describe, in general, how you feel while at school?

*Pick 4 answers

Happy

Angry

Challenged

Bored

Interested

Afraid

Appreciated

Pressured

Encouraged

Confused

Excited

Lonely

Supported

Tired 


\section{APPENDIX B: INTERVIEW QUESTIONS}

1. What are your thoughts about school and yourself as a learner? (RQ 1)

2. Describe what your school day looks like with personalized learning. (RQ 1)

3. Describe what you do as a student. (RQ 2)

4. How does that compare to previous school experience? (RQ 2)

5. Describe your interactions with teachers. (RQ 3)

6. Describe what your teachers do (RQ 3)

7. How does that compare to previous school experience? (RQ 3)

8. Describe your interactions with other students. (RQ 4)

9. How does that compare to previous school experience? (RQ 4)

10. How do you know if you are "getting it" or not? (RQ 2)

11. What are your responsibilities in the learning process compared to your teachers? (RQ 2)

12. How does that compare to previous school experience? (RQ 2) 


\section{APPENDIX C: STUDENT INFORMED ASSENT \\ STUDENT PERCEPTIONS OF PERSONALIZED LEARNING IN A RURAL SCHOOL DISTRICT}

\section{Student Assent Form}

My name is Kathy House; I am working under the direction of Prof. William Ingle, in the College of Education at the University of Louisville. I am a doctoral student at the University of Louisville. I am inviting you to participate in a research study about personalized learning. Your parent(s) know we are talking with you about the study. This form will tell you about the study to help you decide whether you want to take part in it.

\section{What am I being asked to do?}

If you agree to participate in the study, I will ask you to participate in an individual interview in which I will ask you to respond verbally to 12 questions about your perceptions of personalized learning. I will audio record the interview in order to conduct an analysis of all interviewee responses later.

\section{What are the benefits to me for taking part in the study?}

Taking part in this study may not have direct benefits to you, but it will help me understand the importance of student agency, voice, and choice in your experience as a student. Your participation may inform improvements in the design and delivery of personalized learning for future students in this district and elsewhere.

\section{Can anything bad happen if $I$ am in this study?}

I do not expect anything bad happening to you but some kids might have anxiety about being interviewed. I want to assure you that there are no right or wrong answers. I will offer the opportunity for interviewees to read the transcript of their interview to ensure transparency and integrity.

\section{Who will know that I am in the study?}

If you decide to be in the study, I will not tell anyone else how you respond or act as part of the study. Even if your parents or teachers ask, I will not tell them about what you say or do in the study.

\section{Do I have to be in the study?}

No, you do not. The choice is yours. No one will get angry or upset if you do not want to do this. You can change your mind anytime if you decide you do not want to be in the study anymore.

\section{What if I have questions?}

If you have questions about the study, you can ask me now or anytime during the study. You can also call me at (502)255-3201 ext. 1013 or e-mail me at Kathy.house@ trimble.kyschools.us. You may also contact Dr. William Ingle by phone at (502) 852-6097 or email at william.ingle@louisville.edu. 
If you have any questions about your rights as a participant in this research or if you feel you have been placed at risk, you can contact the IRB Office at University of Louisville (502)8525188 or by email: hsppofc@louisville.edu. You will receive a copy of this form for your records.

Signing below means that you have read this form and that you are willing to be in this study:

Name of the Participant (Printed)

Printed Name of Person Explaining Consent Form

Printed Name of Investigator (PI, Sub-I, or Co-I) Date
Signature of the Participant Date

Signature of Person Explaining Date Signed Consent Form (if other than the Investigator)

Signature of Investigator (PI, Sub-I, or Co-I) 


\title{
APPENDIX D: PARENT/GUARDIAN INFORMED CONSENT \\ STUDENT PERCEPTIONS OF PERSONALIZED LEARNING IN \\ A RURAL SCHOOL DISTRICT
}

\begin{abstract}
Parental Consent
INVITATION TO PARTICIPATE:

Dear Parent, My name is Kathy House; I am working under the direction of Prof. William Ingle, in the College of Education at the University of Louisville. I am a doctoral student at the University of Louisville. I am conducting a research study about personalized learning. The purpose of this form is to provide you with information that will help you decide if you will give consent for your child to participate in this research.
\end{abstract}

\section{KEY INFORMATION ABOUT THIS RESEARCH STUDY:}

The following is a short summary of this study to help you decide whether you want your child to be a part of this study. The purpose of this study is understand student perceptions of the implementation of personalized learning at their school. Your child will be asked to answer 12 questions during an interview. I expect that your child will be in this research study for only the time of the interview. I do not anticipate any risks to your child, but some kids might have anxiety about being interviewed. I want to assure you that there are no right or wrong answers. I will offer the opportunity for interviewees to read the transcript of their interview to ensure transparency and integrity.

\section{STUDY PURPOSE:}

The purpose of this study is to understand student perceptions of the role of the teacher and their peers, in addition to their role as a learner. It is also to understand how student voice and choice support student engagement in the learning process.

\section{NUMBER OF PARTICIPANTS:}

If you agree to participate, your child will be one of 15 participants who will be participating in this research.

\section{PROCEDURES FOR THE STUDY:}

If you agree for your child to participate in the study, she or he will participate in an individual interview in which I will ask your child to respond verbally to 12 questions about their perceptions of personalized learning. I will audio record the interview in order to conduct an analysis of all interviewee responses later. The interview will take place at school in the conference room and should take approximately 30-45 minutes, depending on how detailed your child's responses are.

\section{RISKS AND INCONVENIENCES:}

There are minimal risks and inconveniences to participating in this study. These include: The child may be uncomfortable answering the interview questions and the time the child spends for participating in the study might be considered inconvenience. 


\section{SAFEGUARDS:}

To minimize these risks and inconveniences, the following measures will be taken: The child can skip any questions that he or she feels uncomfortable answering during the interview. The child may skip any activity as part of the research and/or intervention. The interviews may be scheduled at a time that is convenient to the child and at a place that is private.

\section{CONFIDENTIALITY:}

Total privacy cannot be guaranteed. We will protect your child's privacy to the extent permitted by law. If the results from this study are published, your child's name will not be made public.

Once your information leaves our institution, we cannot promise that others will keep it private.

Your child's information may be shared with the following:

- The sponsor and others hired by the sponsor to oversee the research

- The University of Louisville Institutional Review Board, Human Subjects Protection Program Office, Privacy Office, others involved in research administration and research and legal compliance at the University, and others contracted by the University for ensuring human participants safety or research and legal compliance

- The local research team

- Researchers at other sites participating in the study

- People who are responsible for research, compliance and HIPAA/privacy oversight at the institutions where the research is conducted

- Applicable government agencies, such as:

○ Office for Human Research Protections

\section{VOLUNTARY PARTICIPATION:}

Your child's participation in this study is voluntary. Your child may decline participation at any time. You may also withdraw your child from the study at any time; there will be no penalty. It will not affect your child's grade, treatment/care, etc. Likewise, if your child chooses not to participate or to withdraw from the study at any time, there will be no penalty.

\section{BENEFITS OF TAKING PART IN THE STUDY:}

Although there may be no direct benefit to your child, the possible benefit of your child's participation is to help the school(s) and teachers to engage in reflection of student perceptions to guide the design and implementation of personalized learning.

\section{ALTERNATIVES:}

Since participation in this study is voluntary, the alternative to participating is to choose not to participate.

\section{U.S. Department of Education (DOE) Funded Studies}

Because or this school system receives funding from the DOE, we are required to tell you the following information. 
The information we collect from the education or study records of you or your child may only be used to meet the purposes of the study as stated in this consent. We will conduct this study in a manner that does not allow identification of you or your child by anyone other than study team members or others who may have a legitimate reason to know. All instructional materials or survey instruments used for the research, including teachers' manuals, films, tapes, or other supplementary instructional material used in connection with this study, are available for you to see before the study begins if you ask to see it. If you want to see any of this information, please contact Kathy House, (502)255-3201 and they will give you a date and time where it will be available for you to review. Once we have completed this study, we are required by the U.S. Department of Education to destroy or return to the school system all personally identifiable information when no longer needed for the purposes of the study. We expect this study to last for no more than one year, and we will destroy or return the information to the school system by July 1, 2021.

\section{CONTACT INFORMATION:}

If you have questions about the study, you can ask me now or anytime during the study. You can also call me at (502)255-3201 ext. 1013 or e-mail me Kathy.house@trimble.kyschools.us. You may also contact Dr. William Ingle by phone at (502) 852-6097 or email william.ingle@louisville.edu.

If you have any questions about your rights as a participant in this research or if you feel you have been placed at risk, you can contact the IRB Office at University of Louisville (502)8525188 or by email: hsppofc@louisville.edu. You will receive a copy of this form for your records.

\section{Acknowledgment and Signatures}

This document tells you what will happen during the study if you choose to take part. Your signature and date indicates that this study has been explained to you, that your questions have been answered, and that you agree to take part in the study. You are not giving up any legal rights to which you are entitled by signing this informed consent document though you are providing your authorization as outlined in this informed consent document. You will be given a copy of this consent form to keep for your records.

\begin{tabular}{l} 
Participant Name (Please Print) \\
- \\
\hline
\end{tabular}

Parent/Guardian Name (Please Print)

$\overline{\text { Printed Name of Person Explaining Consent Form }}$

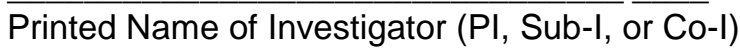

Signature of Parent Date Signed

Signature of Person Explaining Date Signed
Consent Form (if other than the Investigator)

$\overline{\text { Signature of Investigator (PI, Sub-I, or Co-I) Dat }}$ 


\section{APPENDIX E: STRUCTURED ETHICAL REFLECTION}

\begin{tabular}{|c|c|c|c|c|c|c|c|c|}
\hline Values & $\begin{array}{c}\text { Developing } \\
\text { Partnerships }\end{array}$ & $\begin{array}{l}\text { Constructin } \\
\text { g Research } \\
\text { Question }\end{array}$ & $\begin{array}{c}\text { Planning } \\
\text { Project/ } \\
\text { Action }\end{array}$ & $\begin{array}{c}\text { Recruiting } \\
\text { Participants }\end{array}$ & $\begin{array}{c}\text { Collecting } \\
\text { Data/ Taking } \\
\text { Action }\end{array}$ & $\begin{array}{l}\text { Analyzing } \\
\text { Data/ } \\
\text { Evaluating } \\
\text { Action }\end{array}$ & $\begin{array}{l}\text { Member } \\
\text { Checking }\end{array}$ & $\begin{array}{c}\text { Going Public } \\
\text { (Presentation \& } \\
\text { Publication) }\end{array}$ \\
\hline Trust & $\begin{array}{l}\text { Considering } \\
\text { the } \\
\text { viewpoints of } \\
\text { others }\end{array}$ & $\begin{array}{l}\text { Developing } \\
\text { open-ended } \\
\text { questions that } \\
\text { do not } \\
\text { demonstrate } \\
\text { bias. }\end{array}$ & $\begin{array}{l}\text { Clearly } \\
\text { stating } \\
\text { purpose of } \\
\text { project and } \\
\text { following } \\
\text { through with } \\
\text { plans. }\end{array}$ & $\begin{array}{l}\text { Explaining } \\
\text { the purpose } \\
\text { of } \\
\text { participation } \\
\text { and how the } \\
\text { information } \\
\text { gathered will } \\
\text { be used. }\end{array}$ & $\begin{array}{l}\text { Staying true to } \\
\text { the words and } \\
\text { responses of } \\
\text { participants. }\end{array}$ & $\begin{array}{l}\text { Ensuring that } \\
\text { the data is the } \\
\text { foundation of } \\
\text { action. }\end{array}$ & $\begin{array}{l}\text { Offering the } \\
\text { opportunity for } \\
\text { interviewees to } \\
\text { review the } \\
\text { transcript of } \\
\text { their interview }\end{array}$ & $\begin{array}{l}\text { Accurately } \\
\text { representing the } \\
\text { voices heard } \\
\text { through } \\
\text { interviews. }\end{array}$ \\
\hline Equality & $\begin{array}{l}\text { Ensuring } \\
\text { buy-in, } \\
\text { ownership, } \\
\text { and voice of } \\
\text { participants } \\
\text { and partners. }\end{array}$ & $\begin{array}{l}\text { Developing } \\
\text { questions that } \\
\text { honor the } \\
\text { perspectives } \\
\text { of the } \\
\text { interviewees. }\end{array}$ & $\begin{array}{l}\text { Ensuring a } \\
\text { cross section } \\
\text { of } \\
\text { participants } \\
\text { so all voices } \\
\text { and } \\
\text { perspectives } \\
\text { are } \\
\text { represented }\end{array}$ & $\begin{array}{l}\text { Ensuring } \\
\text { randomizatio } \\
\mathrm{n} \text { of selection } \\
\text { and clearly } \\
\text { articulating } \\
\text { the process to } \\
\text { potential } \\
\text { participants. }\end{array}$ & $\begin{array}{l}\text { Being mindful } \\
\text { of body } \\
\text { language and } \\
\text { responses during } \\
\text { the interview to } \\
\text { demonstrate } \\
\text { impartiality. }\end{array}$ & $\begin{array}{l}\text { Gathering a } \\
\text { broad range of } \\
\text { data that } \\
\text { values a } \\
\text { variety of } \\
\text { perspectives. }\end{array}$ & $\begin{array}{l}\text { Remaining } \\
\text { true to the } \\
\text { foundational } \\
\text { questions, so } \\
\text { all } \\
\text { interviewees } \\
\text { have a similar } \\
\text { experience. }\end{array}$ & $\begin{array}{l}\text { Communicating } \\
\text { the process, } \\
\text { recruitment of } \\
\text { participants to } \\
\text { demonstrate the } \\
\text { randomization } \\
\text { of participant } \\
\text { selection to } \\
\text { reflect multiple } \\
\text { perspectives. }\end{array}$ \\
\hline $\begin{array}{l}\text { Open } \\
\text { mindedness }\end{array}$ & $\begin{array}{l}\text { Being open } \\
\text { and reflective } \\
\text { about the } \\
\text { perceptions } \\
\text { of others that } \\
\text { are different } \\
\text { from my } \\
\text { own. }\end{array}$ & $\begin{array}{l}\text { Understandin } \\
\mathrm{g} \text { that } \\
\text { research } \\
\text { questions } \\
\text { may be } \\
\text { iterative and } \\
\text { to maintain a } \\
\text { growth } \\
\text { mindset with } \\
\text { the process. }\end{array}$ & $\begin{array}{l}\text { Respecting } \\
\text { the } \\
\text { knowledge } \\
\text { and } \\
\text { experience, } \\
\text { others bring } \\
\text { to the } \\
\text { research } \\
\text { process. }\end{array}$ & $\begin{array}{l}\text { Representing } \\
\text { clearly that I } \\
\text { am looking } \\
\text { for all } \\
\text { perspectives } \\
\text { and not } \\
\text { looking for a } \\
\text { specific } \\
\text { response. }\end{array}$ & $\begin{array}{l}\text { Listening to } \\
\text { understand the } \\
\text { answers to the } \\
\text { interview } \\
\text { questions. }\end{array}$ & $\begin{array}{l}\text { Suspending } \\
\text { judgment and } \\
\text { be mindful of } \\
\text { all points of } \\
\text { view. }\end{array}$ & $\begin{array}{l}\text { Listening to } \\
\text { feedback from } \\
\text { participants } \\
\text { about the } \\
\text { process. }\end{array}$ & $\begin{array}{l}\text { Being mindful } \\
\text { that stakeholders } \\
\text { will have } \\
\text { varying } \\
\text { perceptions of } \\
\text { the data }\end{array}$ \\
\hline Adaptability & $\begin{array}{l}\text { Having the } \\
\text { ability to be } \\
\text { iterative in } \\
\text { the process } \\
\text { of } \\
\text { relationship } \\
\text { building }\end{array}$ & $\begin{array}{l}\text { Creating } \\
\text { questions } \\
\text { with the } \\
\text { interviewee } \\
\text { in mind }\end{array}$ & $\begin{array}{l}\text { Making } \\
\text { choices in } \\
\text { actions that } \\
\text { meet the } \\
\text { needs of the } \\
\text { students and } \\
\text { do not } \\
\text { interfere with } \\
\text { their access } \\
\text { and } \\
\text { instructional } \\
\text { time. }\end{array}$ & $\begin{array}{l}\text { Remaining } \\
\text { flexible in } \\
\text { meeting the } \\
\text { needs of the } \\
\text { participants } \\
\text { throughout } \\
\text { the collection } \\
\text { of data from } \\
\text { interviews. }\end{array}$ & $\begin{array}{l}\text { Ensuring that } \\
\text { throughout the } \\
\text { interview } \\
\text { process, I listen, } \\
\text { acknowledge } \\
\text { and document } \\
\text { the words of the } \\
\text { interviewees } \\
\text { posing follow up } \\
\text { questions to gain } \\
\text { a clear insight } \\
\text { into their } \\
\text { experience. }\end{array}$ & $\begin{array}{l}\text { Following } \\
\text { what the data } \\
\text { says and not } \\
\text { finding data } \\
\text { that supports a } \\
\text { specific } \\
\text { answer. }\end{array}$ & $\begin{array}{l}\text { Meeting } \\
\text { individual } \\
\text { participant } \\
\text { needs in the } \\
\text { member } \\
\text { checking } \\
\text { process. }\end{array}$ & $\begin{array}{l}\text { Being mindful } \\
\text { of the needs of } \\
\text { stakeholders and } \\
\text { other audience } \\
\text { members. }\end{array}$ \\
\hline Respect & $\begin{array}{l}\text { Including } \\
\text { input from } \\
\text { partnerships }\end{array}$ & $\begin{array}{l}\text { Creating } \\
\text { questions that } \\
\text { are open and } \\
\text { provide } \\
\text { benefit to the } \\
\text { respondent. }\end{array}$ & $\begin{array}{l}\text { Being } \\
\text { mindful of } \\
\text { the time I am } \\
\text { asking of } \\
\text { others }\end{array}$ & $\begin{array}{l}\text { Including a } \\
\text { variety of } \\
\text { participants } \\
\text { and being } \\
\text { clear that my } \\
\text { purpose is to } \\
\text { listen to their } \\
\text { perceptions. }\end{array}$ & $\begin{array}{l}\text { Scheduling } \\
\text { interviews that } \\
\text { takes into } \\
\text { account the time } \\
\text { of interviewees }\end{array}$ & $\begin{array}{l}\text { Adhering to } \\
\text { the viewpoints } \\
\text { of participants. }\end{array}$ & $\begin{array}{l}\text { Making any } \\
\text { necessary } \\
\text { changes to the } \\
\text { transcript after } \\
\text { interviewee } \\
\text { reviews. }\end{array}$ & $\begin{array}{l}\text { Communicating } \\
\text { with participants } \\
\text { regarding how } \\
\text { their } \\
\text { perspectives will } \\
\text { be represented. }\end{array}$ \\
\hline Transparency & $\begin{array}{l}\text { Being clear } \\
\text { about the } \\
\text { purpose of } \\
\text { the work }\end{array}$ & $\begin{array}{l}\text { Providing } \\
\text { clarity of } \\
\text { purpose } \\
\text { behind the } \\
\text { questions. }\end{array}$ & $\begin{array}{l}\text { Communicati } \\
\text { ng in a clear } \\
\text { concise } \\
\text { manner and } \\
\text { answering all } \\
\text { questions. }\end{array}$ & $\begin{array}{l}\text { Being clear } \\
\text { about the } \\
\text { purpose, } \\
\text { process, and } \\
\text { product. }\end{array}$ & $\begin{array}{l}\text { Communicating } \\
\text { the type of data I } \\
\text { am collecting, } \\
\text { the purpose } \\
\text { behind the } \\
\text { collection of that } \\
\text { data, and how it } \\
\text { will be used. }\end{array}$ & $\begin{array}{l}\text { Accurately } \\
\text { documenting } \\
\text { and } \\
\text { representing } \\
\text { what } \\
\text { interviewees } \\
\text { state }\end{array}$ & $\begin{array}{l}\text { Clearly } \\
\text { communicatin } \\
\mathrm{g} \text { the process. }\end{array}$ & $\begin{array}{l}\text { Communicating } \\
\text { the purpose, } \\
\text { process and } \\
\text { product. }\end{array}$ \\
\hline Integrity & $\begin{array}{l}\text { Following } \\
\text { through } \\
\text { agreed upon } \\
\text { actions }\end{array}$ & $\begin{array}{l}\text { Ensuring that } \\
\text { research } \\
\text { questions are } \\
\text { open ended } \\
\text { and not } \\
\text { directive. }\end{array}$ & $\begin{array}{l}\text { Acting in a } \\
\text { manner } \\
\text { throughout } \\
\text { the project } \\
\text { that stays } \\
\text { true to the } \\
\text { purpose. }\end{array}$ & $\begin{array}{l}\text { Being clear } \\
\text { about the } \\
\text { purpose } \\
\text { through the } \\
\text { recruiting } \\
\text { process. }\end{array}$ & $\begin{array}{l}\text { Following } \\
\text { through with } \\
\text { agreed upon } \\
\text { actions during } \\
\text { the interview } \\
\text { process. }\end{array}$ & $\begin{array}{l}\text { Accurately } \\
\text { documenting } \\
\text { and } \\
\text { representing } \\
\text { what } \\
\text { interviewees } \\
\text { state } \\
\end{array}$ & & $\begin{array}{l}\text { Remaining true } \\
\text { to the plan and } \\
\text { the research. }\end{array}$ \\
\hline
\end{tabular}




\section{APPENDIX F: STRATEGIC PLAN/GRADUATE PROFILE}

\begin{tabular}{|c|c|c|}
\hline \multicolumn{3}{|c|}{ Trimble County Schools Strategic Plan 2017-2020 } \\
\hline Achieve Excellence In Academics & Achieve Excellence In Leadership & xcellence In Resource Utilization \\
\hline $\begin{array}{l}\text { Students who earn a diploma } \\
\text { from Trimble County Schools } \\
\text { will be: self-motivated, resilient } \\
\text { and persevere through } \\
\text { challenges, confident, } \\
\text { innovative problem solvers, } \\
\text { critical thinkers, effective } \\
\text { communicators, goal-driven, } \\
\text { leaders who are ready for post- } \\
\text { secondary education/ careers, and } \\
\text { service oriented citizens. }\end{array}$ & $\begin{array}{l}\text { As leaders we will demonstrate } \\
\text { excellence through: fidelity and } \\
\text { commitment to our mission and } \\
\text { vision, effective governance, ability } \\
\text { to engage stakeholders in meaningful } \\
\text { ways, the capacity to improve the } \\
\text { experience of the learner and } \\
\text { educator. }\end{array}$ & $\begin{array}{l}\text { We will utilize our resources in an } \\
\text { equitable manner so the needs of all } \\
\text { learners are effectively addressed } \\
\text { while supporting staff to maximize } \\
\text { student learning through } \\
\text { streamlined operational procedures } \\
\text { and organizational effectiveness. }\end{array}$ \\
\hline \multicolumn{3}{|c|}{$\begin{array}{c}\text { What will that look } \\
\text { like? }\end{array}$} \\
\hline
\end{tabular}


- All students will have the opportunity for personalized learning

- Classroom communities will be student centered

- All students will have opportunities to engage in academic dialogue to make meaning, determine importance, and increase understanding.

- All students will have collaborative opportunities (project based learning) that will foster creativity and develop problem solving skills in real-world situations.

- All students will have a go-to adult (mentor) to set personal and academic goals with on a weekly basis.

- All students will monitor their own learning through the use of rubrics and exemplars to review and revise their work.

- Teachers will provide targeted instruction and specific feedback based on relevant student data to support students' academic growth.

- Staff and student's actions, language, and behaviors will demonstrate a growth mindset.

- Staff will focus on recognizing and reinforcing appropriate behaviors through implementation of PBIS strategies.

- Through community partnerships, students will engage in service projects to enhance and embrace their larger community.
- Parents will have opportunities to be active partners in the school community.

- District leadership will model high standards in accordance with state and local policies, procedures, and code of ethics.

- District leadership will conduct surveys and analyze the effectiveness of our governance for continuous improvement.

- District leadership will conduct surveys to gather feedback from stakeholders and will set goals to improve community relationships.

- District leadership will systematically refine evaluation practices that support building capacity of educators.

- District leadership will support professional practice of teachers through targeted monthly walkthroughs, specific feedback, professional learning cohorts, and instructional updates.
- Staff new to the district will participate in an induction program and will be assigned a mentor.

- Trimble County Schools will be represented at job fairs to recruit and promote our district.

- Trimble County Schools will actively participate in regional partnerships and professional learning opportunities.

- Professional learning will be personalized for certified personnel.

- PLC structures and processes at each building will enhance teacher collaboration and promote analysis of student data.

- A systematic process will be utilized to support the achievement of a balanced budget that reflects district needs.

- Systems, procedures, and expectations will be specifically defined and communicated through an Operations Manual and Employee Handbook. 


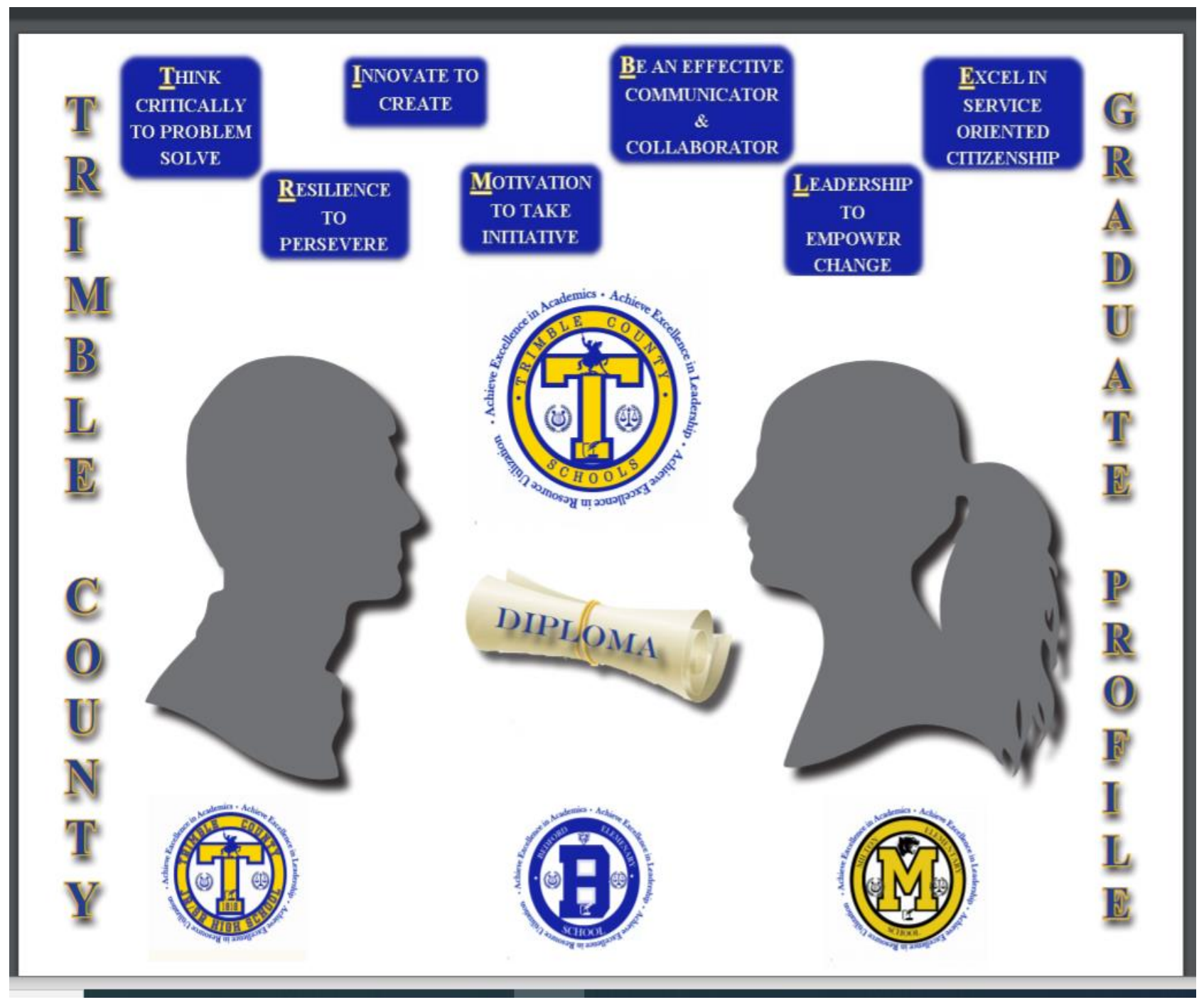


APPENDIX G: Walkthrough Documents

Teacher:

Date:

Class Period:

Supportive Learning Environment that provides social/emotional support: Students demonstrate a positive attitude about the classroom and learning, take risks in learning (without fear of negative feedback), are provided support and assistance to understand content and accomplish tasks, are provided additional/alternative instruction and feedback at the appropriate level of challenge for her/his needs.

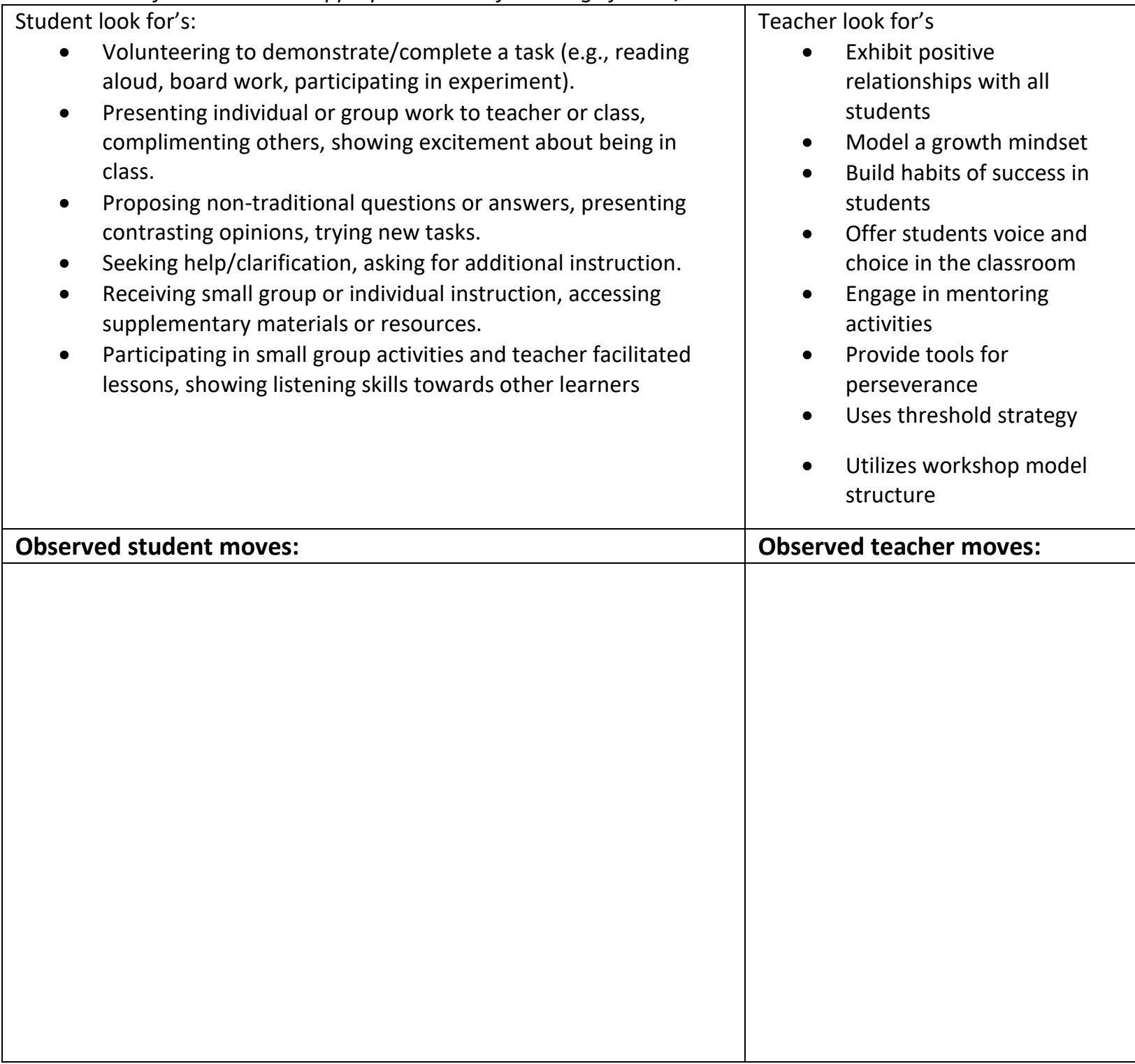


Teacher:

Date:

Class Period/Time:

The Equitable Learning Environment-demonstrating beliefs about learning: Students have customized learning opportunities (appropriate challenge, additional supports for defined learning needs), students have equitable access to grade level materials, equal access to classroom discussions, activities, resources, technology, and support; rules and consequences are fair, clear, and consistently applied, and ongoing opportunities to learn about their own and other's background, cultures, \& differences

Student look for's:

- Demonstrating knowledge through multiple modalities: using visuals, hands-on activities, auditory cues

- Acting as group leader, note taker, timekeeper or presenter; moving freely from learning centers, groups; using resources

- Self-correcting, thinking about thinking, showing acceptance of rules

- Sharing how content relates from their perspectives, making statements or asking questions about peers' backgrounds, working in groups with students from other backgrounds

- Using the language of a growth mindset
Teacher look for's

- Demonstrating flexibility and responsiveness

- $\quad$ Meet students where they are (ZPD)

- Builds on prior knowledge

- Working with individual or small groups of students

- Use anchor charts to communicate expectations to provide purpose and relevance

- Use anchor charts to communicate learning targets/essential questions/learning path

- Models expectations

- Utilizes PBIS

- Instilling the "Power of Yet" to foster a growth mindset

Observed student moves:

Observed teacher moves: 
Teacher:

Date:

Class Period:

D/E- Progress Monitoring \& Feedback (personalized learning) Environment: Student is asked and/or quizzed about individual progress/learning, responds to teacher feedback to improve understanding, demonstrates or verbalizes understanding of the lesson/content, understands how her/his work is assessed, has opportunities to revise/improve work based on feedback, and is actively engaged in the learning activities.

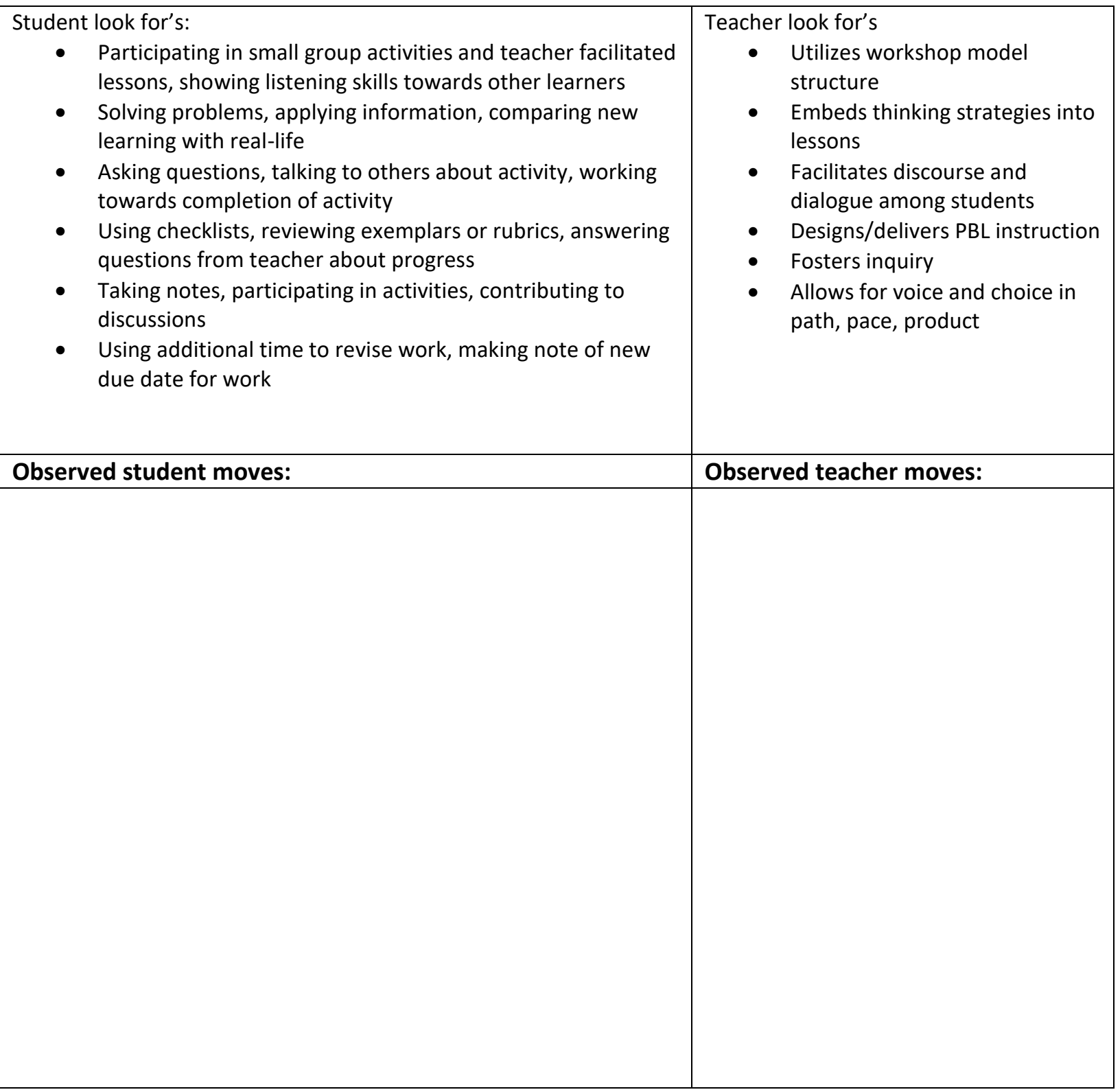




\title{
Kathryn Merges House
}

\author{
Louisville, KY 40204 | $\underline{\text { 502-558-2259 }}$ | Kathy.house@ trimble.kyschools.us
}

\section{PROFESSIONAL SUMMARY}

Strategic, innovative, and enthusiastic leader with strong communication skills and a collaborative leadership style that fosters inclusion of stakeholders in the continuous improvement process. Goal driven leader who develops cohesion to insure decisions are in alignment with the purpose, mission/vision of the organization.

\section{EDUCATION \& CERTIFICATIONS}

Doctor of Education, University of Louisville

Dec 2020

Education Leadership and Organizational Development

Superintendent Certification

May 2020

Educational Specialist Degree, University of Louisville

2012

K-12 Principal/Supervisor of Instruction Certification Aspiring Principals Academy

$\begin{array}{ll}\text { National Board Certification, NBCT } & 2003\end{array}$

Master of Science in Special Education, Indiana State University 2000

Focus on K-12 Learning Disabilities

$\begin{array}{ll}\text { Bachelor's degree, Indiana University } & 1987\end{array}$

Focus on Special Education

\section{PROFESSIONAL EXPERIENCE}

\section{Chief Academic Officer/ Personnel Director Trimble County Schools}

July 2016 - Present

Trimble County Schools - Bedford, KY

- Assessed and evaluated the status of curriculum and instructional programs and services to maintain high-quality performance objectives and standards. Facilitated the districts preparation for and successful attainment of Advanc-Ed District Accreditation.

- Researched and incorporated new educational trends and instructional best practices to optimize education effectiveness. Led innovative district initiatives that resulted in selection of the district as a member of the Kentucky Competency Education and Assessment Consortium and the Kentucky Innovative Learning Network. 
- Defined and enforced student academic achievement standards to align with district goals and objectives. Facilitated the development of standards aligned unit plans created in partnership with teachers to serve as pacing guides and curriculum maps for new state standards.

- Established instructional practices driven through statistical performance data. Refined and implemented PLC structures district-wide. Developed and instituted a district walkthrough process to provide qualitative data to support improvement of teaching and learning. Established an electronic data wall system to insure that data analysis was used to drive instruction. The middles school came out of TSI status after one year as a result of this work.

- Managed all personnel actions from hiring through staff development and support. Streamlined the HR department and initiated the use of online tools for recruit/hire/records, time clock for payroll, and online sub system.

- Facilitated continued education for teaching staff through implementation of quality curriculum training and appropriation of necessary resources. Alignment of strategic plan and CSIP/CDIP to professional learning plan.

- Trained teachers on effective teaching techniques, classroom management strategies and behavior modification.

Mentored newly hired educators and provided encouragement and feedback. Developed and facilitated job embedded coaching cycles in partnership with building principals and facilitated professional learning cohorts for certified staff.

\section{Principal Zoneton Middle school 2014-2016}

Bullitt County Schools - Shepherdsville, KY

- Monitored and evaluated educational programs to maintain high-quality performance objectives and standards. Increased student performance resulted in the school designation moving from "Needs Improvement" to "Proficient".

- Modeled expected and appropriate leadership to promote teaching staff and administrative personnel's positive interaction with students and families. Increased participation of stakeholders in school events.

- Performed classroom evaluations to assess teacher strategies and effectiveness.

- Developed subject and grade leaders to advance oversight and improve instruction.

- Established positive, stimulating learning environment for students and learner-focused setting for teachers. \#ZonetonStrong- exhibiting strength in character, community, and academics became who we were as a school and how we went about business. It still exists today.

- Trained teachers on effective teaching techniques, classroom management strategies and behavior modification. Implementation of PBIS reduced discipline referrals by $45 \%$.

Associate Principal,

$06 / 2010$ to $02 / 2014$

South Oldham Middle School - Crestwood, KY

Literacy Coach,

$05 / 2006$ to $06 / 2010$

South Oldham Middle School - Crestwood, KY

Special Education Teacher,

08/2001 to $05 / 2006$

South Oldham Middle School - Crestwood, KY 


\section{PROFESSIONAL AFFILIATIONS}

\section{Cognia (Advanc-Ed) 2016-present}

Maintain communication with other agencies and school districts to share and receive information on effective programs and practices. Assimilate and evaluate evidence regarding the status of curriculum and instruction programs and services including assessment and evaluation.

- Accreditation review teams- seven across the state of Kentucky, three across the country (TN, UT, IN), and one international (Cali, Columbia). Served as team member gathering a variety of evidence about the quality of learning environments to highlight areas in which the school/district excels and areas that would be levers to utilize in the continuous improvement process to enhance student achievement.

- Diagnostic review team-Served as team member responsible for gathering data to analyze supportive evidence for targeted improvement priorities for schools identified CSI.

\section{SKILLS}

Strategic improvement planning and execution Educational staff supervision

Program development and management

Staff development
Performance assessments

Instructional leadership

Curriculum development

Building Effective Relationships 